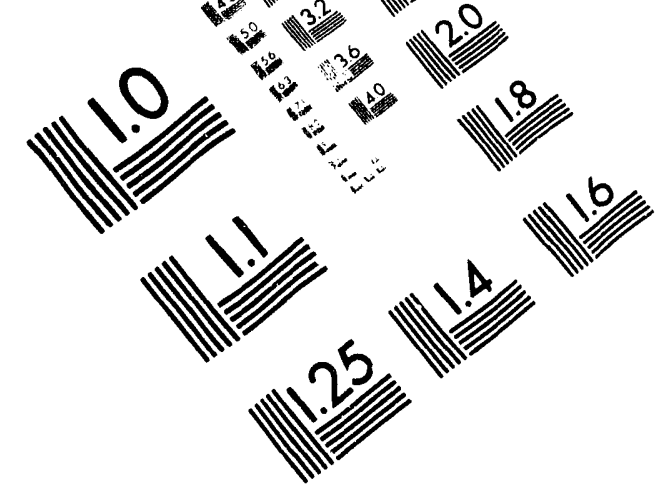

Association for Information and Image Management

1100 Wayne Avenue. Suite 1100

Silver Spring, Maryland 20910

$301 / 587-8202$

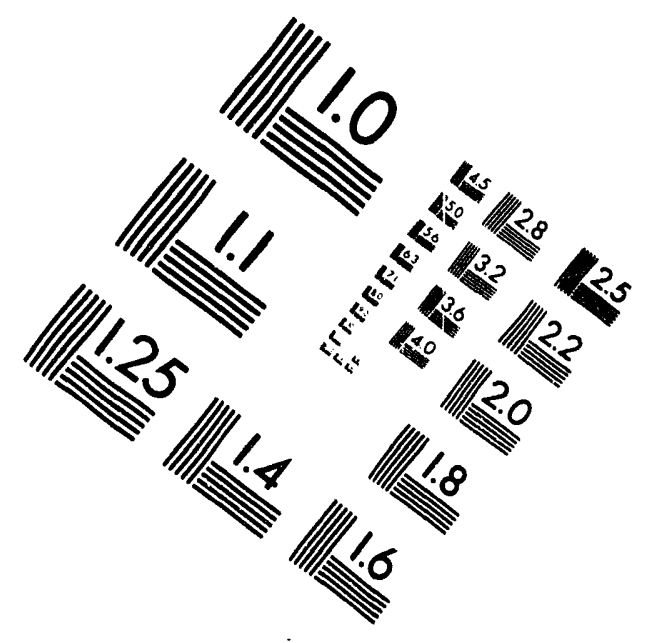

\title{
Centimeter
}

$\begin{array}{llllllllllllllll}1 & 2 & 3 & 4 & 5 & 6 & 7 & 8 & 9 & 10 & 11 & 12 & 13 & 14 & 15 & \mathrm{~mm}\end{array}$

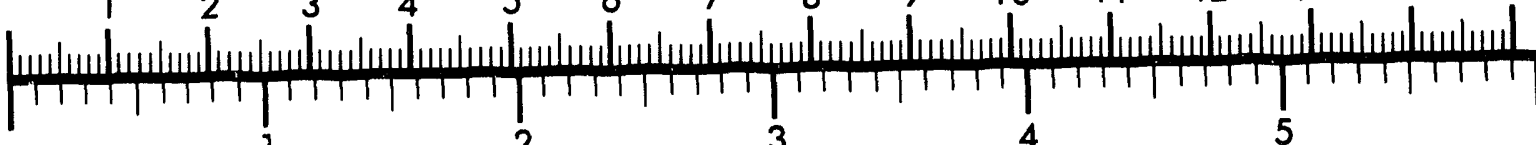
Inches

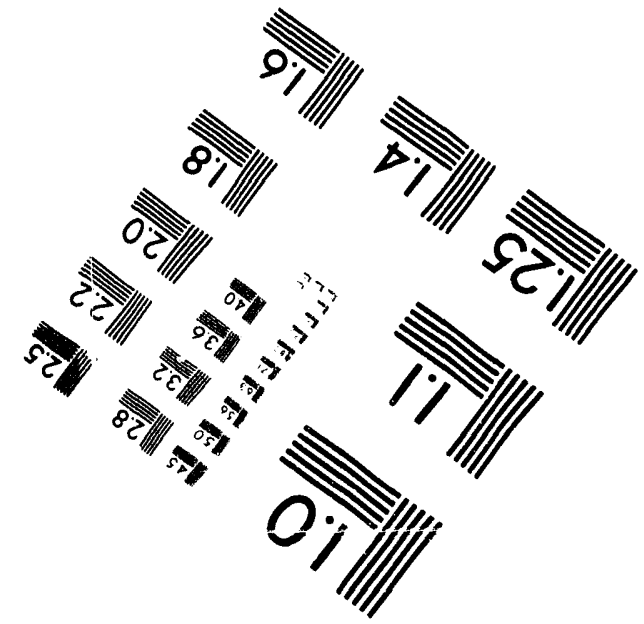

MANUFACTURED TO AIIM STANDARDS

BY APPLIED IMAGE. INC.

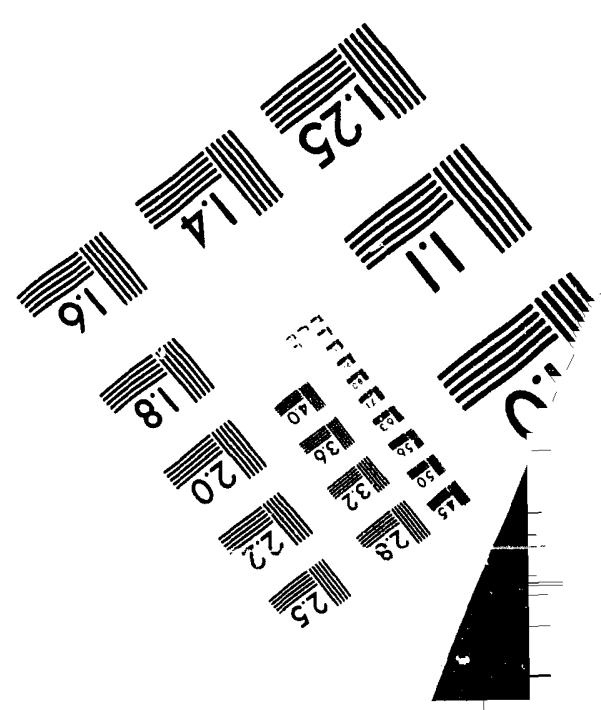



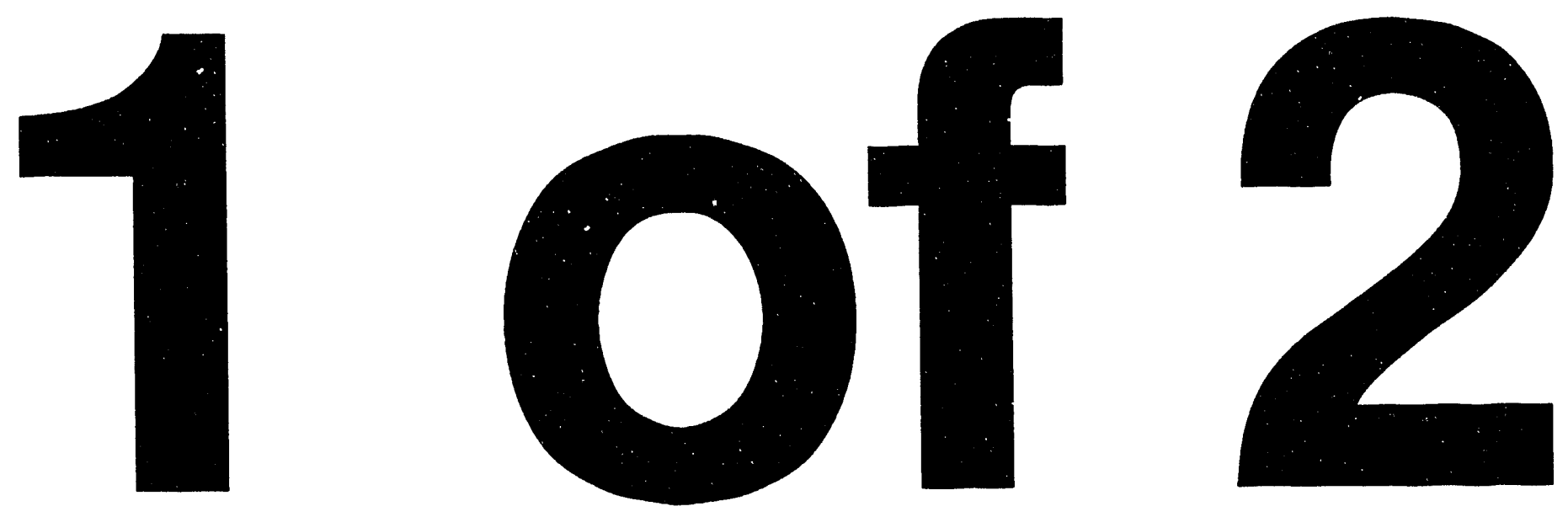
DOE/RL-90-49

Revision 0

\section{The 4843 Alkali Metal Storage Facility Closure Plan}

Engirworing drawings for who propect ara inamified as CAPE ...36 406 l. aquiries may he tiracted to:

Office of Scientific and

rechnical information

p. S. Fux 62

Cak Ridge. IN 37831 
STATE ENVIRONMENTAL POLICY ACT (SEPA)

CHECKLIST

FOR THE

4843 ALKALI METAL STORAGE FACILITY

REVISION 0

June 1991

WASHINGTON ADMINISTRATIVE CODE

ENVIRONMENTAL CHECKLIST FORMS

[WAC 197-11-960] 
SEPA ENVIRONMENTAL CHECKLIST

\section{A. BACKGROUND}

1. Name of proposed project:

The 4843 Alkali Metal Storage Facility (4843 AMSF) closure plan. This SEPA Checklist is being submitted concurrently with the 4843 AMSF closure plan. Information contained in this checklist pertains only to the 4843 AMSF. In the context of this document, 'site' refers to only the area covered by the physical structure of the unit.

2. Name of applicants:

U.S. Department of Energy-Richland Operations (DOE-RL); and Westinghouse Hanford Company (WHC)

3. Address and phone number of applicant and contact person:

U.S. Department of Energy

Richland Operations office

P.0. Box 550

Richland, Washington 99352

Contact Persons:

E. A. Bracken, Director

Environmental Restoration Division (509) 376-7277

4. Date checklist prepared:

June 1991

5. Agency requesting the checklist:

Washington State

Department of Ecology

Mail Stop PV-11

0lympia, WA 98504-8711

6. Proposed timing or schedule (including phasing, if applicable):

Construction of the 4843 AMSF (originally known as Building \#3) was completed in 1971. From 1971 to 1980, Building \#3 was used primarily as a tool shed. In 1980, Building \#3 was relocated to its current site and renamed Building 4722-E. From 1980 to 1986, Building 4722-E was used as construction support for the Fuels and Material Examination Facility. In 1986, Building 4722-E was renamed 4843 AMSF. The 4843 AMSF began receiving dangerous and mixed alkali metal waste in April 1986. The 4843 AMSF serves as a waste management unit for the storage of dangerous and mixed alkali metal waste. This material is regulated under the 
4843 SEPA Checklist Draft/Page 2 of 14

Resource Conservation and Recovery Act (RCRA) and by the Washington State Department of Ecology (Ecology) Dangerous Waste Regulations, Washington Administrative Code (WAC) Chapter 173-303.

Final closure activities will be completed and certified in accordance with the closure plan.

7. Do you have any plans for future additions, expansion, or further activity related to or connected with this proposal? If yes, explain.

No.

8. List any environmental information you know about that has been prepared, or will be prepared, directly related to this proposal.

- This SEPA Checklist is being submitted to Ecology and the U.S. Environmental Protection Agency (EPA) concurrently with the 4843 AMSF Closure Plan.

- A RCRA Part A Dangerous Waste Permit Application for the 4843 AMSF was submitted to Ecology in September 1987. Revision 1 of the Part A Permit Application was submitted in November 1987, and Revision 2 was submitted June 4, 1991 .

- A Hanford Site Facility (Sitewide) Part B Permit Application is being prepared that will contain information pertaining to the entire Hanford Site.

Additional environmental information on the Hanford Site, in general, can be found in the following references: (1) Final Environmental Impact Statement - Disposal of Hanford Defense High-Level, Transuranic and Tank Wastes, DOE/EIS-0113 (U.S. Department of Energy, 1987, Richland, Washington), (2) Hanford Site National Environmental Policy Act (NEPA) Characterization, PNL-6415 (Revision 2, Pacific Northwest Laboratory, 1990, Richland, Washington), and (3) Draft Environmental Impact Statement -Decommissioning of Eight Surplus Production Reactors at the Hanford Site, Richland, Washington, DOE/EIS-0119D (U.S. Department of Energy, 1989, Washington, D.C.).

9. Do you know whether applications are pending for government approvals of other proposals directly affecting property covered by your proposal? If yes, explain.

No other applications that would affect property associated with the 4843 AMSF are known to be pending government approval.

10. List any government approvals or permits that will be needed for your proposal, if known.

Ecology is the lead agency authorized to approve the closure $\mathrm{plan}$ for the 4843 AMSF pursuant to the requirements of the WAC 173-303-610. The closure plan also must receive approval from the EPA. Ecology also is the lead agency in issuing the Hanford Site Facility Part B Permit. 
4843 SEPA Checklist Draft/Page 3 of 14

11. Give a brief, complete description of your proposal, including the

12. Give the location of the proposal. Give sufficient information for a person to understand the precise location of the proposed project, including a street address, if any, and section, township, and range, if known. If a proposal would occur over a range of area, provide the range or boundaries of the site(s). Provide a legal description, site plan, vicinity map, and topographic map, if reasonably available.

The 4843 AMSF is located in the northwest portion of the 400 Area of the Hanford Site approximately 8 miles (12.9 kilometers) north of Richland, Washington. Maps and plans of the 400 Area are contained in the 4843 AMSF closure plan with which this SEPA Checklist is being submitted. The west end of the 4843 AMSF provides part of the fence surrounding the 400 Area laydown area. The 4843 AMSF is located in the SE $1 / 4$, NW $1 / 4$, SW $1 / 4$, Section 18, T11N, R28E. 


\section{B. ENVIRONMENTAL ELEMENTS}

1. Earth

a. General description of the site (indicate one): Flat, rolling, hilly, steep, mountainous, other.

Flat.

b. What is the steepest slope on the site (approximate percent slope)?

Two loading ramps extend down and away from the 4843 AMSF at a slope of approximately $1 / 2$ inch per foot (4 percent). The 1 and beneath the site is flat.

c. What general types of soils are found on the site (for example, clay, sand, gravel, peat, muck)? If you know the classification of agricultural soils, specify them and note any prime farmland.

The soil at the 4843 AMSF consists primarily of gravelly sands. No farming is permitted on the site.

d. Are there surface indications or history of unstable soils in the immediate vicinity? If so, describe.

No.

e. Describe the purpose, type, and approximate quantities of any filling or grading proposed. Indicate the source of the fill.

Does not apply.

f. Could erosion occur as a result of clearing, construction, or use? If so, generally describe.

Because of the flat topography, dry climate, and gravel surrounding the 4843 AMSF, large scale erosion is not expected. Minor erosion due to wind and/or precipitation could occasionally occur.

g. Approximately what percent of the site will be covered with impervious surfaces after project construction (for example, asphalt or buildings)?

Approximately 80 percent of the site is covered. No changes are planned.

h. Proposed measures to reduce or control erosion, or other impacts to the earth, if any?

Unpaved roadways and parking areas are covered with gravel to minimize wind erosion potential because of vehicular travel. No other erosion control methods are considered necessary. 
2. Air

a. What types of emissions to the air would result from the proposal (i.e., dust, automobile, odors, industrial wood smoke) during construction and when the project is completed? If any, generally describe and give approximate quantities if known.

Minor amounts of exhaust will be generated by vehicles used to gain access to the site. Small quantities of dust could be generated by decontamination and sampling activities.

b. Are there any offsite sources of emissions or odors that may affect your proposal? If so, generally describe.

No.

c. Proposed measures to reduce or control emissions or other impacts to the air, if any?

Standard work procedures and emission controls.

\section{Water}

a. Surface:

1) Is there any surface water body on or in the immediate vicinity of the site (including year-round and seasonal streams, saltwater, lakes, ponds, wetlands)? If yes, describe type and provide names. If appropriate, state what stream or river it flows into.

No.

2) Will the project require any work over, in, or adjacent to (within 200 feet) the described waters? If yes, please describe and attach available plans.

Does not apply.

3) Estimate the amount of $\mathrm{fill}$ and dredge material that would be placed in or removed from surface water or wetlands and indicate the area of the site that would be affected. Indicate the source of fill material.

None.

4) Will the proposal require surface water withdrawals or diversions? Give general description, purpose, and approximate quantities if known.

No. 
5) Does the proposal lie within a 100-year floodplain? If so, note location on the site plan.

No.

6) Does the proposal involve any discharges of waste materials to surface waters? If so, describe the type of waste and anticipated volume of discharge.

No.

b. Ground:

1) Will ground water be withdrawn, or will water be discharged to ground water? Give general description, purpose, and approximate quantities, if known.

No.

2) Describe waste materials that will be discharged into the ground from septic waste tanks or other sources, if any (for example: domestic sewage; industrial, containing the following

chemicals...; agricultural; etc.). Describe the general size of the system, the number of such systems, the number of houses to be served (if applicable), or the number of animals or humans the system(s) are expected to serve.

Does not apply.

c. Water Runoff (including storm water):

1) Describe the source of runoff (including storm water) and method of collection and disposal, if any (include quantities, if known). Where will this water flow? Will this water flow into other waters? If so, describe.

The Hanford Site receives 6 to 8 inches (15 to 20 centimeters) of annual precipitation. Any precipitation that occurs at the 4843 AMSF will flow away from the building and seep into the soil on and near the site. Because of the desert climate, the evaporation greatly exceeds precipitation, thus, zero recharge potential.

2) Could waste materials enter ground or surface waters? If so, generally describe.

No.

d. Proposed measures to reduce or control surface, ground, and runoff water impacts, if any:

All water used for cleaning and sampling activities will be collected and sent to an appropriate disposal unit on the Hanford Site. 
4. Plants

a. Check the types of vegetation found on the site:

deciduous tree: alder, maple, aspen, other

- evergreen tree: fir, ceder, pine, other

- shrubs

grass

pasture

crop or grain

wet soil plants: cattail, buttercup, bulrush, skunk cabbage, other

water plants: water lily, eelgrass, milfoil, other

$\bar{x}$ other types of vegetation

Tumbleweeds

b. What kind and amount of vegetation will be removed or altered? None.

c. List threatened or endangered species known to be on or near the site.

None. However, additional information concerning endangered and threatened plants on the Hanford Site can be found in the environmental documents referred to in the answer to Checklisi Question A.8.

d. Proposed landscaping, use of native plants, or other measures to preserve or enhance vegetation on the site, if any:

None.

\section{Animals}

a. Indicate any birds and animals which have been observed on or near the site or are known to be on or near the site:

birds: hawk, heron, eagle, songbirds, other mammals: deer, bear, elk, beaver, other

fish: bass, salmon, trout, herring, shellfish, other

A variety of insects, birds, and mammals common to the Hanford Site, including pigeons, songbirds, rodents, and hares, have been observed in the vicinity of the 4843 AMSF. Additional information on birds and animals on the Hanford Site can be found in the environmental documents referred to in the answer to Checklist Question A.8. 
b. List any threatened or endangered species known to be on or near the site.

None. However, additional information concerning endangered and threatened species on the Hanford Site can be found in the environmental documents referred to in the answer to Checklist Question A.8.

c. Is the site part of a migration route? If so, explain. The site is part of the region-wide Pacific flyway for waterfowl.

d. Proposed measures to preserve or enhance wildlife, if any: None.

\section{Energy and Natural Resources}

a. What kinds of energy (electric, natural gas, oil, wood stove, solar) will be used to meet the completed project's energy needs? Describe whether it will be used for heating, manufacturing, etc.

Electricity for lighting. Fuel and oil for vehicles and equipment.

b. Would your project affect the potential use of solar energy by adjacent properties? If so, generally describe.

No.

c. What kinds of energy conservation features are included in the plans of this proposal? List other proposed measures to reduce or control energy impacts, if any:

None.

\section{Environmental Health}

a. Are there any environmental health hazards, including exposure to toxic chemicals, risk of fire and explosion, spill, or hazardous waste, that could occur as a result of this proposal? If so, describe.

The 4843 AMSF will be cleaned by removing or decontaminating a11 dangerous waste and waste residues to appropriate action levels. All proper procedures will be followed during these operations to minimize exposure to dangerous waste.

1) Describe special emergency services that might be required.

Hanford Site security, fire response, ambulance services, and a trained and fully equipped Hazardous Material Team are on call at all times in the event of an onsite emergency. 
2) Proposed measures to reduce or control environmental health hazards, if any:

Environmental health hazards are expected to be minimal. Procedures to prevent and manage potential hazards are presented in the closure plan.

b. Noise

1) What types of noise exist in the area which may affect your project (for example: traffic, equipment, operation, other)?

None.

2) What types and levels of noise would be created by or associated with the project on a short-term or a long-term basis (for example: traffic, construction, operation, other)? Indicate what hours noise would come from the site.

Minor amounts of noise from traffic and equipment are expected on a short-term basis during day shift hours. The location of the 400 Area will prevent any detectable increase in noise levels off the Hanford Site.

3) Proposed measures to reduce or control noise impacts, if any:

Vehicles and equipment will meet manufacturer's requirements for noise suppression. Though not required, noise protection will be available for use at the employee's option.

\section{Land and Shoreline use}

a. What is the current use of the site and adjacent properties?

The 4843 AMSF is a part of the U.S. government-owned Hanford Site, which is used for the production of special nuclear materials and the management of waste associated with the production of those materials.

b. Has the site been used for agriculture? If so, describe.

No portion of the Hanford Site, including the site of the 4843 AMSF, has been used for agricultural purposes since 1943.

c. Describe any structures on the site.

The 4843 AMSF is a single floor structure, on a concrete slab, assembled with an all steel structural frame, roof, and sides. Occupying an area of approximately 1,613 square feet (150 square meters), the building is an open area divided in half by a rope. There are no offices or rest rooms inside the 4843 AMSF. Concrete block shielding exists along the north wall. Access to the building 
is provided by two large roll-up doors in the east and west ends and personnel doors in the southeast and northwest corners of the building.

d. Will any structures be demolished? If so, what?

No. This facility will be used as a storage unit for alkali metal product.

e. What is the current zoning classification of the site?

The Hanford Site is zoned by Benton County as an unclassified use district.

f. What is the current comprehensive plan designation of the site?

The 1985 Benton County Comprehensive Land Use Plan designates the Hanford Site as the "Hanford Reservation." Under this designation, land on the Hanford Site can be used for "activities nuclear in nature." Nonnuclear activities are authorized "if and when DOE approval for such activities is obtained."

g. If applicable, what is the current shoreline master program designation of the site?

Does not apply.

h. Has any part of the site been classified as an "environmentally sensitive" area? If so, specify.

No.

i. Approximately how many people would reside or work in the completed project?

No people will reside in the 4843 AMSF. A limited number of employees will be assigned to work in the 4843 AMSF during closure activities.

j. Approximately how many people would the completed project displace? None.

k. Proposed measures to avoid or reduce displacement impacts, if any: Does not apply.

1. Proposed measures to ensure the proposal is compatible with existing and projected land uses and plans, if any:

Does not apply. (Refer to Checklist Question B.8.f.) 
9. Housing

a. Approximately how many units would be provided, if anj? Indicate whether high-, middle-, or low-income housing.

None.

b. Approximately how many units, if any, would be eliminated? Indicate whether high-, middle-, or low-income housing.

None.

c. Proposed measures to reduce or control housing impacts, if any: Does not apply.

10. Aesthetics

a. What is the tallest height of any proposed structure(s), not including antennas; what is the principal exterior building material(s) proposed?

The existing 4843 AMSF has a total height of approximately 20 feet ( 6.1 meters). The building exterior walls and roof are steel. No new building construction is planned.

b. What views in the immediate vicinity would be altered or obstructed? None.

c. Proposed measures to reduce or control aesthetic impacts, if any: None.

11. Light and Glare

a. What type of light or glare will the proposal produce? What time of day would it mainly occur?

None.

b. Could light or glare from the finished project be a safety hazard or interfere with views?

No.

c. What existing offsite sources of light or glare may affect your proposal?

None. 
4843 SEPA Checklist Draft/Page 12 of 14

d. Proposed measures to reduce or control light and glare impacts, if any:

Does not apply.

12. Recreation

a. What designated and informal recreational opportunities are in the immediate vicinity?

None.

b. Would the proposed project displace any existing recreational uses? If so, describe.

Does not apply.

c. Proposed measures to reduce or control impacts on recreation, including recreation opportunities to be provided by the project or applicant, if any?

Does not apply.

\section{Historic and Cultural Preservation}

a. Are there any places or objects listed on, or proposed for, national, state, or local preservation registers known to be on or next to the site? If so, generally describe.

No places or objects listed on, or proposed for, national, state, or local preservation registers are known to be on or next to the 4843 AMSF. Additional information on the Hanford Site environment can be found in the environmental documents referred to in the answer to Checklist Question A.8.

b. Generally describe any landmarks or evidence of historic, archaeological, scientific, or cultural importance known to be on or next to the site.

There are no known archaeological, historical, or native American religious sites at or next to the 4843 AMSF. Additional information on the Hanford Site environment can be found in the environmental documents referred to in the answer to Checklist Question A.8.

c. Proposed measures to reduce or control impacts, if any:

No impacts are anticipated. Where appropriate, a cultural resource review will provide the vehicle for necessary approvals required under the National Historic Preservation Act. 
4843 SEPA Checklist

Draft/Page 13 of 14

\section{Transportation}

a. Identify public streets and highways serving the site, and describe proposed access to the existing street system. Show on site plans, if any.

Does not apply.

b. Is site currently served by public transit? If not, what is the approximate distance to the nearest transit stop?

The site is not publicly accessible, and, therefore, is not served by public transportation.

c. How many parking spaces would the completed project have? How many would the project eliminate?

This project does not affect parking spaces.

d. Will the proposal require any new roads or streets, or improvements to existing roads or streets, not including driveways? If so, generally describe (indicate whether public or private).

No.

e. Will the project use (or occur in the immediate vicinity of) water, rail, or air transportation? If so, generally describe.

No.

f. How many vehicular trips per day would be generated by the completed project? If known, indicate when peak volumes would occur.

When the building is used for product storage, approximately one trip each week will be made to the building.

g. Proposed measures to reduce or control transportation impacts, if any:

Impact will be minimized by taking multipurpose trips with several stops.

\section{Public Services}

a. Would the project result in an increased need for public services (for example: fire protection, police protection, health care, schools, other)? If so, generally describe.

No.

b. Proposed measures to reduce or control direct impacts on public services, if any:

Does not apply. 


\section{Utilities}

a. List utilities currently available at the site (electricity, natural gas, water, refuse service, telephone, sanitary sewer, septic system, other):

Electricity is the only utility currently available at the 4843 AMSF. Portable radios are carried by personnel accessing the 4843 AMSF, and a telephone is located approximately 100 feet ( 30.5 meters) west of the 4843 AMSF.

b. Describe the utilities that are proposed for the project, the utility providing the service, and the general construction activities on the site or in the immediate vicinity which might be needed.

No new utilities or general construction activities are proposed.

\section{SIGNATURES}

The above answers are true and complete to the best of my knowledge. I understand that the lead agency is relying on them to make its decision.

E. A. Bracken, Director

Environmental Restoration Division

U.S. Department of Energy

Richland Operations Office

QE Lerch

R. E. Lerch, Manager

Environmental Division

Westinghouse Hanford Company
Date

$$
6-7-91
$$

Date 
DOE/RL-90-49

Revision 0

UC- 630,721

\section{The 4843 Alkali Metal Storage Facility Closure Plan}

Date Published

June 1991
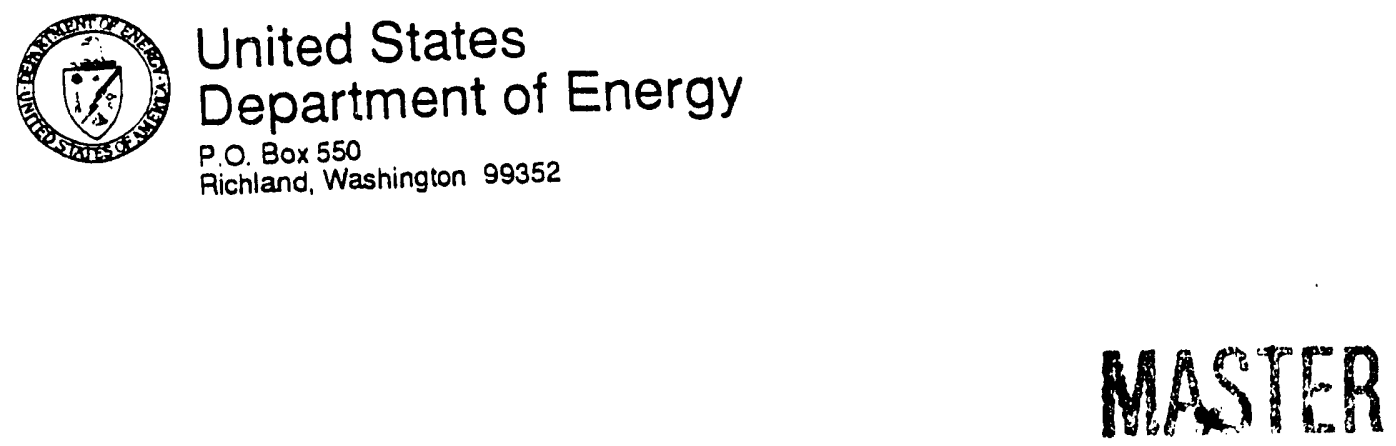

Approved for Public Release 


\section{TRADEMARK DISCLAIMER}

Reference herein to any specific commercial product, process, or service by trade name, trademark, manufacturer, or otherwise, does nol necessarily constitute or imply its endorsement, recommendation, or favoring by the United States Government or any agency thereof or its contractors or subcontractors.

This report has been reproduced from the best available copy. Available in paper copy and microfiche.

Available to the U.S. Department of Energy

and its contractors from

Office of Scientific and Technical Information

P.0. Box 62

Oak Ridge, TN 37831

(615) 576.8401

Available to the public from the U.S. Department of Commerce National Technical information Service

5285 Port Royal Road

Springfield. VA 22161

(703) 487.4650

Printed in the United States of America 
$\mathrm{DOE} / \mathrm{RL}-90-49$

Revision 0

PART A PERMIT APPLICATION ................ A . .

1.0 INTRODUCTION ........................ . . . .

1.1 EXECUTIVE SUMMARY ....... 1-1

1.2 THE 4843 ALKALI METAL STORAGE FACILITY CLOSURE

PLAN CONTENTS . . . . . . . . . . . . . 1-1

1.2.1 Facility Description ............. 1-2

1.2 .2 Process Information ......................

1.2.3 Waste Characteristics ........... 1-2

1.2 .4 Groundwater Monitoring ........... 1-2

1.2.5 Closure Strategy and Performance Standards ..... 1-2

1.2 .6 Closure Activities .............. 1-3

1.2 .7 Postclosure ............... . . 1-3

1.2 .8 References .............. 1-3

2.0 FACILITY DESCRIPTION . . . . . . . . . . . . . . 2-1

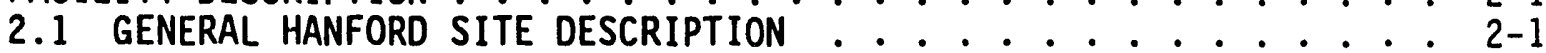

2.1.1 Permitting History ............ 2-1

2.2 FACILITY DESCRIPTION AND OPERATIONS ........... 2-2

2.3 SECURITY . . . . . . . . . . . . . . 2-2

2.3.1 24-Hour Surveillance System . . . . . . . . 2-3

2.3.2 Barrier and Means to Control Entry ....... 2-3

3.0 PROCESS INFORMATION ....................... 3- .

3.1 DESCRIPTION OF CONTAINERS .............. 3-1

3.2 CONTAINER MANAGEMENT PRACTICES $\ldots \ldots$

3.3 MANAGEMENT OF INCOMPATIBLE WASTE IN CONTAINERS $\ldots \ldots$

4.0 WASTE CHARACTERISTICS ................... . . . . .

4.1 ESTIMATE OF MAXIMUM INVENTORY OF WASTE ....... $4-1$

4.2 WASTE STORED AT THE 4843 ALKALI METAL STORAGE FACILITY . . . . 4-1

5.0 GROUNDWATER MONITORING . . . . . . . . . . . . 5-1

6.0 CLOSURE STRATEGY AND PERFORMANCE STANDARDS . . . . . . . . . 6-1

6.1 GENERAL CLOSURE STRATEGY .............. . . 6-1

6.2 GENERAL CLOSURE PROCEDURE . . . . . . . . . . 6-2

6.3 MINIMIZE THE NEED FOR FURTHER MAINTENANCE ........ $6-2$

6.4 PROTECTION OF HUMAN HEALTH AND THE ENVIRONMENT ....... $6-3$

6.5 RETURN LAND TO THE APPEARANCE AND USE OF SURROUNDINGS $\ldots . .6-3$

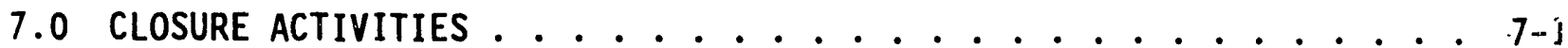

7.1 INTRODUCTION ................... . . . . . .

7.2 REMOVAL OF DANGEROUS WASTE INVENTORY $\ldots \ldots$

7.3 FACILITY SAMPLING . . . . . .

7.3.1 Decontamination of Building Equipment...... $7 \ldots 2$

7.3.2 Sampling and Verification of the Walls ...... $7-3$

7.3.3 Sampling and Verification of Concrete Floor..... 


\section{CONTENTS (cont)}

7.3.4 Decontamination of Equipment Used for Closure . . . . 7-4 7.3.5 Sampling Container Decontamination Procedures . . . . . 7-5 7.3.6 Quality Assurance and Quality Control Procedures . . 7-5 7.3.7 Reporting................... 7-6 7.3.8 Evaluation of Data . . . . . . . . . . . . . 7-6 7.3.9 Sampling Equipment, Container, and Preservation ... 7-7 7.3.10 Site Safety. . . . . . . . . . . . . . 7-7 7.4 DECONTAMINATION AND DISPOSAL OF BUILDING AND CONCRETE PAD . . 7-9 7.5 SCHEDULE FOR CLOSURE .................. . . $7-9$ 7.6 AMENDMENT OF PLAN . . . . . . . . . . . . . . . . . . . . . 7-9

7.7 CERTIFICATION OF CLOSURE . . . . . . . . . . . . . . . 7-10

8.0 POSTCLOSURE . . . . . . . . . . . . . . . . . . 8-1

8.1 NOTICE IN DEED BOOK . . . . . . . . . . . . . . . . 8-1

8.2 POSTCLOSURE CARE .................. 8-2

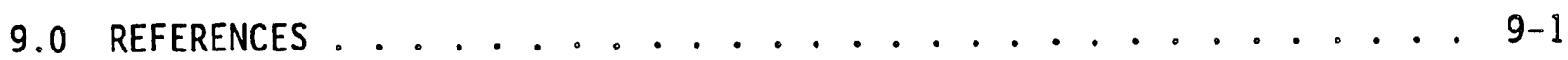

\section{APPENDICES}

A HANFORD SITE MAP .................... . . APP A-i

B DESIGN DRAWINGS .................... APP B-

C CURRENT WASTE INVENTORY .................... APP C-i

D SPILL REPORTS ..................... APP D-i

E PHOTOGRAPHS ...................... APP E-

F PERSONNEL TRAINING ................... APP F-i

G QUALITY ASSURANCE PROJECT PLAN FOR SAMPLING AT THE 4843 ALKALI METAL STORAGE FACILITY . . . . . . . . . . . . . APP G-i 


\section{FIGURES}

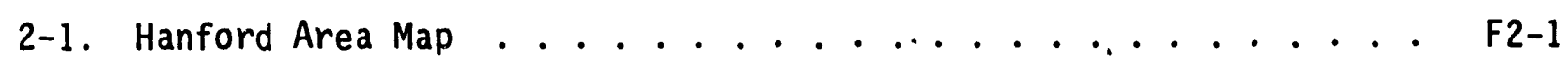

2-2. The 400 Area Map Showing Location of the 4843 Alkali

Metal Storage Facility................ . . F2-2

2-3. Floor Plan of the 4843 Alkali Metal Storage Facility . . . . F2-3

7-1. Sampling Flow Path . . . . . . . . . . . . . . . F7-1

7-2. Floor Sampling Locations . . . . . . . . . . . . . . F7-2

7-3. Schedule of Closure Activities . . . . . . . . . . . . F7-3

7-4. Closure Certification for the 4843 AMSF . . . . . . . . . . . F7-4

\section{TABLES}

3-1. Common Containers Stored at the 4843 Alkali Metal Storage Facility ................ . . . T3-1

7-1. The 4843 Alkali Metal Storage Facility Sampling Locations . . . . T7-1 7-2. Company-General Training Matrix . . . . . . . . . . . T7-2 


\section{LIST OF TERMS}

4843 AMSF

CERCLA

CFR

DOE

DOE-RL

DOT

Ecology

EII

EPA

HASP

HEIS

ICP-AES

M\&TE

OSHA

OSM

$Q A / Q C$

QAPI

QAPP

QI

QR

RCRA

RFI/CMS

$\mathrm{RI} / \mathrm{FS}$

RPD

TSD

WAC

Westinghouse Hanford

\section{Alkali Metal Storage Facility}

Comprehensive Environmental Response, Compensation, and Liability Act of 1980

Code of Federal Regulations

U.S. Department of Energy

U.S. Department of Energy-Richland Operations Office

U.S. Department of Transportation

Washington State Department of Ecology

Environmental Investigations Instructions

U.S. Environmental Protection Agency

health and safety plan

Hanford Environmental Information System

inductively coupled plasma/atomic emission spectroscopy

measure and test equipment

Occupational Safety and Health Administration

Office of Sample Management

quality assurance and quality control

quality assurance program index

quality assurance project plan

quality instruction

quality requirements

Resource Conservation and Recovery Act of 1976

RCRA facility investigation and corrective measures study remedial investigation/feasibility

relative percent different

treatment, storage, and/or disposal

Washington Administrative Code

Westinghouse Hanford Company 
DOE/RL-90-49

Revision 0

\section{PART A PERMIT APPLICATION}

As a result of storing dangerous waste, a Resource Conservation and Recovery Act of 1976 (RCRA) Part A permit application was submitted to the Washington State Department of Ecology (Ecology) in November 1987. The Part A, Form 1, for the Hanford Facility was submitted to Ecology in November 1987.

The original Part A, Form 3 (Revision 0), for the 4843 Alkali Metal Storage Facility was submitted to Ecology in September 1987 . Revision 0 contained only the U.S. Department of Energy-Richland Operations Office certification signature.

Revision 1 of the RCRA Part A Permit Application, Form 3, was prepared to designate Westinghouse Hanford Company as a 'co-operator' of the 4843 Alkali Metal Storage Facility to correspond to its signatory designation on the permit application; the U.S. Department of Energy-Richland Operations Office is designated as the owner/operator of the 4843 Alkali Metal Storage Facility. Revision 1 also was prepared to ensure that agreement between waste types and annual waste quantities as identified in the Part A, Form 3 (Revision 0 ), and the Hanford Site Annual Dangerous Waste Report submitted in May 1988 to Ecology.

The Part A, Form 3 (Revision 2), included here, contains four additional dangerous waste codes: D001 - Ignitability, D002 - Corrosivity, WTO1 - Extremely Hazardous Waste, and WTO2 - Dangerous Waste (if less than 4 pounds), and updates of other descriptive information. In addition, new interior photographs and an additional figure have been added to more accurately describe the 4843 Alkali Metal Storage Facility. Revision 2 included in this permit application consists of 11 pages of Form 3, 3 figures, and 3 photographs. 
DOE/RL-90-49

Revision 0

1
2
3
4
5

This page intentionally left blank. 


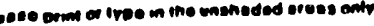

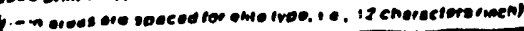

\section{FIRST OR REVISED APPLICATION}

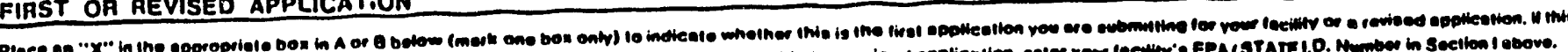

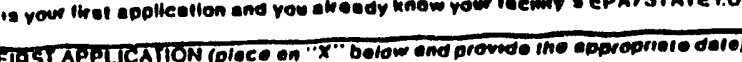

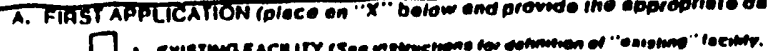

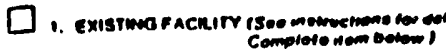

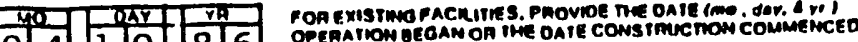

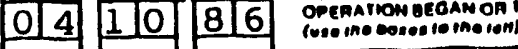

coamerness

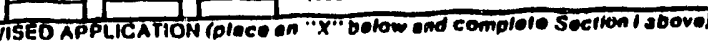

Q I. fackitr has an mieama status meammi

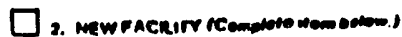

ronnerw rackums.

(mo. ony. or topena.

nowiezcinonis

exrectep ro ezon

PROCESSES - CODES AND DESIGN CAPACITIES

A. PHock

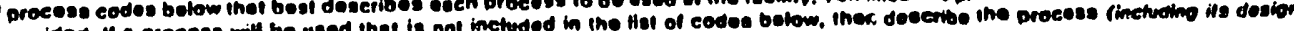
lines are needed. enter line code(0) in ino spece prove

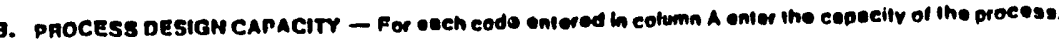

1. AMOUNT - Entee the amoum.

r. AMOUNT - Eniet the rmoum. 2. UNIT OF MEASUAE - Fooloch anould be usod.

PMO. APPAOPAIATE UNITS OF cESS MEASUNE FOA PROCESS

\section{Slorege:} DESION CAPACITY

WASTE PRE

INJECTION WELL
CONTAINER (boirel, dium, ole.)

TANK

SUAFACE MMPOUNDMENT

Olopoes:

LANDFILL

SO1 GALLONS OA LITERS
SO2 GALLNS ONLITEAS

CUBIC YAADS OR

CUBIC METENS

so4 GALLONS OA LITENS

Gaclons opcireas

LAND ARPLICATION
OCEAN DISPOSAL

SUAFACE IMPOUNOMENT

Umi OF MEASUnE

Gaclons ...

curens raioos

CUACG MA IERS.
OBO OALLONS OR LITEAS

DB 1 ACAF.FEET line rowno ino

depin ol ono hood)

aCRES OA HECTAAES

GALLONS OA LITEAS
ON HECTARE.METEA

OALLONS PEA DAY

mocess
Trootmont:

TANK

SURFACE IMPOUNOMENT

INCINEAATOR

OTHER (Use lor phy sienl, ehomueal.

Inermal or brobores liverment

processes nol oceuring in lenks.

surt see impoundments of metmer.

olors. Describe ine procesenes in.
APPROPAIATE UNITS OF MEPSURE FOR PROCESS cess MEASUEON CAPACITY

coo DESIGN CAPACITY

EXAMPLE FOR COMPLETING SECTION III (shown in line numbers $X .1$ and $X \cdot 2$ below): $A$ lacilily has lwo slorage lanks. one lank can hold 200 gallons ond the oiner can hold 400 gallons. The lacilily also has an incinerator that can burn up lo 20 gallons per hour.

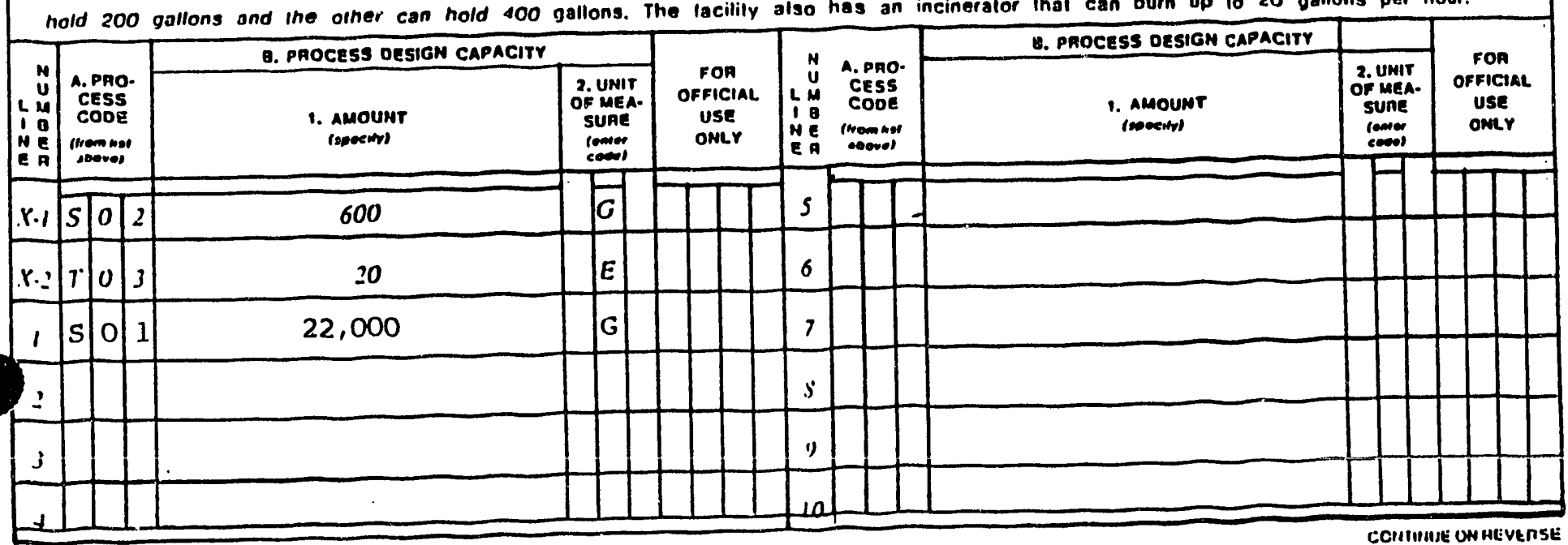

TO1 GALLONS PEA OAY OA

ITEAS PER OAY

IONS PEN HOUA OP GALLONS PEA HOUA OA

cacLons pEg paY on LITEAS PEP DAY
TO2 LITEAS PEA DAY METPIC TONS PEA HOUA

\begin{tabular}{|c|c|}
\hline UMT OF MEASURE & $\begin{array}{l}\text { mesune } \\
\text { cooe }\end{array}$ \\
\hline 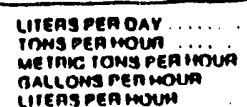 & 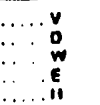 \\
\hline
\end{tabular}

umir of measune

ACAL.reEt

acme.reer
PAGE : OF 5 
sumuned hom ine trom.

iII. PROCesses (ronimwed)

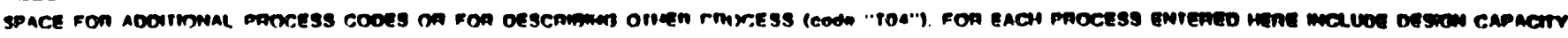
$\underline{\mathrm{SO}}$

The 4843 Alkali Metal Storage Facility (4843 AMSF) is used for the storage of alkali metal waste generated from, the Fast Flux Test Facility and from various other operations on the Hanford site that use alkali metals.

The 4843 AMSF currently houses dangerous and mixed alkali metal waste. The dangerous alkali metal waste storage area is separated from the mixed alkall metal storage area by a rope divider. The use of concrete blocks inside the 4843 AMSF provides shielding to protect the environment from radioactive alkali metal waste. Haste storage containers may include steel 5-, 30-, and 55-gallon drums, or sealed piping and sealed components that have been weided $c^{\prime}$ osed. The estimated annual quantity of waste has been calculated using design conditions for a maximum storage of 22,000 gallons (185,000 pounds) of alkalf metal waste. The 4843 AMSF does not presently contain the estimated quantity; however, there is potential for additional waste to be stored.

\section{I\%. DESCAIPTION OF DANGEROUS WASTES}

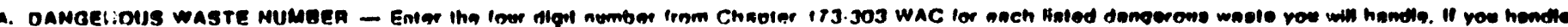

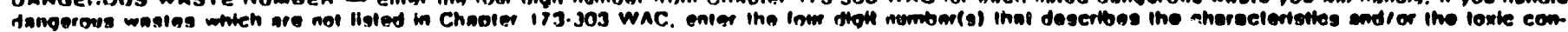
ienmennis of those damperous wastes.

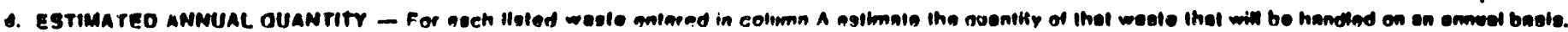

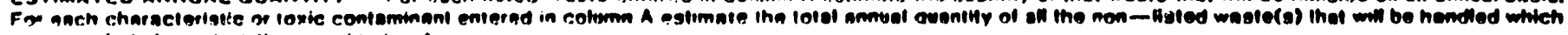

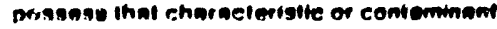

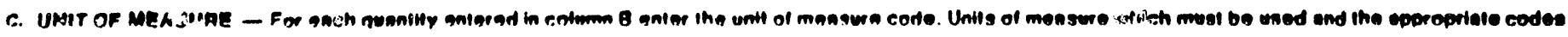
ars:

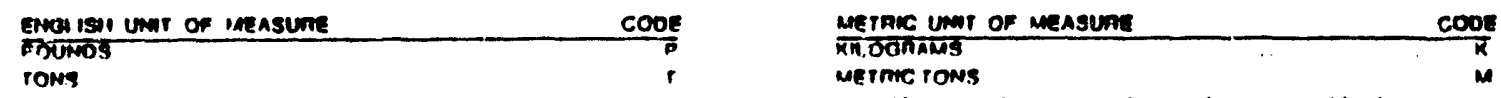

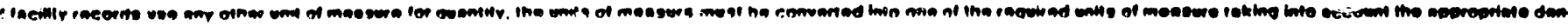

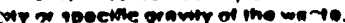

0. pwocesses

- mocess cooes

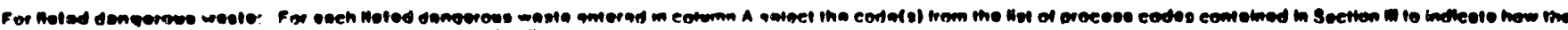

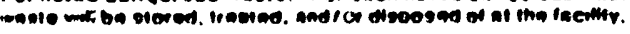

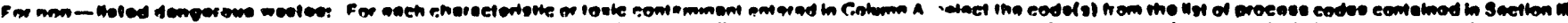

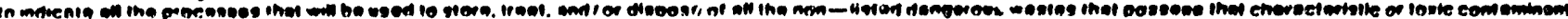

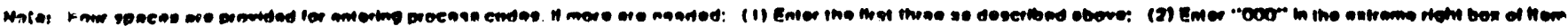

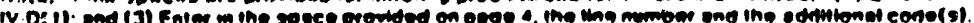

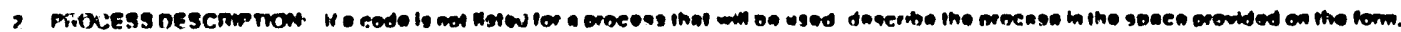

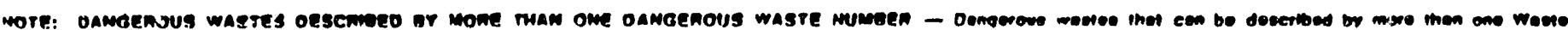

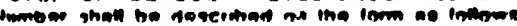

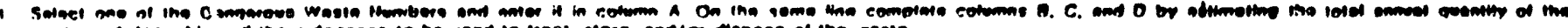

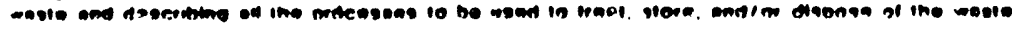

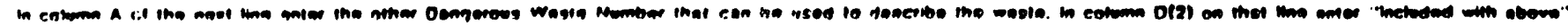

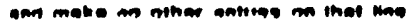

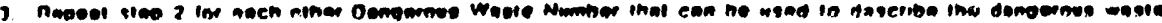

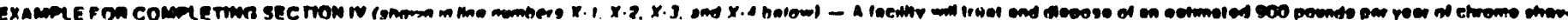

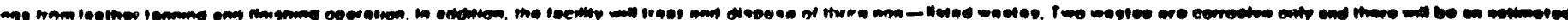

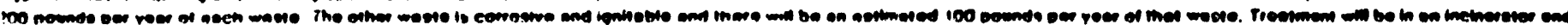

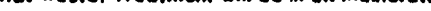

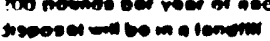

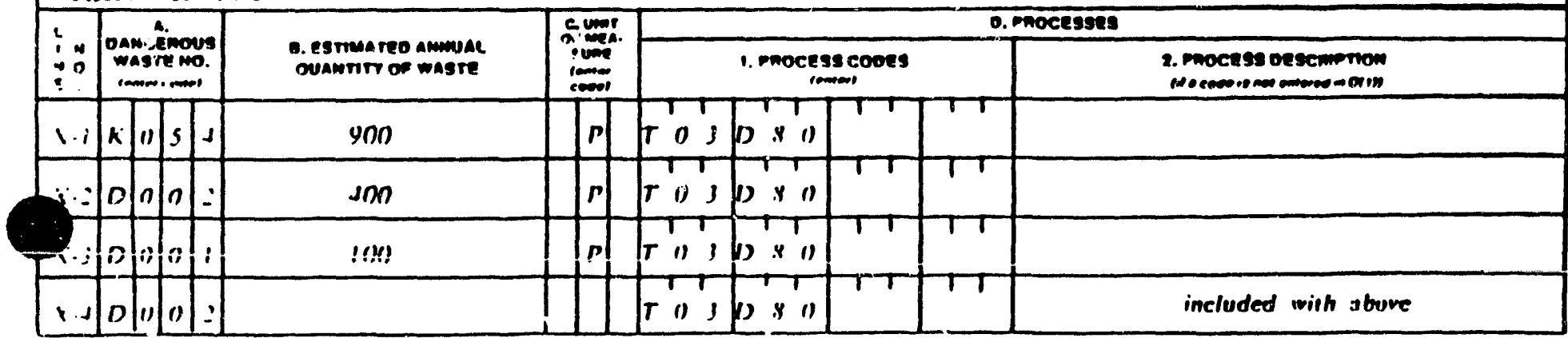

ate ir. ecrosasiems

PAGE 2 OF 5

contrme Onpages 
4843 Alkali Metal Storage Facility Rev. 2, 05-31-91, Page 3 of 11

Conimed nom poee 2.

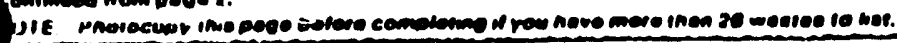

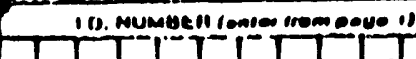

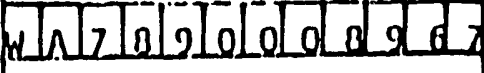

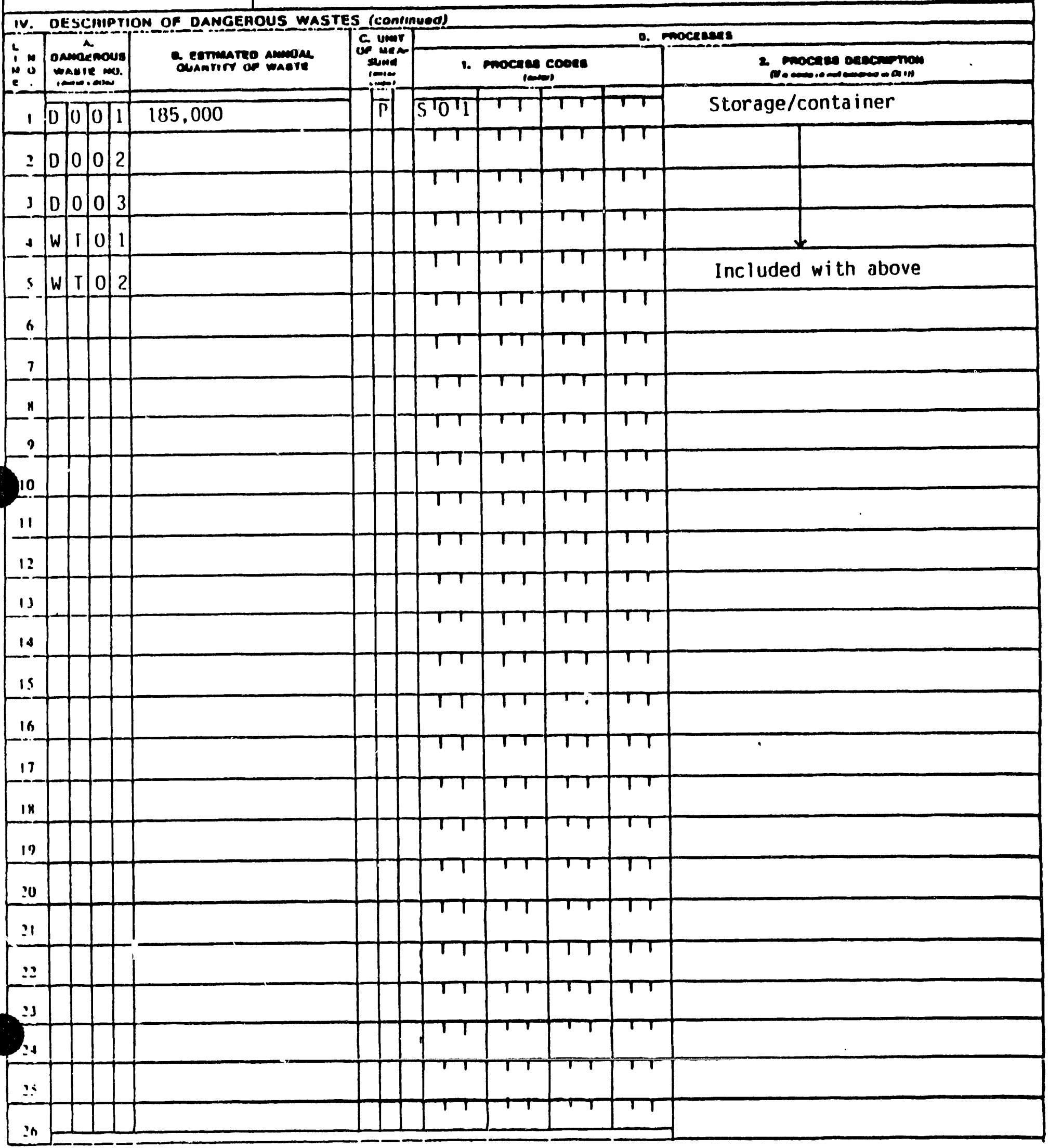

eri in in ecrosnilporms 
IV. DESCRIPTION OF DANGEROUS WASTES (cunlinuEd)

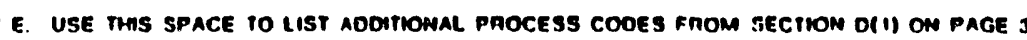

The 4843 AMSF is a storage unit for alkali metal waste that exhibits the dangerous waste characteristics of ignitability (D001), corrosivity (D002), reactivity (D003), and state-only waste.[Extremely. Hazardous Waste (WTO1) and Dangerous (WTO2)]. A maximum of 22,000 gallons (185,000 pounds) of dangerous and mixed alkall metal waste may be stored at the 4843 AMSF. Section IV. B. represents the total amount of alkali metal waste that potentially may be stored in this waste management unit.

V. FACILITY DRAWING

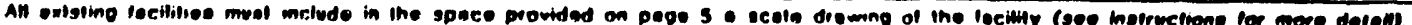
VI. PHOTOGRAPHS

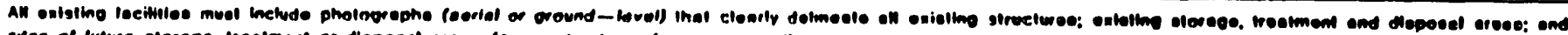

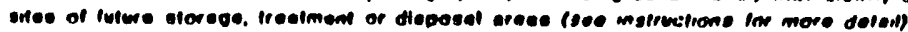

YII. FACILITY GEOGAAPHIC LOCATION This information is provided on the attached drawings and pliotos

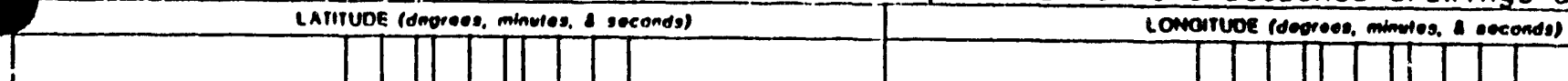

\section{F:ACILITY OWNER}

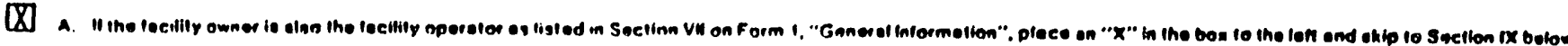

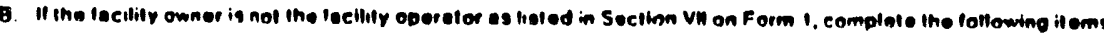

IX. OWNER CEATIFICATION

IX. OWNER CEATIFICATION

I cerlify under penally of law that I hove personally examined and am familiar with the informalion submilfed in this and all alloched documents. and thal besed on my inquiry of those individuals immedintely responsible lor obleining ihe intormation, i believe that the submilted information is true. accurate. and complete. I om aware that there are signilicant penallies lor submilling lalse inlormation. including the possibility of fine and imprisonment.

Name (pomi or irpa) John D. Wagoner

Manager, Richland Operations

United States Department. of Fnerax

$x$. OPEAATOR CEATIFICATION

I cerlily under penally of law that I have personbly examined and am lamiliar wilh the intormation submilted in this and all attached documents. and that besed on my inquiry of those individuals immedialely responsible for oblainino thi: intormation. I belisve that ine submilled informalion is lrue. accurale, and complete. I am oware that there are signilicent penallies lor submillino lalse information. including the possibilily of fine and imprisonment. 
4843 Alkali Metal Storage Facility Rev. 2, 05-31-91, Page 5 of 11

\section{OPERATOR CERTIFICATION}

I certify under penalty of law that I have personally examined and am familiar with the information submitted in this and all attached documents, and that based on my inquiry of those individuals immediately responsible for obtaining the information, I believe that the submitted information is true, accurate, and complete. I am aware that there are significant penalties for submitting false information including the possibility of fine and imprisonment.

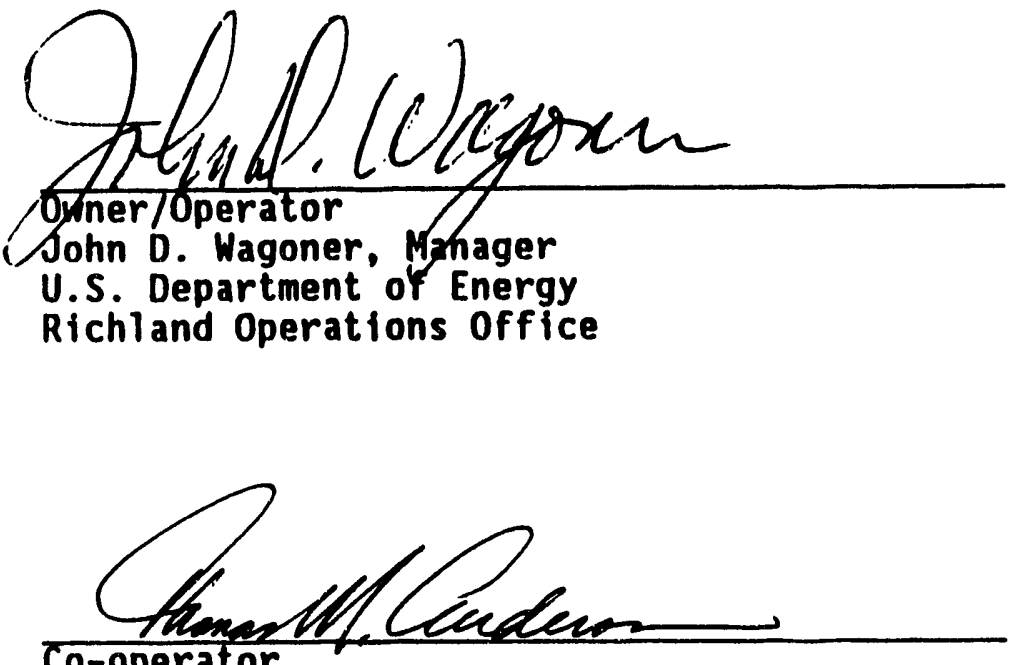

Co-operator

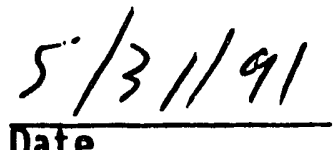

Thomas M. Anderson, President

Date

Westinghouse Hanford Company 


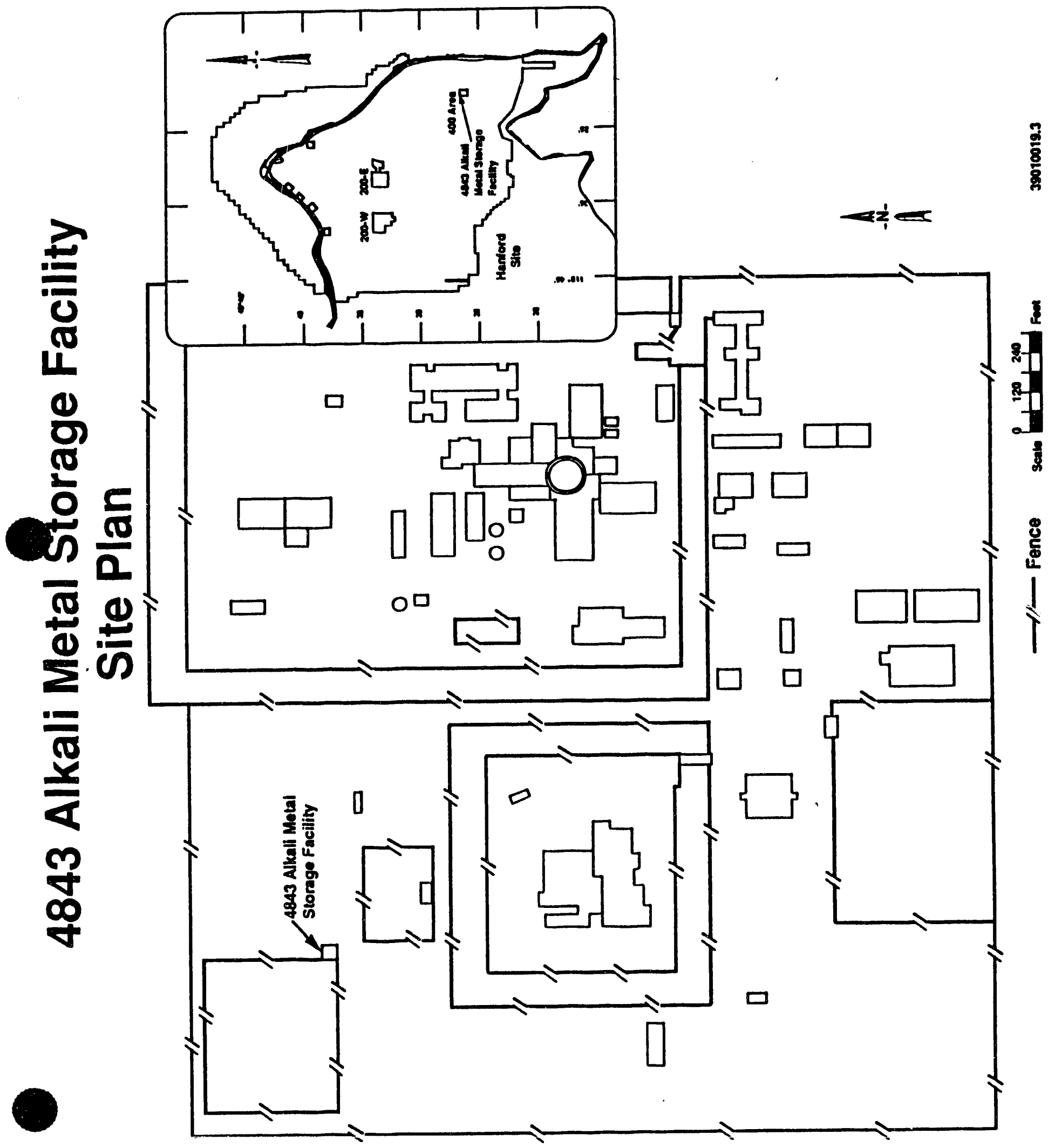


4843 Alkali Metal Storage Facility Rev. 2, 05-31-91, Page 7 of 11

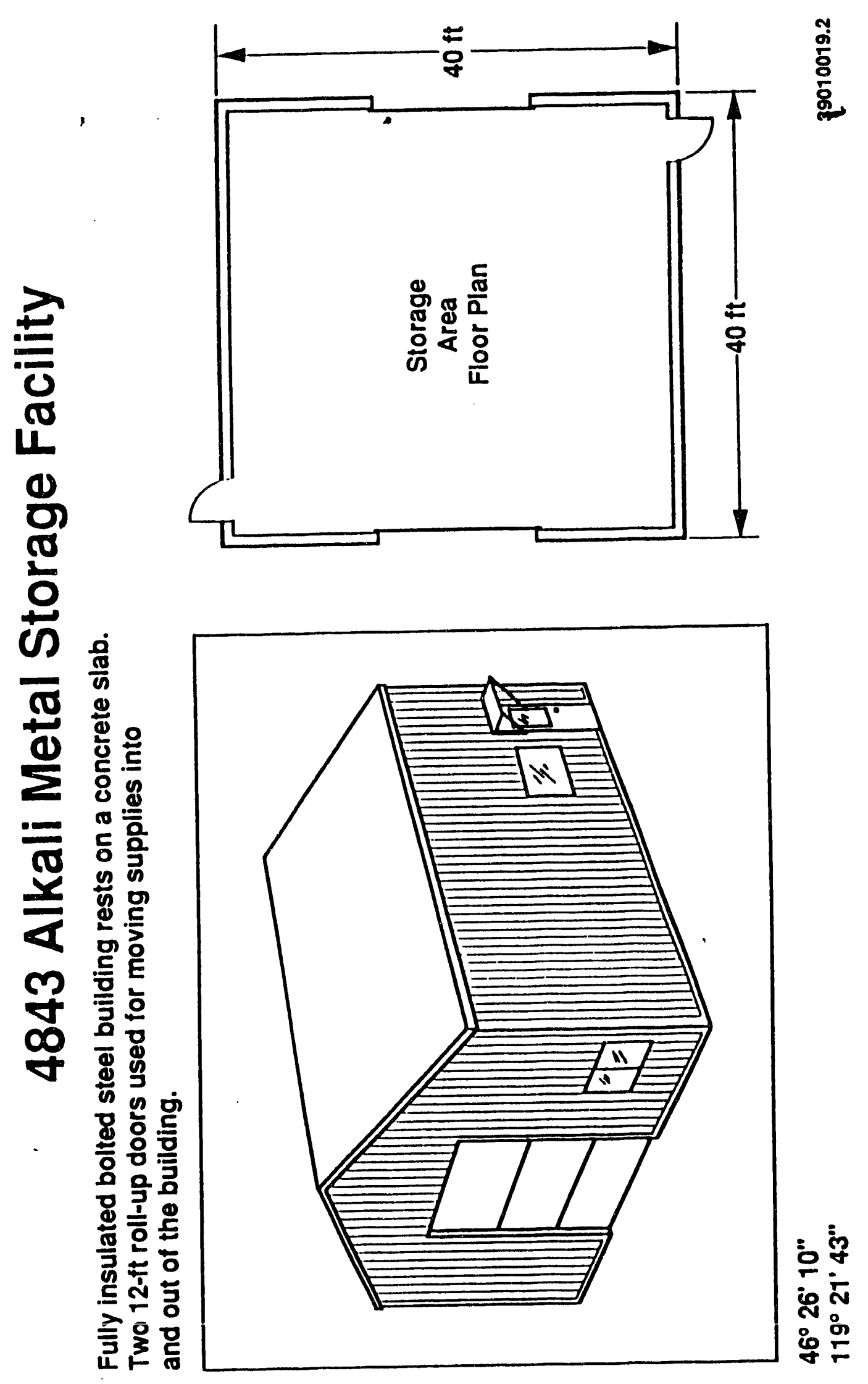




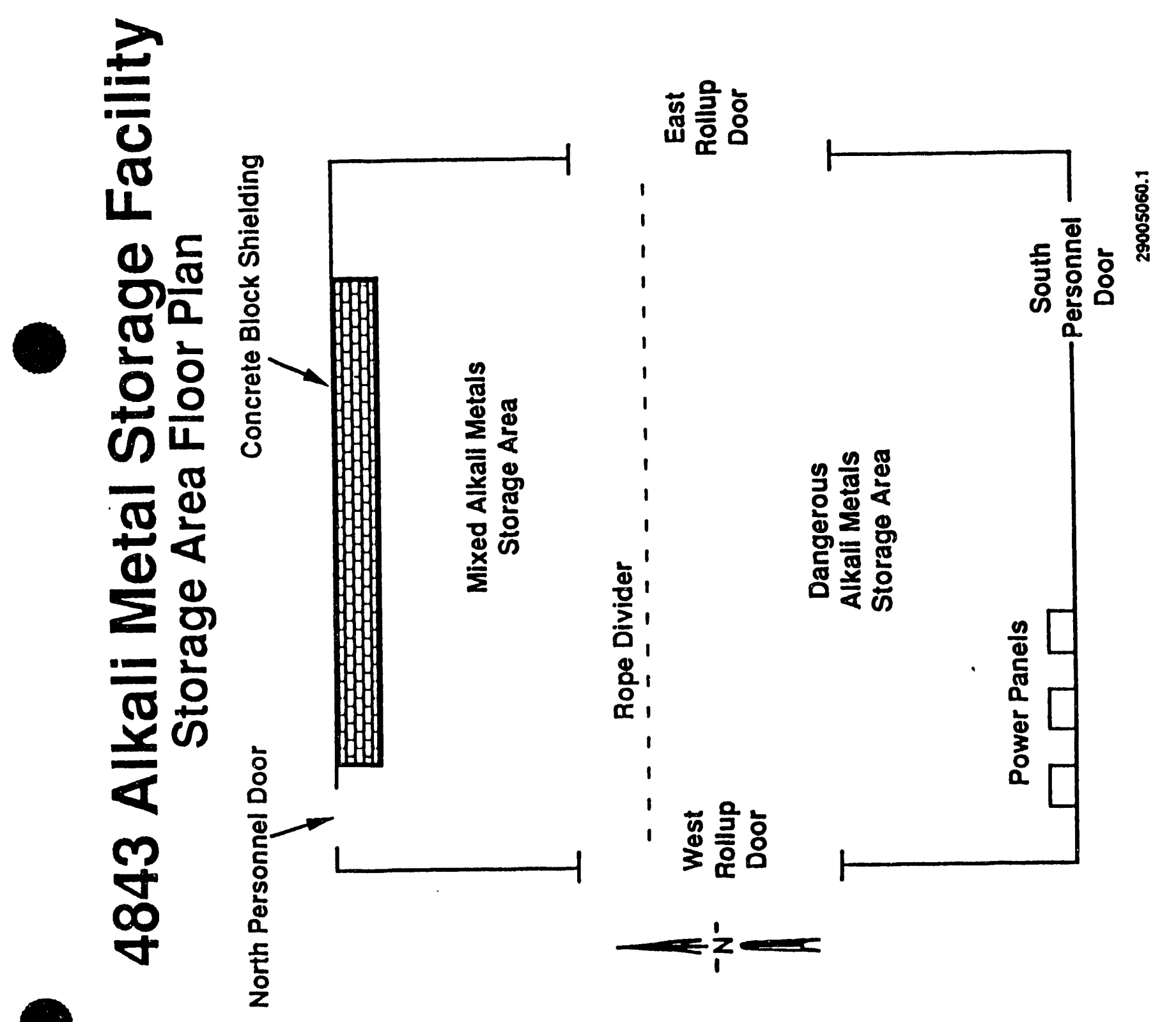


4843 Alkali Metal Storage Facility Rev. 2, 05-31-91, Page 9 of 11

WA7890008967

\section{ALKALI METAL STORAGE FACILITY--400 AREA}

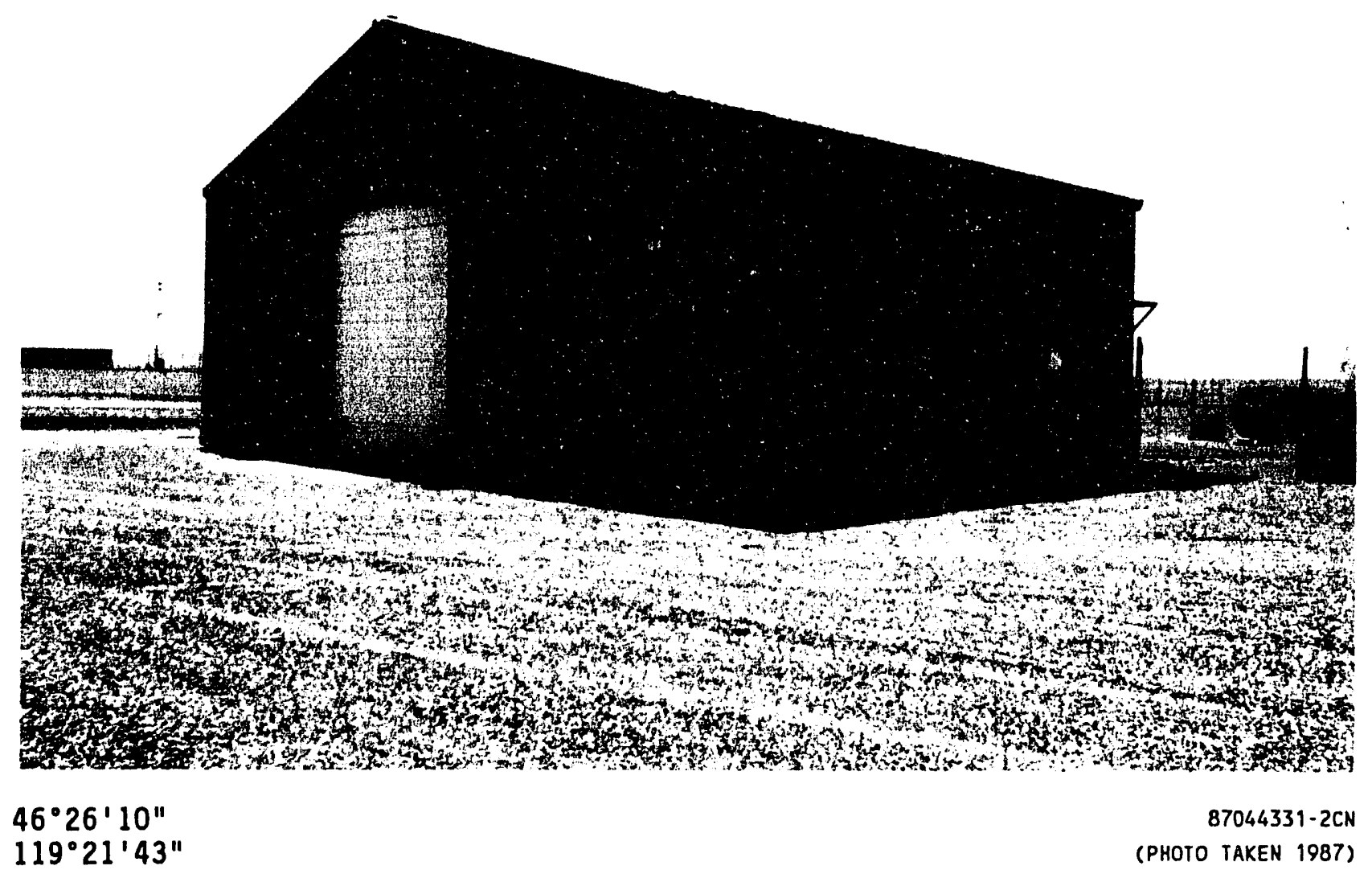




\section{ALKALI METAL STORAGE FACILITY--400 AREA}

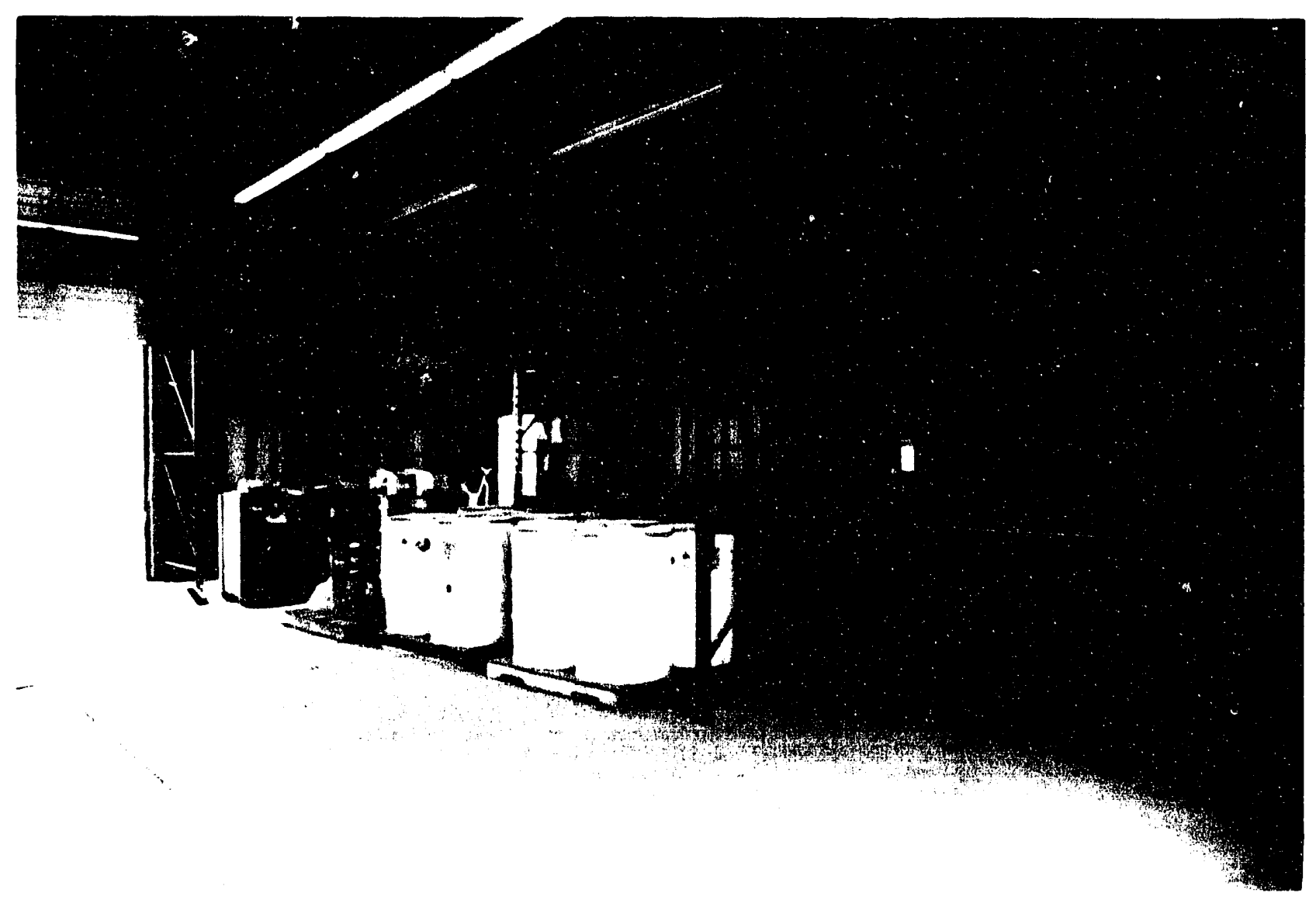

\section{DANGEROUS ALKALI METAL STORAGE AREA}




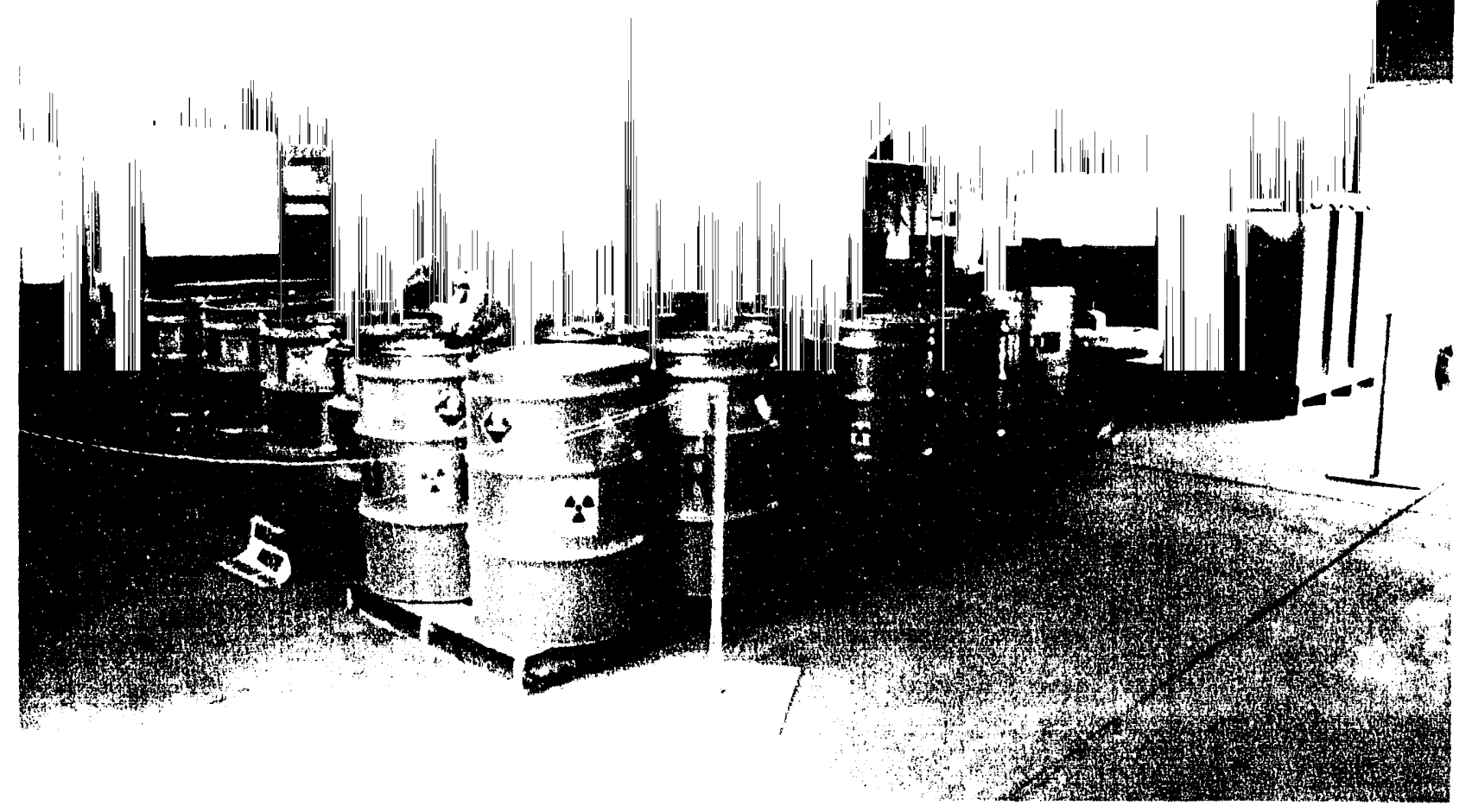

MIXED ALKALI METAL STORAGE AREA

$46^{\circ} 26^{\prime} 10^{\prime \prime}$

90121329-3CN

$119^{\circ} 21^{\prime} 43^{\prime \prime}$

(PHOTO TAKEN 1990) 
DOE/RL-90-49

Revision 0

\section{THE 4843 ALKALI METAL STORAGE FACILITY CLOSURE PLAN}

\subsection{INTRODUCTION}

The Hanford Site, located adjacent to the city of Richland, Washington, is operated by the U.S. Department of Energy-Richland Operations Office (DOE-RL). The 4843 Alkali Metal Storage Facility (4843 AMSF) is a storage unit located on the Hanford Site. The 4843 AMSF began operation as a waste management unit in 1986. The 4843 AMSF has received and presently stores dangerous and mixed alkali metal waste from the Fast Flux Test Facility and from other various operations on the Hanford Site that used alkali metals. The 4843 AMSF is located in the northwest corner of the 400 Area. The 4843 AMSF provides a centralized building to store shipments of dangerous and/or mixed alkali metal waste generated on the Hanford Site.

\subsection{EXECUTIVE SUMMARY}

Clean closure is the proposed method of closure for the 4843 AMSF. Before the first activity of closure, all waste will be removed from the 4843 AMSF. The mixed waste will be transferred to the Hanford Central Waste Complex. The nonradioactive waste will be shipped to an approved treatment, storage, and disposal (TSD) facility.

Closure will be conducted pursuant to the requirements of the Washington State Department of Ecology (Ecology) Dangerous Waste Regulations, Washington Administrative Code (WAC) 173-303-610. This closure plan presents a description of the 4843 AMSF, the history of waste managed, and the procedures that will be followed to close the 4843 AMSF. Following closure, the 4843 AMSF is planned to be used as a storage unit for alkali metal product.

\subsection{THE 4843 ALKALI METAL STORAGE FACILITY CLOSURE PLAN CONTENTS}

The 4843 AMSF closure plan consists of the following nine chapters:

- Introduction (Chapter 1.0)

- Facility Description (Chapter 2.0)

- Process Information (Chapter 3.0)

- Waste Characteristics (Chapter 4.0)

- Groundwater Monitoring (Chapter 5.0)

- Closure Strategy and Performance Standards (Chapter 6.0) 
DOE/RL-90-49

Revision 0

$4 \mathrm{C}$

- Closure Activities (Chapter 7.0)

- Postclosure (Chapter 8.0)

- References (Chapter 9.0). sections.

A brief description of each chapter is provided in the following

\subsubsection{Facility Description (Chapter 2.0)}

This chapter provides a general description of the 4843 AMSF including location and past use. Also included is a general Hanford Site description and permitting history.

\subsubsection{Process Information (Chapter 3.0)}

This chapter provides information on waste storage at the 4843 AMSF. Also included is a general description of the processes responsible for generating the waste, and information on waste management and storage practices at the 4843 AMSF.

\subsubsection{Waste Characteristics (Chapter 4.0)}

This chapter provides information on the physical and chemical characteristics of the waste stored at the 4843 AMSF.

\subsubsection{Groundwater Monitoring (Chaptisr 5.0)}

Groundwater protection regulations established by WAC 173-303-645 only pertain to surface impoundments, waste piles, land treatment units or landfills. Because the 4843 AMSF has been opersted as a container-storage unit, groundwater monitoring is not included as part of the 4843 AMSF closure plan.

\subsubsection{Closure Strategy and Performance Standards (Chapter 6.0)}

This chapter describes the performance standards that will be met and closure activities that will be conducted to achieve clean closure. In general, these standards will be achieved by removing dangerous waste from the 4843 AMSF, and decontaminating or removing all equipment, structure, or other materials containing or contaminated with dangerous waste or waste residue from the waste management unit. 


\subsubsection{Closure Activities (Chapter 7.0)}

Clean closure is the closure strategy proposed for the 4843 AMSF. This chapter describes the sampling activities that will be used to determine the extent of any contamination present. In the event contamination is found, remedial actions also are addressed.

\subsubsection{Postclosure (Chapter 8.0)}

The strategy for the 4843 AMSF is clean closure. However, the actions to be taken, if clean closure cannot be obtained, are described in this chapter. These actions will be in accordance with WAC 173-303-610 (1)(B).

\subsubsection{References (Chapter 9.0)}

References used throughout this closure plan are listed in Chapter 9.0. All references listed here will be made available for review, upon request, to any regulatory agency or public commentator. References can be obtained by contacting the following:

Administrative Records Specialist

Public Access Room H4-22

Westinghouse Hanford Company

P.0. Box 1970

Richland, Washington 99352 . 
DOE/RL-90-49

Revision 0

1
2
3
4
5

This page intentionally left blank. 
DOE/RL $-90-49$

Revision 0

\subsection{FACILITY DESCRIPTION}

\subsection{GENERAL HANFORD SITE DESCRIPTION}

In early 1943, the U.S. Army Cort of Engineers selected the Hanford Site as the location for reactor, chemical separation, and related activities for the production and purification of plutonium. The Hanford Site (Figure 2-1) covers approximately 550 square miles (1,450 square kilometers) of semiarid land, located adjacent to the city of Richland, Washington. The Hanford siie is owned by the j.S. Government and operated by the U.S. Department of ene:"gy (DOE), which operates the Site with the management support of various prime contractors. Since 1987, the Sitewide management and opsiations contractor has been the Westinghouse Hanford Company (Westinghouse Hanford).

Activities at the Hanford Site are centralized in numerically designated areas. The reactors are located along the Columbia River in what are known as the 100 Areas. The reactor fuel processing and waste management units are in the 200 Areas, which are on a plateau located approximately 7 miles (11.27 kilometers) from the Columbia River.

The 500 Area, located adjacent to and north of the city of Richland, contains the reactor fuel manufacturing plants and the research and development laboratories. The 400 Area, located 5 miles ( 8 kilometers) northwest of the 300 Area, contains the Fast Flux Test Facility used for testing liquid metil reactor systems. The 600 Area is the identifier for all locations not specifically given an area designator. Adjacent to and north of Richland, the 1100 Area contains buildings associated with administration, maintenance, transportation, and materials procurement, and distribution. The 3000 Area, located between the 1100 and 300 Areas, contains engineering offices and administrative offices. Administrative buildings also are located in the 700 Area, which is in downtown Richland.

Drawing H-6-958 in Appendix A provides a general overview of the Hanford Site and general 10cation of the 400 Area. Design drawings of the 4843 AMSF are in Appendix; $B$.

\subsubsection{Permitting History}

The Hanford Site is considered to be a single facility. The single dangercus waste permit identification number issued to the Hanford Site by the U.S. Environmental Protection Agency (EPA) and Ecology is EPA/State Identif :ation Number WA7890G08967. This identification number encompasses a number of waste management units within the Hanford Site. All waste management activities carried out under the assigned identification number are considered to be onsite as defined in WAC 173-303. 


\subsection{FACILITY DESCRIPTION AND OPERATIONS}

The 4843 AMSF is located in the northwest corner of the 400 Area (Figure 2-1). There are no other buildings in the immediate vicinity [within 400 feet (122 meters)] of the 4843 AMSF. The gravel area surrounding the building is clear of combustibles for several hundred feet. The building is 40 feet (12 meters) long, 40 feet (12 meters) wide, and 20 feet (6.1 meters) high. The building has an all-steel structural frame, walls, and gable roof, all of which have fiberglass insulation. There are no offices or restrooms inside the 4843 AMSF. The west wall serves as part of the fencing around the laydown area (Figure 2-2). Access to the 4843 AMSF is through two large roll-up doors in the east and west ends and through personnel doors in the southeast and northwest corners (Figure 2-3). Al1 loading and unloading operations are carried out on concrete pads located outside the two rollup doors. No legal boundary exists for the 4843 AMSF. However, the stated boundary is considered to be 10 feet from the building exterior walls.

The 4843 AMSF is used to store dangerous and mixed alkali metal waste, including sodium and lithium, which has been generated at the Fast Flux Test Facility and at various other Hanford Site operations that used alkali metals. Mixed alkali metal waste is stored in the northern half of the 4843 AMSF building in 5-, 30-, and 55-gallon drums, various sealed piping, and sealed components. Adjacent to the northern wail of the 4843 AMSF, a concrete block wall approximately 3 feet $(0.9$ meter) high shields the outside environment from the mixed alkali metal waste. Dangerous alkali metal waste is stored in the southern half of the building. The dangerous and mixed alkali metal waste storage areas are separated by a rope divider (Figure 2-3). The design drawings for the 4843 AMSF are included in Appendix B.

The floor of the 4843 AMSF consists of poured concrete that is essentially an inert material with respect to caustic, oxidizing, combustible, and flammable materials. Presently, there are no visible cracks in the floor. However, there are visible seams consisting of 1-inch (2.54-centimeter) control joints filled with rubber caulking to allow the concrete to expand and contract to help prevent cracking of the slab.

Electric service provides power for the overhead fluorescent lights, exhaust fan, and two hanging heaters within the 4843 AMSF. Because heating the building is not required for alkali metal waste, the heaters presently are not wired for service.

\subsection{SECURITY}

The following sections describe the 24-hour surveillance system and entry control measures used to provide security and to restrict access to the 4843 AMSF. 


\subsubsection{4-Hour Surveillance System}

The entire Hanford Site is a controlled-access area and is expected to remain so during the 4843 AMSF closure. The Hanford Site maintains aroundthe-clock surveillance for the protection of government property; classified information, and special nuclear materials. The Hanford Patrol maintains a continuous presence of armed guards to provide security.

\subsubsection{Barrier and Means to Control Entry}

Manned barricades are maintained around the clock at checkpoints on vehicular access roads leading to the Hanford Site, including the 400 Area. Vehicle operators desiring to enter portions of the Hanford Site beyond these checkpoints must display a DOE issued security identification badge before being admitted. Only DOE vehicles are allowed in the 400 Area. A11 personnel entering or leaving the 400 Area must submit, when requested, to a search of personal items carried into and out of the area.

The 4843 AMSF has warning signs stating "DANGER--UNAUTHORIZED PERSONNEL KEEP OUT" posted at each entrance of the building. These signs are legible from a distance of 25 feet ( 7.6 meters) and are visible from all angles of approach. The doors to the 4843 AMSF are locked when the building is unoccupied. 
DOE/RL-90-49

Revision 0

This page' intentionally left blänk. 
DOE/RL-90-49

Revision 0

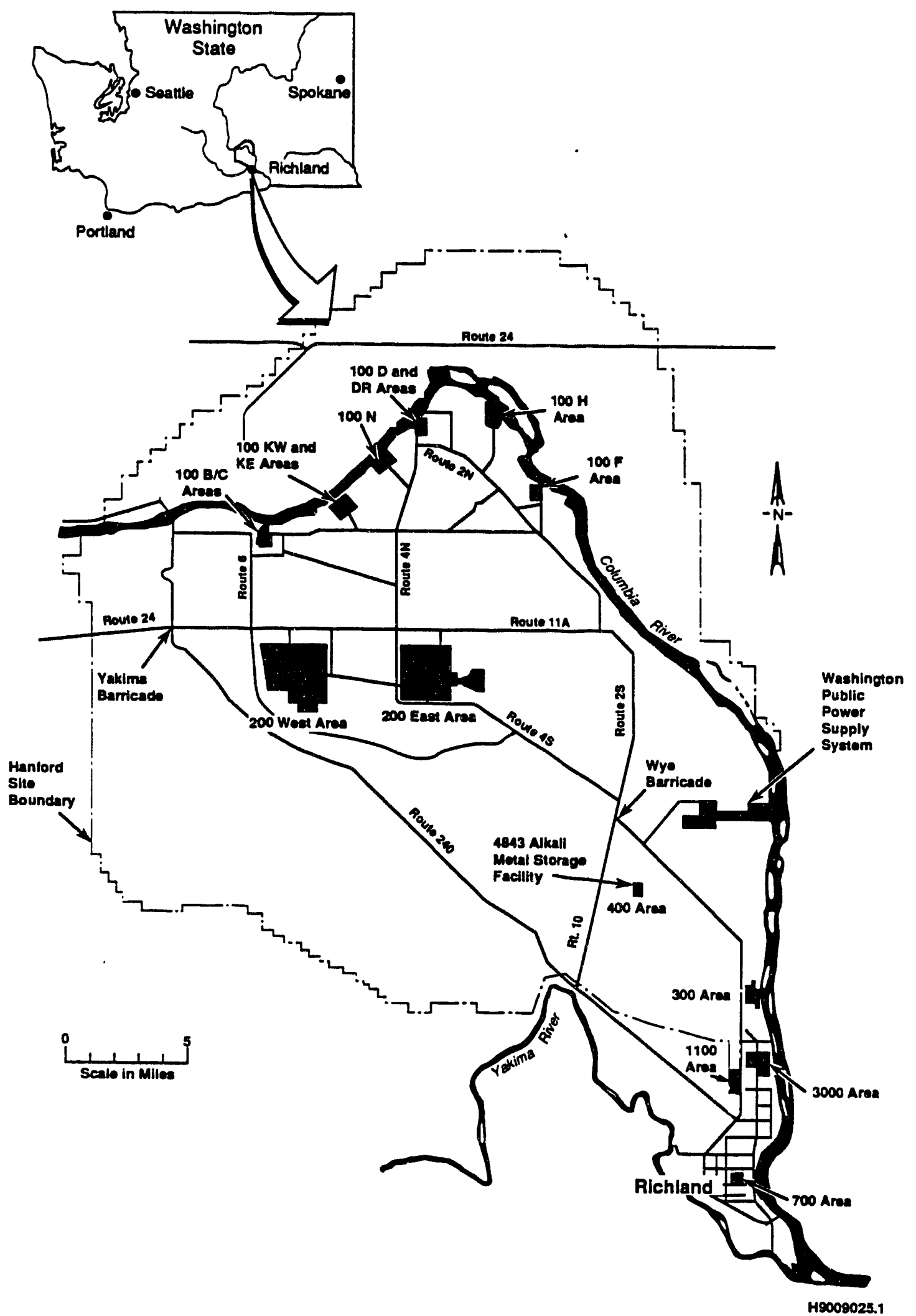

Figure 2-1. Hanford Area Map. 


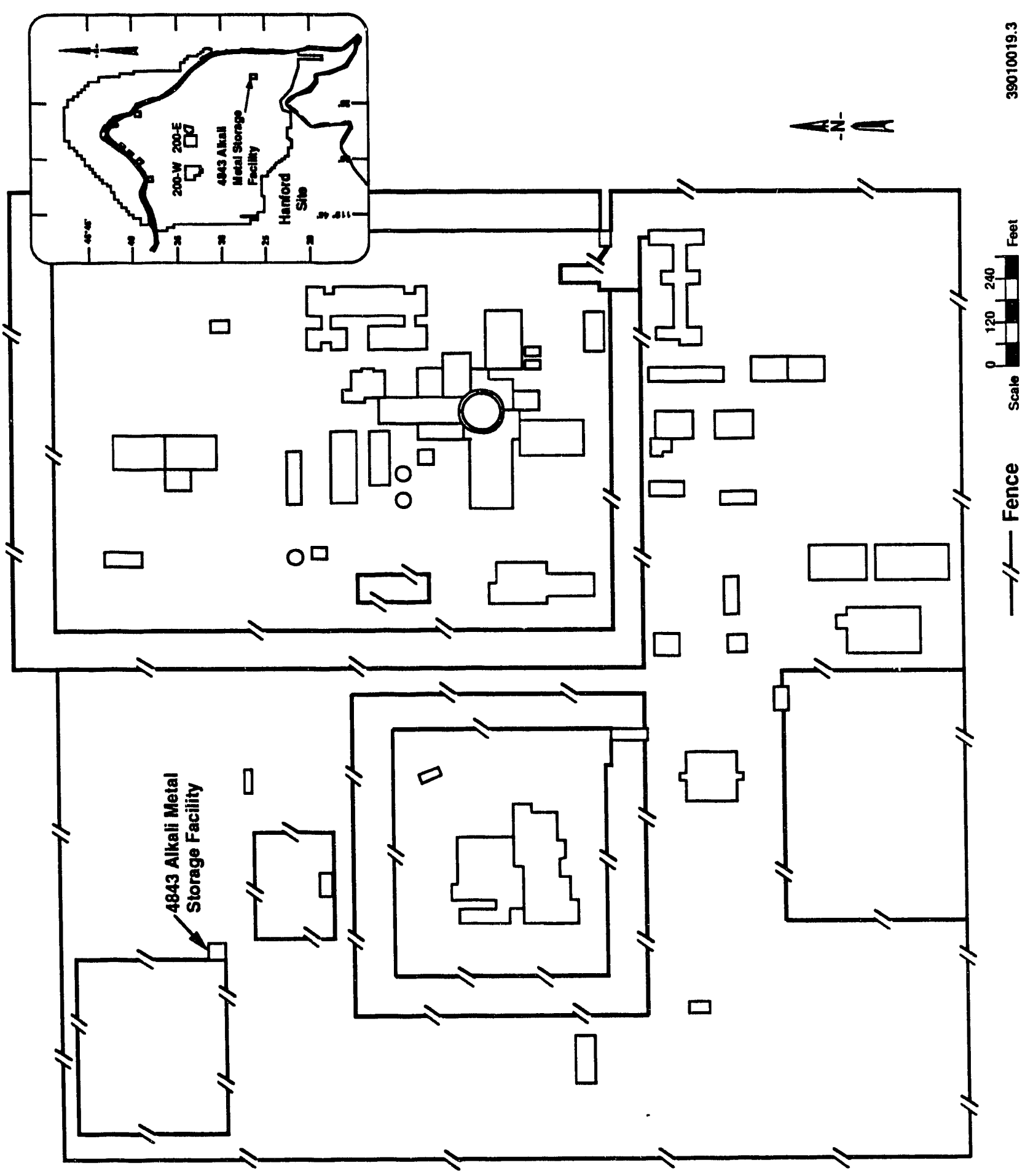

Figure 2-2. The 400 Area Map Showing Location of the 4843 Alkali Metal Storage Facility. 
DOE/RL-90-49

Revision 0

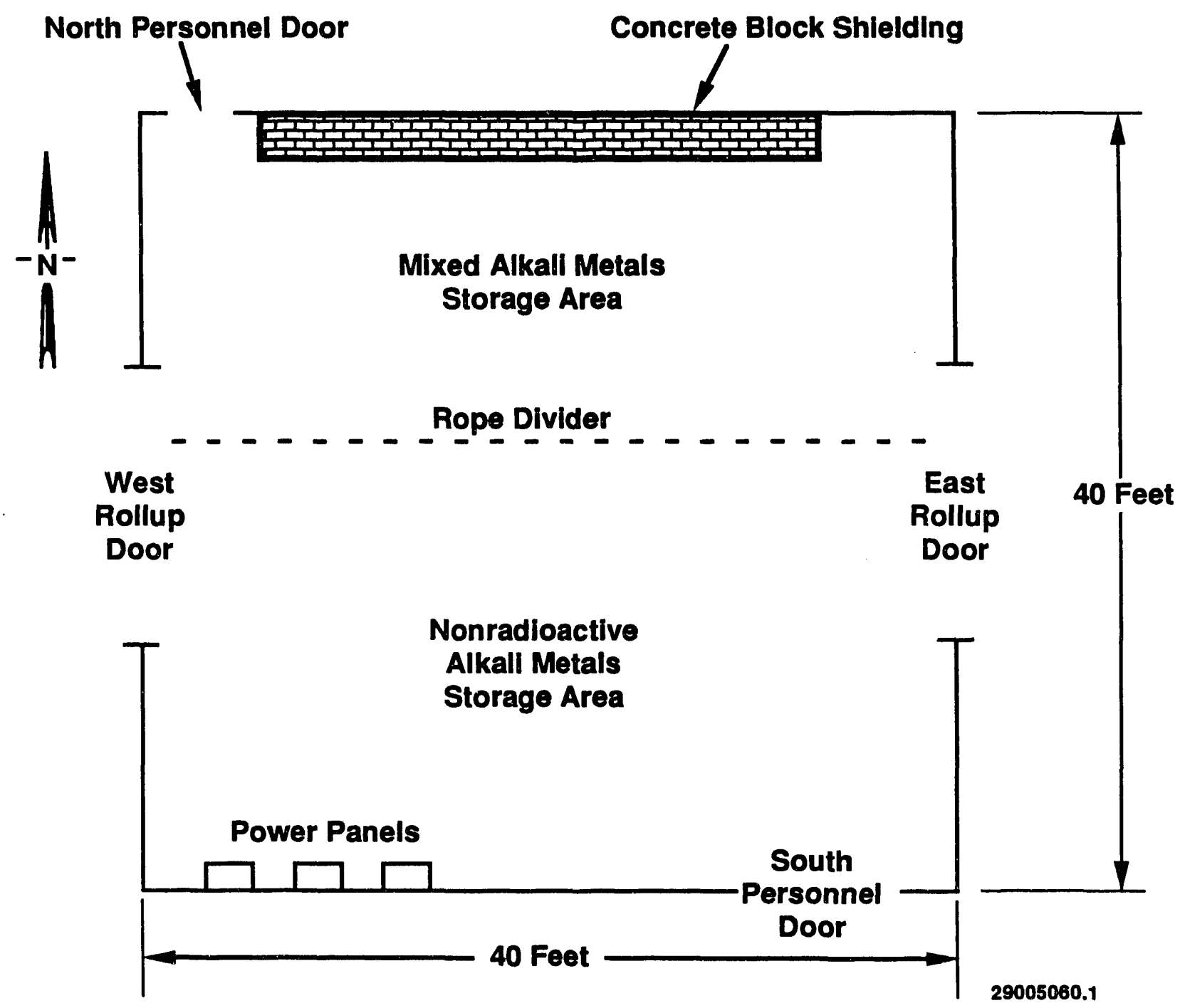

Figure 2-3. Floor Plan of the 4843 Alkali Metal Storage Facility. 
DOE/RL-90-49

Revision 0

\subsection{PROCESS INFORMATION}

The 4843 AMSF has been used primarily to provide a centralized building to receive and store dangerous and mixed alkali metal waste, including sodium and lithium, which has been generated at the Fast Flux Test Facility and at various other Hanford Site operations that used alkali metals. Most of the dangerous and mixed alkali metal waste received consists of retired equipment from liquid sodium processes. The unit continues to store material

(Appendix C). In general, only solid alkali metal waste that is water reactive is stored at the 4843 AMSF.

The 4843 AMSF alkali metal waste can be grouped into the following general types of waste source:

- 'Hot-traps' (hot-traps are cylindrical, stainless-steel mesh screens in piping used to removed impurities from the sodium metal)

- Sealed piping or components (these piping or components are failed equipment with sodium metal residue inside)

- Sodium metal (a result of being captured in a 'catch pan' from leaking piping or components at the Fast Flux Text Facility or from other Hanford Site operations that used alkali metals)

- Alkali metals (resulting from laboratory experimentation).

A sodium-potassium (NaK) mixture also is stored in the 4843 AMSF as a nonwaste material.

\subsection{DESCRIPTION OF CONTAINERS}

The 4843 AMSF only has accepted alkali metal waste properly packaged in U.S. Department of Transportation (DOT) -specified containers or other approved packing (Table 3-1). To keep the reactive alkali metal waste stable, these containers were filled with an inert gas (e.g., argon) and sealed to provide a nonreactive atmosphere. Drums were sealed by a gasketed drum 1 id, locking ring, and locking ring nut. Other containers (e.g., sealed piping or components) were either welded shut or have mechanical sealing equivalent to the drum seal. These containers were chosen in accordance with applicable regulations and were approved for this waste type. Table 3-1 1ists the most common types of containers that have been stored at the 4843 AMSF [and applicable DOT specifications (49 CFR 178)].

Al1 containers stored at the 4843 AMSF are in acceptable condition for dangerous and mixed alkali metal waste. There are no reconditioned containers at the 4843 AMSF. 


\subsection{CONTAINER MANAGEMENT PRACTICES}

The 4843 AMSF contains two different types of storage areas: a dangerous alkali metal waste storage area and a mixed alkali metal storage area (Chapter 2.0, Figure 2-3).

Before being accepted at the 4843 AMSF, each alkali metal waste container is inspected for the following:

- Container condition

- Container seal

- Proper marking and 1 abeling

- Valid radiological release (if applicable).

All alkali metal waste is stored in sealed 5-, 30- or 55-gallon containers, in overpacks, or in some cases, left in the original piping or component and sealed. Solid alkali metal waste is sealed in an inert atmosphere (e.g., argon). No moisture or moisture-bearing material is allowed in the containers.

\subsection{MANAGEMENT OF INCOMPATIBLE WASTE IN CONTAINERS}

The waste coordinator for each generating unit and Solid Waste Engineering are responsible for determining the regulatory status of each waste and for determining its incompatible compounds. Status information is provided to the generator, who packages the waste as instructed.

Transportation Logistics inspect containers for proper packaging, labeling, marking, and manifesting before transporting the containers to the 4843 AMSF. The containers are inspected again at the 4843 AMSF to determine if the waste was properly marked, labeled, and manifested.

Each storage area in the 4843 AMSF contains alkali metal waste. One storage area is for dangerous alkali metal waste and the other storage area is for mixed alkali metal waste. The building consists only of these two storage areas, which are separated by a rope divider (Chapter 2.0, Figure 2-3). 
DOE/RL-90-49

Revision 0

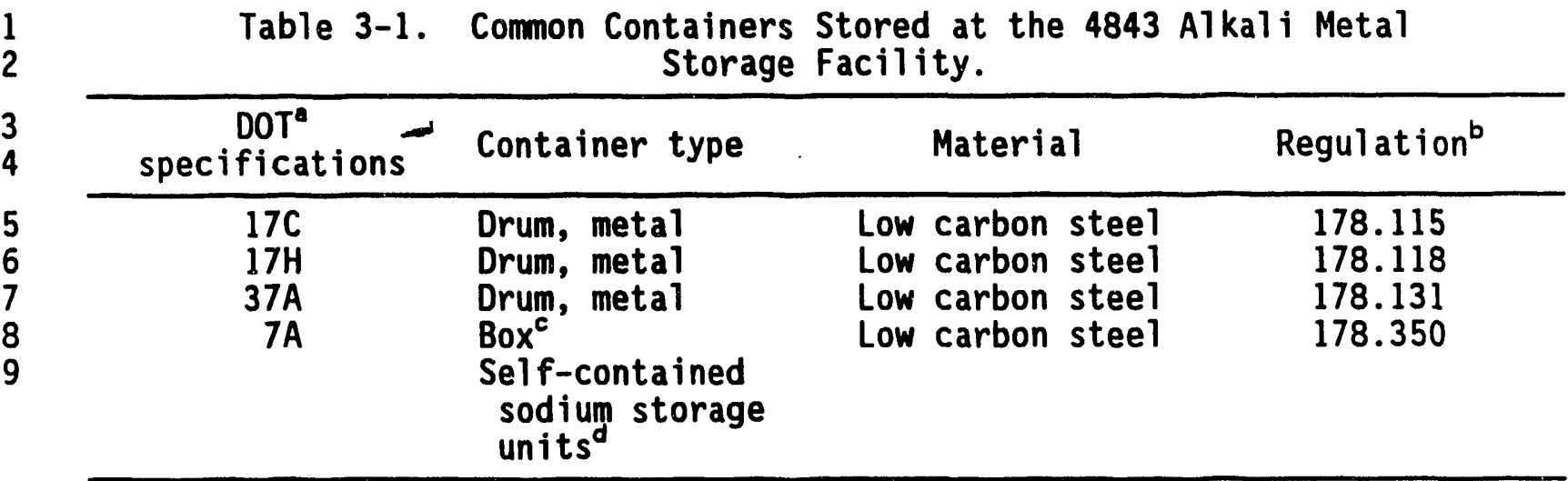

10

11

${ }^{a} U . S$. Department of Transportation.

${ }^{b} 49$ CFR 178.

'General packaging, Type $A$.

12
13

dSodium sealed in original components.

14 
DOE/RL-90-49

Revision 0

\subsection{WASTE CHARACTERISTICS}

This chapter provides information on the physical and chemical characteristics of the waste stored at the 4843 AMSF.

\subsection{ESTIMATE OF MAXIMUM INVENTORY OF WASTE}

The inventory (Appendix C) lists all waste stored in the 4843 AMSF, including waste later shipped offsite to an approved TSD facility. The maximum total waste volume is estimated at 4,000 gallons ( 15,000 iiters), including packing material, based on the inventory including forty-nine 55-gallon drums, three 30-gallon drums, four 5-galion cans, one DOT 7-A container, and sealed piping and equipment components.

Using design conditions, the maximum possible waste quantity allowed is calculated as approximately 22,000 gallons $(83,000$ liters) (Part A Permit).

\subsection{WASTE STORED AT THE 4843 ALKALI METAL STORAGE FACILITY}

The 4843 AMSF has received dangerous and mixed alkali metal waste from Hanford Site generators. Alkali metal waste refers to either sodium or lithium metal waste. Mixed waste is defined as containing both radioactive and hazardous components (DOE 1984). Most of the dangerous and mixed alkali metal waste received at the 4843 AMSF consists of retired equipment from liquid sodium processes. The waste is segregated within the 4843 AMSF depending on whether the alkali metal waste is dangerous or mixed. The alkali metal waste stored at the 4843 AMSF is listed in WAC 173-303-090 as having the characteristics of ignitability (dangerous waste number D001), corrosivity (D002), and reactivity (D003). The alkali metal waste is identified with Ecology waste code designations by using information from product manufacturers, material safety data sheets, laboratory analysis, and such references as the Dangerous Properties of Industrial Materials (Sax 1984), 40 CFR 302.4 (EPA 1985), Registry of Toxic Effects of Chemical Substances (NIOSH 1986), and The Condensed Chemica? nictionary (Sax and Lewis 1987). Waste also is characterized according to the requirements of 40 CFR 261 (EPA 1988).

It is the responsibility of the Hanford Site generators to completely and correctly identify the constituents of their waste. Based on waste identification information provided by the waste coordinator of the generating unit, Solid Waste Engineering designates the waste in accordance with WAC 173-303-070. The 340 Facility and Tanker maintains auditable copies of the following records for waste stored at the 4843 AMSF, as applicable:

- All records providing a description of the waste

- Documentation identifying the dangerous characteristics of the waste

- The basis for waste designation 
DOE/RL-90-49

Revision 0

- Laboratory reports with chemical, biological, and physical analysis of samples

- Manifests

- Land disposal restriction documentation.

In general, each package is similar in that the only waste that has been accepted at the 4843 AMSF is alkali metal waste sealed in a container having an inert atmosphere. The 4843 AMSF has accepted for storage waste with waste codes identified as D001 (Ignitability), D002 (Corrosivity),

D003 (Reactivity), WTO1 (Extremely Hazardous Waste), and WTO2 (Dangerous Waste, if less than 4 pounds).

All alkali metal waste is stored in 5-, 30-, or 55-gallon drums or in sealed piping and sealed components. None of these containers contain free liquids. Instead, the alkali metal waste was placed under an inert atmosphere and sealed. Because of the reactive nature of the material, moisture segregation was a requirement for the waste generating unit that originally packaged the waste.

Sodium and lithium are designated as dangerous waste because of the ir ignitable, reactive, and corrosive characteristics. On reaction with air carbonates are formed. Both sodium carbonate and lithium carbonate are characteristic category $D$ (least toxic) dangerous waste. The $L D_{50}$ (lethal dose) for oral exposure to rats of sodium carbonate is $4,090 \mathrm{ppm}$ (NIOSH 1986); for lithium carbonate the same $L_{50}$ is $525 \mathrm{ppm}$. Compounds with $L_{50}$ 's at concentrations from 500 to $5,000 \mathrm{ppm}$ are category $D$ dangerous waste as established by WAC 173-303-084. 
$\mathrm{DOE} / \mathrm{RL}-90-49$

Revision 0

\subsection{GROUNDWATER MONITORING}

There have been no historical discharges to the groundwater from the 4843 AMSF. Groundwater protection regulations established by WAC 173-303-645 only pertain to surface impoundments, waste piles, land treatment units, or 1andfills. Because the 4843 AMSF has been operated as a container-storage unit, groundwater monitoring is not included as part of the 4843 AMSF closure plan. 
DOE/RL-90-49 Revision 0

This page intentionally left blank. 
DOE/RL-90-49

Revision 0

\subsection{CLOSURE STRATEgY AND PERFORMANCE STANDARDS}

This chapter describes the closure strategy and performance standards that will be met and closure activities that will be conducted to achieve clean closure. In genera?, these standards will be achieved by removing tangerous waste from the 4843 AMSF and decontaminating to levels protective of human health and the environment, or removing all equipment, structures, or other materials containing or contaminated with dangerous waste or waste residue from the waste management unit.

\subsection{GENERAL CLOSURE STRATEGY}

The 4843 AMSF is a clean, well-maintained waste management unit. The 340 Facility and Tanker maintains detailed records of materials stored at the 4843 AMSF (Appendix C). Spills and other unusual occurrences were handled iromptly and are well documented (Appendix D). Closure of the 4843 AMSF will be accomplished by verifying that potentially dangerous constituents stored in the 4843 AMSF are not present above action levels. This will be assessed using information obtained from implementation of sampling activities outlined in Chapter 7.0. No postclosure artivities are anticipated.

The only waste stored in the 4843 AMSF has been alkali metal [sodium and lithium (Section 4.2)]. Most of the dangerous and mixed alkali metal waste received consisted of retired equipment from liquid sodium processes. Alkali metals have the property of being very reactive in an air environment. As a result, any spills or releases of alkali metals are not anticipated to be found in an unreacted state. The compounds anticipated after reaction with the air are carbonates of lithium and sodium.

These carbonates are only dangerous in very large quantities and concentrations (Section 4.2). The concentration expected to be found within the 4843 AMSF is extremely small relative to the size of the building. Closure will be achieved by removing surface deposits of sodium and ithium carbonates from the building and floor. Effort will focus on the interior of the building where the waste was stored. The two reported spills (Appendix D) occurred inside the building.

Three containers of radioactive mixed waste were stored outside the building for three months in 1989. This is the only report of waste being stored outside of the building. The three containers, a 7A container, a Hot Trap and a Fermi Heat Exchanger, are drum numbers 80,81 , and 82 on the waste inventory provided in Appendix $C$. The containers were monitored weekly with no spills or leaks detected. Therefore, there is no reason to suspect any contamination out side the building. 
DOE/RL-90-49

Revision 0

\subsection{GeNERAL CLOSURE PROCEDURE}

The 4843 AMSF will be closed in a manner consistent with Ecology guidelines and regulations (WAC 173-303-610). The general closure procedure is detailed as follows.

After removal of waste inventory, closure activities will entail sampling and decontamination, or removal and disposal of the structure and equipment. These activities will consist of the following steps (as necessary).

1. Perform visual and radiological survey of building interior.

2. Decontaminate associated building equipment to below action levels.

3. Decontaminate building floor and walls, as described in Section 7.4.

4. Perform verification sampling of the building and associated equipment to determine the effectiveness of decontamination procedures.

5. Repeat remediation and verification sampling until removal of all contaminants above action levels is verified or the component is properly disposed of.

6. Decontaminate equipment used in performing closure activities.

7. Designate and dispose of all contaminated materials and rinsates generated during the closure activities.

8. Certify that closure activities were completed in accordance with the approved plan.

Action levels refer to chemical concentrations that prompt an action. The action level of the metal surfaces (wal1s) is the limit of quantitation of the wipe sample method. The action level for verification cleanup of the concrete is based on WAC 173-303-084, "Dangerous Waste Mixtures." Any carbonates that may have penetrated concrete floors will be verified to be classed as undesignated waste according to WAC 173-303-9906, "Toxic Dangerous Waste Mixtures Graph," using the following formula:

Equivalent concentration $(\%)=$ percent category $D$ Waste $/ 10,000$ in accordance with WAC 173-303-084 (5)(b). All surface carbonates, above action levels, will be removed.

\subsection{MINIMIZE THE NEED FOR FURTHER MAINTENANCE}

Closure of the 4843 AMSF by removing or decontaminating equipment and structure to the levels specifiad will eliminate the need for further maintenance specific to the 4843 AMSF. 
$\mathrm{DOE} / \mathrm{RL}-90-49$

Revision 0

\subsection{PROTECTION OF HUMAN HEALTH AND THE ENVIRONMENT}

As discussed previously, the 4843 AMSF will be closed by removing or decontaminating, to identified action levels, all dangerous waste and waste residues to protect human health and the environment.

\subsection{RETURN LAND TO THE APPEARANCE AND USE OF SURROUNDINGS}

Following closure of the 4843 AMSF, the 4843 AMSF location will be restored, as necessary, to al low for the continued use of the building, if possible. 
DOE/RL-90-49

Revision 0

This page intentionally left blank. 
DOE/RL-90-49

Revision 0

\subsection{CLOSURE ACTIVITIES}

\subsection{INTRODUCTION}

Before closure activities begin, all containers will be removed from the 4843 AMSF. Contaminated equipment, floors, and walls will be decontaminated or contaminated sections will be removed. All decontamination rinsate will be contained, designated, and disposed of accordingly. Sampling and testing will be conducted to ensure that no contamination remains on or in the storage area.

\subsection{REMOVAL OF DANGEROUS WASTE INVENTORY}

Before the first activity of closure, all waste will be removed from the 4843 AMSF. The mixed waste will be transferred to the Hanford Central Waste Complex. The nonradioactive waste will be shipped offsite to an approved TSD facility.

\subsection{FACILITY SAMPLING}

Closure activities will entail sampling and decontaminating or removing and disposing of the contaminated sections of the structure and equipment. A sampling flow path for the 4843 AMSF components is shown in Figure 7-1. These activities will consist of the following steps, as necessary, to determine what dangerous chemical waste, if any, has contaminated the building or the associated equipment.

1. Perform visual inspection and radiation survey of the interior of the building.

2. Decontaminate the walls and floor using the options described in Section 7.4 .

3. Sample the areas (walls, floor, and building equipment) of the 4843 AMSF.

4. Repeat remediation and verification sampling until contaminant concentrations are at or below action levels, if practical.

5. Decontaminate or dispose of equipment used in performing closure activities.

6. Designate and dispose of all contaminated materials and rinsates generated during closure activities.

7. Restore the area after closure activities are complete.

8. Certify that closure activities were completed in accordance with the approved plan. 
After removal of all stored waste, closure will be achieved by removing all visual surface deposits of sodium and lithium carbonates. The only waste stored in the 4843 AMSF was alkali metal [sodium and lithium (Chapter 4.0)] . Alkali metals have the property of being very reactive in an air environment. As a result, any spills or releases of alkali metals are not anticipated to be found in an unreacted state. The compounds anticipated after reaction with the air are carbonates of lithium and sodium (Chapter 4.0). These carbonates are only dangerous in very large quantities. The concentration, if any, at the 4843 AMSF is expected to be extremely small relative to the size of the building.

Effort will focus on the interior of the building where the waste has been stored. The two reported spills both occurred inside the building (Appendix D).

After the waste inventory has been removed, the interior of the building will be radiation surveyed. Radiation surveys will be performed according to established Westinghouse Hanford Company procedures [Environmental

Investigation Instructions (EII) 2.3, "Administration of Radiation Surveys to Support Environmental Characterization Work on the Hanford Site," (WHC 1988)] for worker protection and unit characterization. In areas where surveys show measurable radioactivity, the samples and residue collected also will be surveyed for radiation and a visual inspection will be performed. Any waste depcsits found will be removed and disposed of. The floor and walls will then be decontaminated using methods described in Section 7.4.

Any dangerous waste generated during the decontamination of the structure will be containerized, sampled, designated, and shipped to a permitted TSD facility. All materials packaged for shipment will be shipped in DOT-approved containers that are compatible with the waste contents. All containers will be marked, labeled, and shipped with an accompanying manifest in accordance with applicable regulations.

\subsubsection{Decontamination of Building Equipment}

Any contaminated building equipment will be decontaminated with an appropriate decontamination solution or discarded. The decontamination rinsate will be containerized, sampled, designated (in accordance with WAC 173-303-070), and, if regulated, shipped to a permitted TSD facility. materials packaged for shipment to a TSD facility will be in DOT-approved containers that are compatible with waste contents. All containers will be labeled and shipped with an accompanying manifest. All dangerous waste rinsate generated from decontamination of the equipment will be handled in the previousiy stated manner. Equipment will be decontaminated until wipe sample analysis shows no contamination above human health and environmentally based thresholds or disposed of as dangerous or mixed waste. 
DOE/RL-90-49

Revision 0

\subsubsection{Sampling and Verification of the Walls}

The walls of the 4843 AMSF were not used for the storage of waste. Also, spills that could result in airborne contamination are not expected to have occurred within the 4843 AMSF. Thus, the type of waste and the way the waste was handled suggest that there is no basis to suspect the walls or the ceiling will be contaminated.

Verification of the absence of contamination on the walls will be accomplished using a radiation survey and visual inspection. In addition, authoritative wipe samples of the exposed metal surfaces will be taken from stained or rusted areas as determined during visual inspection. The wipe samples will be analyzed for the presence of lithium and sodium carbonates. The only reliable information to be obtained from wipe-sample verification of these metal surfaces is the presence or absence of the material and not the relative quantity with which to determine dangerous waste equivalent concentrations. However, these carbonates are only dangerous in large quantities and concentrations (Chapter 4.0). Any contaminants found are expected to be in concentrations that are extremely small relative to the bulk material. Therefore, after removal of surface deposits the walls will be considered to be clean. If it is not possible to decontaminate the surface until demonstrated to be clean, the contaminated sections will be removed and discarded appropriately. Additional samples will be taken, if necessary, to determine the boundaries of contamination.

Wipe samples will be collected according to standard sampling techniques (EPA 1987) using Whatman" No. 42 filter paper or equivalent. The papers will be laboratory prepared with a dilute $(1: 100)$ nitric acid solution and will be analyzed for sodium and lithium. One filter paper will be used to wipe down the surface area to be analyzed. The filter paper will be held with clean gloves to prevent contamination. A new pair of gloves will be used for each wipe sample. Care will be taken to wipe the surface only once throughout the sampling effort. After the area is wiped, the filter paper will be folded with the exposed side in and folded again to form a $90^{\circ}$ angle in the center of the paper. The filter will be placed into a small glass container, angle first, and sealed.

\subsubsection{Sampling and Verification of Concrete Floor}

The floor of the 4843 AMSF consists of a poured concrete with an area of approximately 1,613 square feet (150 square meters) as shown in Figure 2-3 in Chapter 2.0. Presently there are no visible cracks within the floor. However, there are visible seams where 1-inch (2.54-centimeter) control joints are filled with rubber caulking to allow the concrete to expand and contract to help prevent cracking of the slab. The 4843 AMSF is divided by a rope into two storage areas: the dangerous alkali metal storage area and the mixed alkali metal storage area. To date, two containers that were located within the mixed alkali metal storage area are known to have leaked (Appendix D).

"Whatman is a trademark of Whatman, Inc. 
DOE/RL-90-49

Revision 0

These leaks released a small amount of sodium carbonate and sodium hydroxide on the concrete floor. (Sodium hydroxide reacts with carbon dioxide in the air to form sodium carbonate.) The leaks were cleaned up, according to existing procedures, and the floor was.released for use.

The floor will undergo an initial radiation survey after which it will undergo a high-pressure steam cleaning wash. Decontamination will address minimizing liquid used and how the wash will be conducted. The rinsate will be analyzed according to the protocol outlined in SW-846 (EPA 1986).

Unlike the metal walls, the possibility exists that the carbonates have penetrated and embedded in the concrete floor. Thus, verification is necessary to ensure that any carbonates remaining within the concrete are below the levels listed by the state for dangerous waste mixtures (WAC 173-303-084). Seven samples of the concrete floor will be taken from the locations noted in Figure 7-2. These locations are based on results of random number generator (Table 7-1). Samples may be obtained by chip or coring method. Authoritative concrete samples also will be taken from cracks or stained areas found in the concrete floor as determined at the time of closure.

The concrete samples collected will be analyzed for soluble sodium and lithium carbonates. The action level for verification of cleanup is based on WAC 173-303-084, "Dangerous Waste Mixtures." Any carbonates that might have penetrated the concrete floors will be verified to be classed as undesignated waste according to WAC 173-303-9906, "Toxic Dangerous Waste Mixtures Graph," using the following formula:

$$
\text { equivalent concentration }(\%)=(\text { category } D \text { waste } \%) / 10,000
$$

in accordance with WAC 173-303-084(5)(b).

If the analyses of the concrete samples indicate that contamination is present, the decontamination procedure will be repeated until no contamination is found, or until the decontamination is no longer effective. If it is not possible to decontaminate an area fully, additional samples will be taken to determine the extent of contamination. The contaminated sections of the floor will be removed, placed in a containment module, and disposed of based on the results of the designating sample.

\subsubsection{Decontamination of Equipment Used for Closure}

Extreme care is necessary in field sampling to ensure that there is no cross-contamination of samples by sampling equipment. To prevent this source of contamination, freshly cleaned or disposable sampling tools will be used. If applicable, decontamination wash water will be placed in 55-gallon drums and solidified with a clay mixture for disposal as low-level radioactive or mixed solid waste. Whenever possible, equipment will be cleaned in the laboratory according to procedures specified in EII 5.5 "1706-KE Laboratory Decontamination of RCRA/CERCLA Sampling Equipment" (WHC 1988). 
DOE/RL-90-49

Revision 0 2

3

4

\subsubsection{Sampling Container Decontamination Procedures}

Containers will be purchased precleaned from the factory and maintained under strict chain-of-custody procedure to preserve the integrity of the samples from collection through disposal. After analysis, sample containers will be disposed of properly.

\subsubsection{Quality Assurance and Quality Control Procedures}

All procedures will be performed in accordance with the Quality Assurance Project Plan (Appendix G), Environmental Investigations and Site Characterization Manual (WHC 1988), Quality Assurance Manual (WHC 1989a), Environmental Compliance Manual (WHC 1989b), and pertinent EPA guidance (e.g., SW-846).

7.3.6.1 Field Quality Assurance and Quality Control Procedures. Field quality assurance and quality control (QA/QC) will be ensured through the use of sampling duplicates and blanks described as follows. The QA/QC samples will be collected daily during sampling operations as determined by the cognizant engineer.

Field blanks will consist of pure deionized, distilled water that is transferred to a sample container at the site and preserved with the reagent specified for the analytes of interest. Field blanks will be used to check for possible contamination originating with the reagent or the sampling environment, and will be collected daily when the cleaning rinsate is sampled.

Wipe sample blanks will consist of filter paper that has been laboratory prepared with the appropriate solution and will be placed in a sample container in the field. Blanks will be collected with the wipe samples to determine if contaminants were introduced by the paper, nreparation solution, or sampling environment.

Equipment blanks will be pure deionized, distilled water washed through decontaminated sampling equipment and placed in containers identical to those for actual field samples. Equipment blanks will be used to verify the adequacy of sampling equipment decontamination procedures.

7.3.6.2 Laboratory Quality Assurance and Quality Control Procedures. The analytical laboratories will ensure the integrity and validity of test results through use of an internal quality control program. The program will meet the criteria of SW-846. A system of reviewing and analyzing the results of these samples will be maintained to detect problems caused by contamination, inadequate calibrations, miscalculations, improper procedures, or other factors. Standard methods will be used and alternate methods that are developed or adapted will be tested and completely documented. A11 methods and method changes will be approved by the operations contractor. 
The QA/QC procedures specific to individual methods will be detailed in the analytical procedures documented by the laboratory and will be included with each batch of samples analyzed.

7.3.6.3 Field Logbook. The personnel conducting sampling will maintain an official logbook during the sampling activities. The logbook will be maintained as described in EII 1.5 "Field Logbooks" (WHC 1988).

7.3.6.4 Modifications to Waste Sampling and Analysis Plan. The optimal aspects of sample design are sometimes not achievable because of unanticipated or changing conditions. Factors adversely influencing sampling efforts can include equipment malfunction or breakdown, improper equipment, physical barriers to coring equipment, and overly optimistic evaluation of other physical conditions at the site. When modifications to the planned activity are necessary, the modifications will be recorded in the field logbook along with circumstances requiring the actions. The field logbook will be reviewed and signed by the project manager daily. This procedure will provide an accurate record of modifications and Westinghouse Hanford approval, while (1) allowing sampling to proceed safely, and (2) maintaining efficient manpower and equipment usage. When modifications to an EII are required, procedures outlined in EII 1.4 "Deviations from Environmental Investigation Instructions" (WHC 1988) will be followed.

\subsubsection{Reporting}

After completion of the sampling effort, verification documents will provide for actual sample locations, number of samples, and specific methods used for collections. Data received from the laboratory will be reviewed, analyzed, and statistically summarized. The results will be used to provide further closure evaluations.

\subsubsection{Evaluation of Data}

After receiving the analytical results, the data will be judged for reliability, reviewed and summarized to eliminate constituents with results below detection limits to make the data more manageable, and statistically evaluated according to procedure in EII 1.11, "Technical Data Management" (WHC 1988). The data will be evaluated for QA/QC, reliability, and significance of contamination levels in comparison with action levels. The following is an outline of how sampling data will be evaluated.

- Evaluate the quality control of the sampling, handling, and analyses to assess the reliability of the data.

- Prepare summary statistics for constituents. 
DOE/RL-90-49

Revision 0

All data collected will be analyzed and will include the following:

- Number of 'less than' detection limit values

- Total number of values

- Mean

- Standard deviation

- Coefficient of variation

- Limit of quantitation

- Representative method precision

- Minimum value

- Maximum value.

Data reliability will be assessed by evaluating the sample handing and analysis quality control according to procedures. Sample-handling quality control will be evaluated by reviewing field documentation and results of quality assurance samples to establish that sampling error was minimized. The review will be conducted to verify that decontaminated equipment was used, that cross-contamination was minimized, that samples were preserved properly, and that the chain of custody of the samples was not broken.

\subsubsection{Sampling Equipment, Container, and Preservation}

Sampling equipment used will be appropriate to the spectrum of media that might be encountered. Surfaces to be sampled include metal and concrete (walls and floor) and fiberglass insulation.

All samples will be packaged according to EII 5.11 "Sample Packaging and Shipping" (WHC 1988). Samples will be transported to the analytical laboratory within 24 hours of collection. All deviations from SW-846 protocols, including sample size, will be documented with a justification for the deviation.

\subsubsection{Site Safety}

Site safety during all closure activities will involve planning, training, and approved standard procedures.

7.3.10.1 Health and Safety Plan. A health and safety plan (HASP) is required for all dangerous waste sampling sites. The HASP is intended to specify information pertinent to field assignments and to be a guide in unusual situations or emergencies. A site-specific version of the generai RCRA/Comprehensive Environmental ?esponse, Compensation, and Liability Act 
of 1980 (CERCLA) investigation health and safety manual will be developed and used for sampling at the 4843 AMSF. This plan will be developed and completed before initiation of sampling activities in accordance with EII 2.1 "Preparation of Hazardous Waste Operations Permits" (WHC 1988).

\subsubsection{Personnel Training. All personnel involved with the closure} activities at the 4843 AMSF will receive a minimum level of dangerous waste training. Personnel are generally placed into the following job categories.

- Managers and supervisors are responsible for supervising, coordinating, and directing the closure activities and personnel.

- Nuclear Process Operators and Decommissioning and Decontamination workers are responsible for sampling, packaging, and handling of both dangerous and mixed waste.

- Health Physics Technicians are responsible for surveying for radiological and dangerous waste contaminants.

- Crafts personnel are responsible for specialized work. The various crafts include carpenters, electricians, ironworkers/riggers, heavy equipment operators, crane operators, millwrights, pipefitters, and painters.

In addition to the personnel mentioned, any person entering a TSD unit during closure must have the 40 hour hazardous workers training.

Table 7-2 contains a matrix that relates job categories to the individual training course. Appendix $F$ contains brief descriptions of the training courses, including descriptions of the target audience, instructional technique, evaluation method, length of course, and frequency of retraining.

7.3.10.3 Standard Safety Procedures. The following safety procedures will apply each time personnel make a site entry for sampling purposes.

- No personnel will be at the site without a designated 'buddy.'

- Of the personnel entering the site, one will be designated to be in charge.

- Personal protective equipment will be worn as specified. Approved deviations will be entered in the field logbook and signed by the field team leader (cognizant engineer) and the site safety officer.

- Field work will be planned before the site is entered.

- Equipment needed for work will be inventoried and inspected before the site visit to ensure that all equipment is present and in operable condition. 
DOE/RL-90-49

Revision 0

\subsection{DECONTAMINATION AND DISPOSAL OF BUILDING AND CONCRETE PAD}

The interior of the building will be decontaminated using one of the following: damp wipe down, high-pressure steam and suction, vacuum assisted mechanical removal, and sandblasting techniques. It is anticipated that a majority of the decontamination work can be accomplished using damp wipe downs and high-pressure steam and suction. However, the actual method of decontamination will be specified in a decommissioning work plan and will address each area of concern. Decontaminated waste will be designated and the appropriate method of disposal determined.

A 'decommissioning work $p l a n^{\prime}$ is a generic term for the implementation procedure used to provide specific field direction to workers actually performing the decontamination and demolition. The actual decommissioning work plan will specify, in sufficient detail for field implementation, the items addressed in this section. This will be developed and issued just before the work begins.

Sampling will be conducted following the cleaning process to determine the effectiveness of the cleaning procedure and the appropriate remedial options. The analytical results will be evaluated to determine if the building can be used as a storage unit for alkali metal product. If portions of the building do not meet the action levels presented in this closure plan, these portions will be removed and disposed of.

\subsection{SCHEDULE FOR CLOSURE}

A schedule of the closure activities is presented in Figure 7-3. The activities representing the greatest portion of time will be sampling and decontaminating the floor. However, it is unknown how many iterations of decontamination will be required.

\subsection{AMENDMENT OF PLAN}

The closure plan for the 4843 AMSF will be amended whenever changes in operating plans or unit design affect the closure plan, whenever there is a change in the expected time of closure, or if, when conducting closure activities, unexpected events require a modification of the closure plan. The closure plan will be modified in accordance with WAC 173-303-610(3). This plan can be amended any time before certification of final closure of the 4843 AMSF.

If an amendment to the approved closure $\mathrm{plan}$ is required, DOE-RL will submit a written request to Ecology to authorize a change to the approved plan. The written request will include a copy of the closure plan amendment for approval. 


\subsection{CERTIFICATION OF CLOSURE}

Within 60 days of final closure of the 4843 AMSF, the DOE-RL will submit to Ecology a certification of closure. The certification will be signed by both the DOE-RL and an independent professional engineer registered in the state of Washington, stating the unit has been closed in accordance with the approved closure plan. The certification will be submitted by registered mail. Documentation supporting the independent professional engineer's certification will be retained and furnished to Ecology upon request.

The DOE-RL and the independent professional engineer registered in the state of Washington will certify with a document similar to Figure 7-4. 
DOE/RL-90-49

Revision 0

Figure 7-1. Sampling Flow Path. (foldout) 


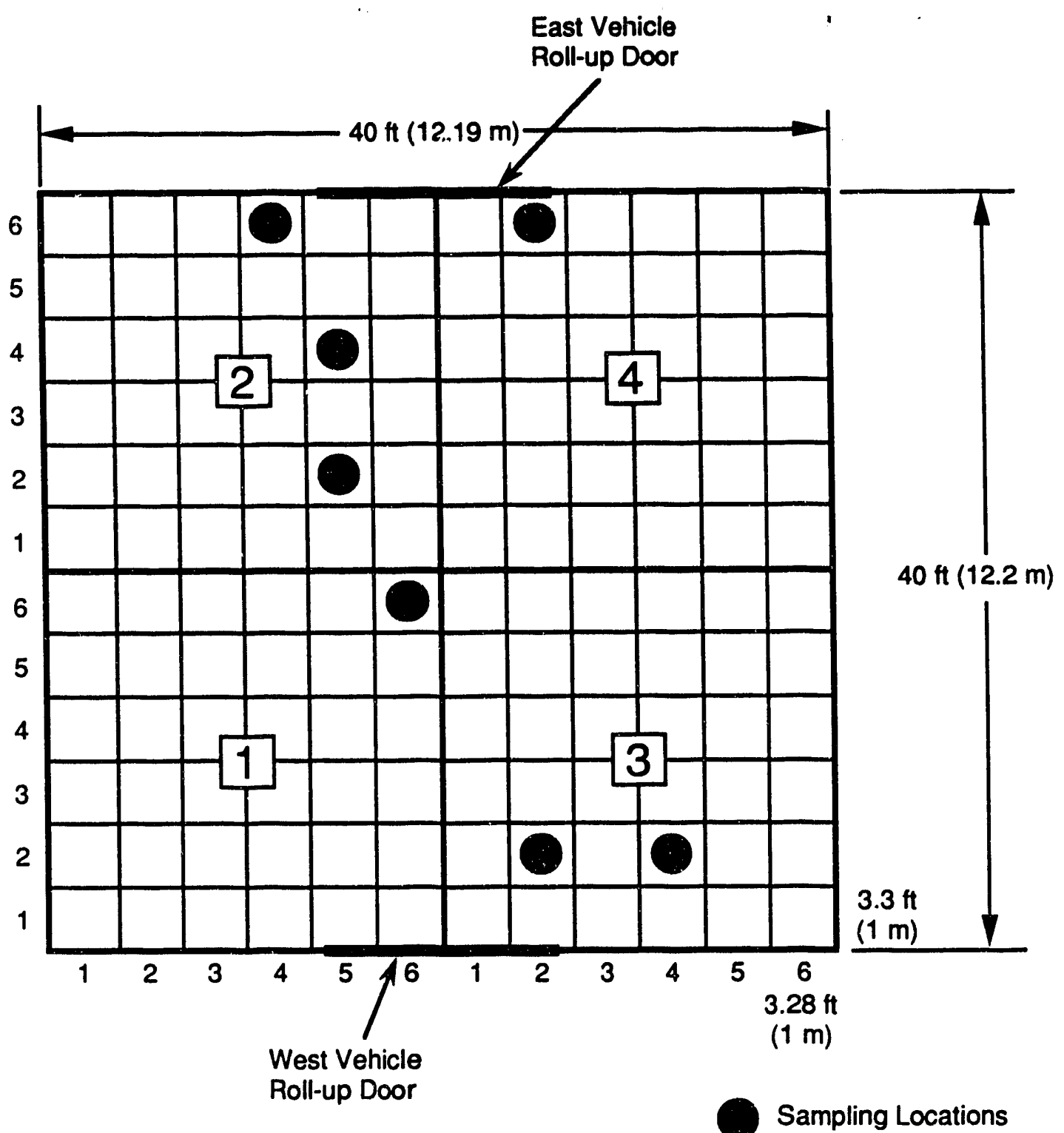

H9009019.3

Figure 7-2. Floor Sampling Locations. 
DOE/RL-90-49

Revision 0

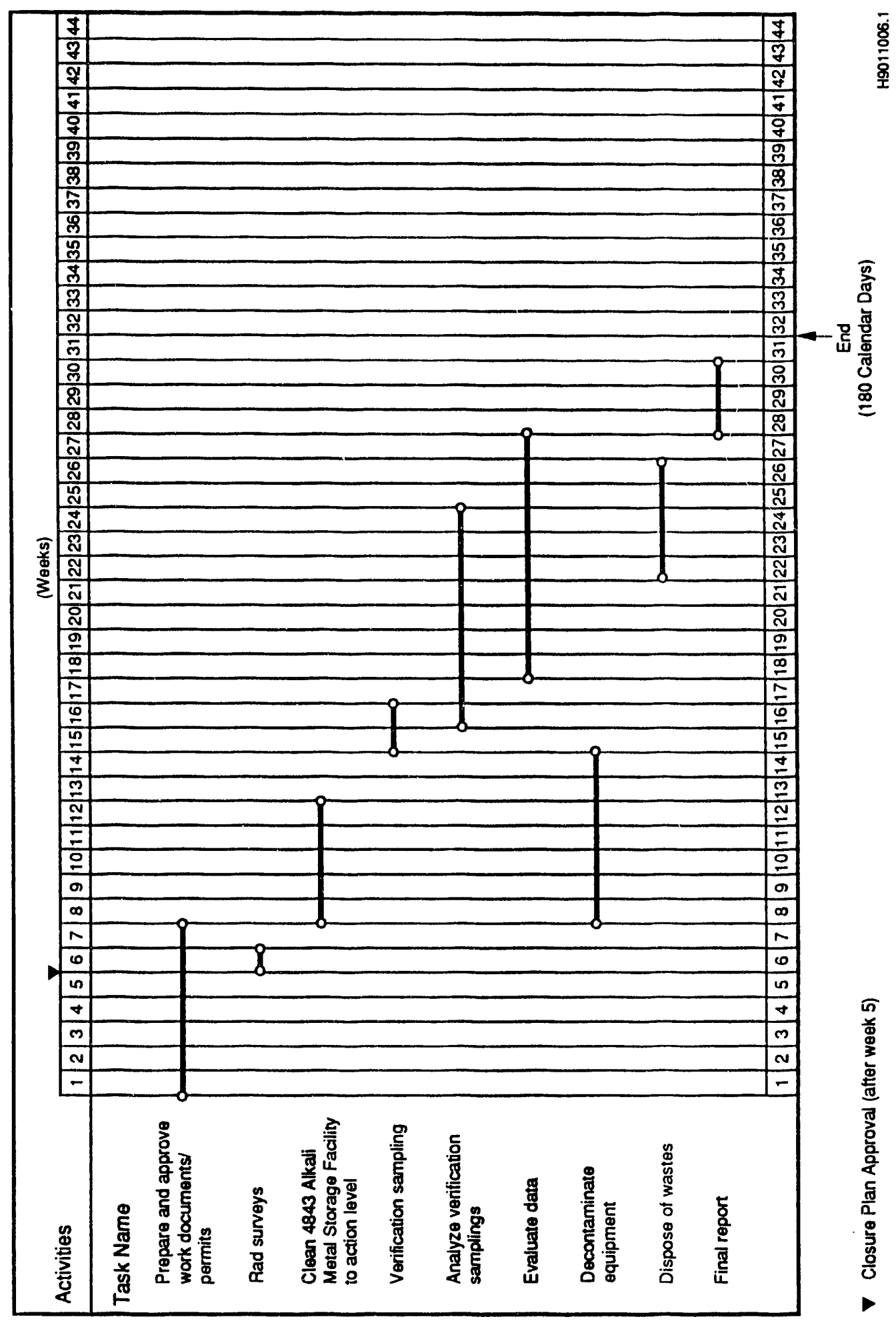

Figure 7-3. Schedule of Closure Activities. 
DOE/RL-90-49

Revision 0

2 4 5

6

7

9

10

11

12

13

14

15

16

17

18

19

20

21

22

23

24

25

26

27

28

29

30

31

32

33

34

\section{CLOSURE CERTIFICATION FOR}

Department of Energy-Richland Operations

Owner/Operator Signature DOE-RL Representative

Date (Typed Name)

\section{P.E.\#}

Signature Independent Registered Professional Engineer Date (Typed name and Washington State Professional Engineer Ticense number).

Figure 7-4. Closure Certification for the 4843 AMSF. 
Table 7-1. The 4843 Alkali Metal Storage Facility Sampling Locations.

\begin{tabular}{|l|c|c|}
\hline \multicolumn{3}{|c|}{ Concrete Floor Sampling Points (Figure.7-2) } \\
\hline & X-Coordinate & Y-Coordinate \\
\cline { 2 - 3 } & Individual Quadrants (6 X 6 Grid) \\
\hline First quadrant & 6 & 6 \\
\hline Second quadrant & 5 & 4 \\
\hline Third quadrant & 4 & 2 \\
\hline Fourth quadrant & 2 & 6 \\
\hline \multicolumn{2}{|c|}{ Three Additional Sampling Locations } & $(12 \times 12$ Grid) \\
\hline First sampling point & 5 & 8 \\
\hline Second sampling point & 8 & 2 \\
\hline Third sampling point & 4 & 12 \\
\hline \multicolumn{2}{|c|}{ NoTE: The floor area is divided into a 12 by 12 grid } \\
\hline
\end{tabular}
with 1 meter spacings. Seven samples, locations determined by random number generator*, will be taken from the floor. To ensure coverage, the floor was divided into four quadrants. One sample will be taken from each quadrant. Three additional samples will be taken from the entire floor area.

* Lotus 1-2-3, is a trademark of Lotus Development Corporation. 
Table 7-2. Company-General Training Matrix.

\begin{tabular}{|l|c|c|c|c|c|}
\hline \multicolumn{1}{|c|}{ Course title } & \multicolumn{4}{|c|}{ Target/audience } \\
\cline { 2 - 6 } & Type & MS & NPO & HPT & CR \\
\hline Generator Hazards Safety Training & $I$ & $X$ & $X$ & $X$ & $X$ \\
Hazardous Waste Worker Safety Training & $I$ & $X$ & $X$ & $X$ & $X$ \\
Hazardous Waste Worker Safety Training, & $C$ & $X$ & $X$ & $X$ & $X$ \\
Refresher & & & & & \\
Hazardous Materials/Waste Job Specific & $I$ & $X$ & $X$ & $X$ & $X$ \\
Training & & & & & \\
*Scott SKA-PAK MSA PAPR & $C$ & $X$ & $X$ & $X$ & $X$ \\
Self-Contained Breathing Apparatus (SCBA) & $C$ & $X$ & $X$ & $X$ & $X$ \\
Training (optional) & & & & & \\
Radiation Safety Training & $C$ & $X$ & $X$ & $X$ & $X$ \\
On-the-Job Training & $C$ & $X$ & $X$ & $X$ & $X$ \\
Cardiopulmonary Resuscitation & $C$ & $X$ & $X$ & $X$ & $X$ \\
Noise Control (optional) & $C$ & $X$ & $X$ & $X$ & $X$ \\
\hline
\end{tabular}

*SKA-PAK is a trademark of Figgie International,

Incorporated.

$\mathrm{C}=$ continuing course.

$I$ = introductory course.

NPO = nuclear process operators and decontamination and decommissioning workers.

MS = manager and supervisors.

$X=$ required course.

$H P T=$ health physics technicians .

$C R=$ crafts. 
DOE/RL-90-49

Revision 0

\subsection{POSTCLOSURE}

This closure plan is proposing clean closure of the 44843 AMSF. However, if clean closure cannot be obtained, the following action will be taken in accordance with WAC 173-303-610 (1) (b).

\subsection{NOTICE IN DEED BOOK}

Within 60 days of the certification of closure, the DOE-RL will sign, notarize, and file for recording the notice indicated below. The notice will be sent to the Auditor of Benton county, P.0. Box 470, Prosser, Washington, with instructions to record this notice in the deed book.

\section{TO WHOM IT MAY CONCERN}

The United States Department of Energy-Richland Operations Office, an operations office of the United States Department of Energy, which is a department of the United States Government, the undersigned, whose local address is the Federal Building, 825 Jadwin Avenue, Richland, Washington, hereby gives the following notice as required by 40 CFR 265.120 and WAC 173-303-610(10) (whichever is applicable):

(a) The United States of America is, and since April 1943, has been in the possession in fee simple of the following describe 1ands: (legal description of the 4843 Alkali Metal Storage Facility).

(b) The United States Department of Energy-Richland Operations Office, by operation of the 4843 Alkali Metal Storage Facility, has disposed of hazardous and/or dangerous waste under the terms of regulations promulgated by the United States Environmental Protection Agency and Washington State Department of Ecology (whichever is applicable) at the above described 1 and.

(c) The future use of the above described 1 and is restricted under terms of 40 CFR 264.117(c) and WAC 173-303-610(7)(d) (whichever is applicable).

(d) Any and a 11 future purchasers of this 1 and should inform themselves of the requirements of the regulations and ascertain the amount and nature of wastes disposed on the above described property.

(e) The United States Department of Energy-Richland Operations Office has filed a suryey plat with the Benton County Planning Department and with the United States Environmental Protection Agency, Region 10, and the Washington State Department of Ecology (whichever are 
DOE/RL-90-49

Revision 0

5 applicable) showing the location and dimensions of the 4843 Alkali Metal Storage Facility and a record of the type, location, and quantity of waste treated.

\subsection{POSTClosure CARE}

Postclosure care is generally required when a waste management unit cannot attain a clean closure.

If it is determined that the 4843 AMSF cannot be remediated under these programs, a postclosure plan will be prepared for the 4843 AMSF at that time. The post closure plan will include the following:

- Inspection plan

- Monitoring plan

- Maintenance plan

- Personnel training

- Postclosure contact

- Provisions to amend the postclosure plan

- Provisions to certify the postclosure plan. 
DOE/RL-90-49

Revision 0

\subsection{REFERENCES}

Comprehensive Environmental Response, Compensation, and Liability Act of 1980 , as amended, 42 USC 9601 et seq.

DOE, 1984, Radioactive Waste Management-Guidance Document, DOE Order 5820.2A, U.S. Department of Energy, Washington, D.C.

DOE-RL, 1989, Draft Remedial Investigation/Feasibility Study Work Plan for the 300-FF-5 Operable Unit, Hanford Site, Richland, Washington, DOE/RL 89-14, U.S. Department of Energy-Richland Operations Office, Richland, Washington.

DCT, 1988, Shipping Container Specification, Title 49, Code of Federal Regulations, Part 178, U.S. Department of Transportation, Washington, D.C.

Ecology, 1989, Dangerous Waste Regulations, Washington Administrative Code, Chapter 173-303, Washington State Department of Ecology, Olympia, Washington.

Ecology, EPA, and DOE, 1990, Hanford Federal Facility Agreement and Consent Order, Vol. 1 and 2, Washington State Department of Ecology, U.S. Environmental Protection Agency, and U.S. Department of Energy, 01 ympia, Washington.

EPA, 1990, Designation, Reportable Quantities, and Notification, Title 40, Code of Federal Regulations, Part 302, as amended, U.S. Environmental Protection Agency, Washington, D.C.

EPA, 1986, Test Methods for Evaluating Solid Waste, Volume 1A, SW-846, U.S. Environmental Protection Agency, Washington, D.C.

EPA, 1990, Identification and Listing of Hazardous Waste, Title 40, Code of Federal Regulations, Part 261, U.S. Environmental Protection Agency, Washington, D.C.

NIOSH, 1986, Registry of Toxic Effects of Chemical Substances, 1985-86 ed., National Institute for Occupational Safety and Health, U.S. Department of Health and Human Services, Washington, D.C.

Resource Conservation and Recovery Act of 1976, as amended, 42 USC 6901 et seq.

Sax, N. Irving, 1984, Dangerous Properties of Industrial Materials, Van Nostrand Reinhold Company, New York, New York.

Sax, N. Irving and Richard J. Lewis, Sr., 1987, Hawley's Condensed Chemical Dictionary, Van Nostrand Reinhold Company, New York, New York. 
1 WHC, 1988, Environmental Investigations and Site Characterizations Manual, 2 WHC-CM-7-7, Westinghouse Hanford Company, Richland, Washington.

4 WHC, 1989a, Quality Assurance, WHC-CM-4-2, Westinghouse Hanford Company, 5 Richland, Washington.

7

8

WHC, 1989b, Environmental Compliance Manual, WHC-CM-7-5, Westinghouse Hanford Company, Richland, Washington. 
DOE/RL-90-49

Revision 0

APPENDIX A

HANFORD SITE MAP 
DOE/RL-90-49

Revision 0

1
2
3
4
5

. This page intentionally left blank. 
<smiles>CC(C)CC1CCCC1</smiles> 


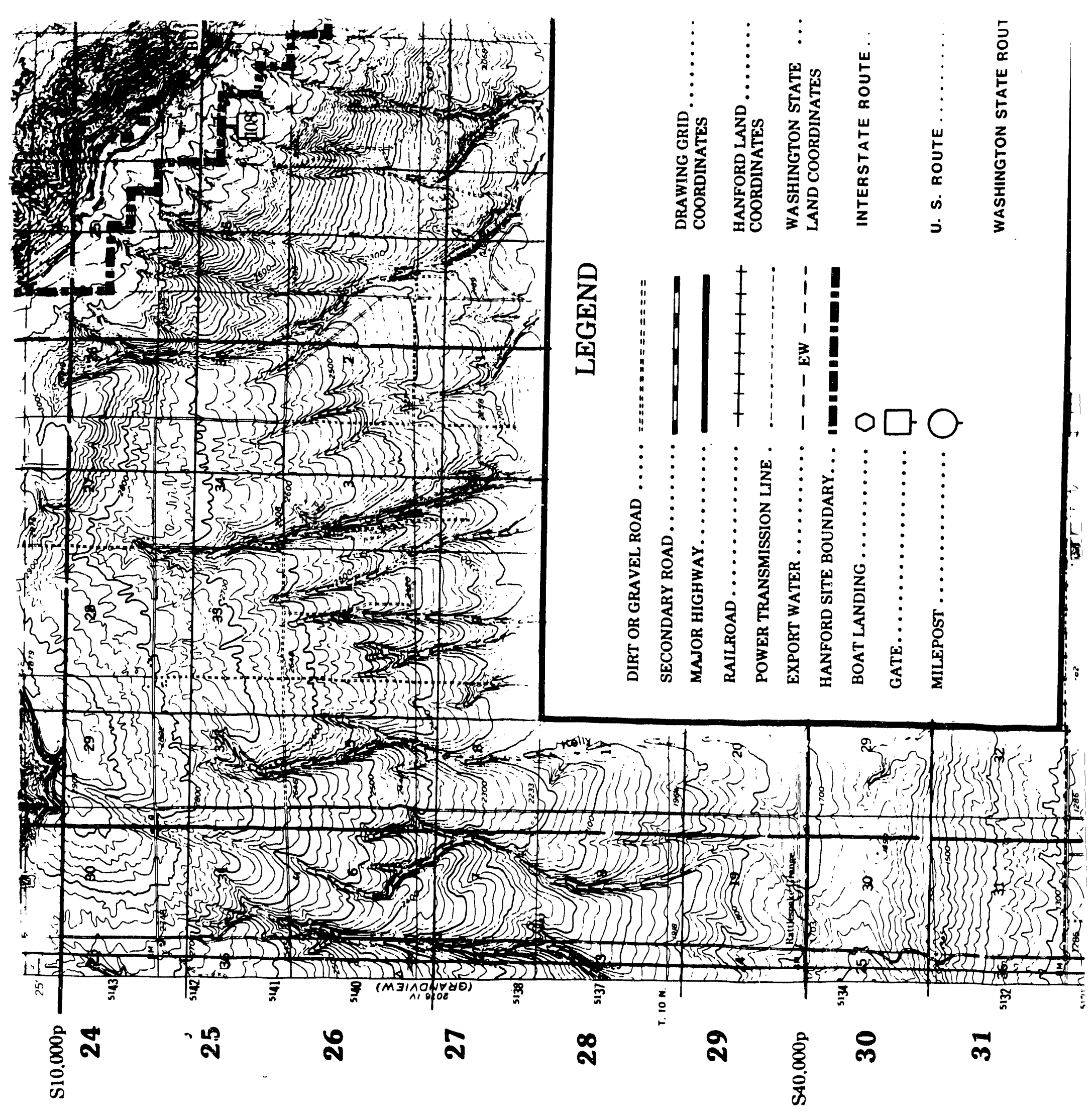




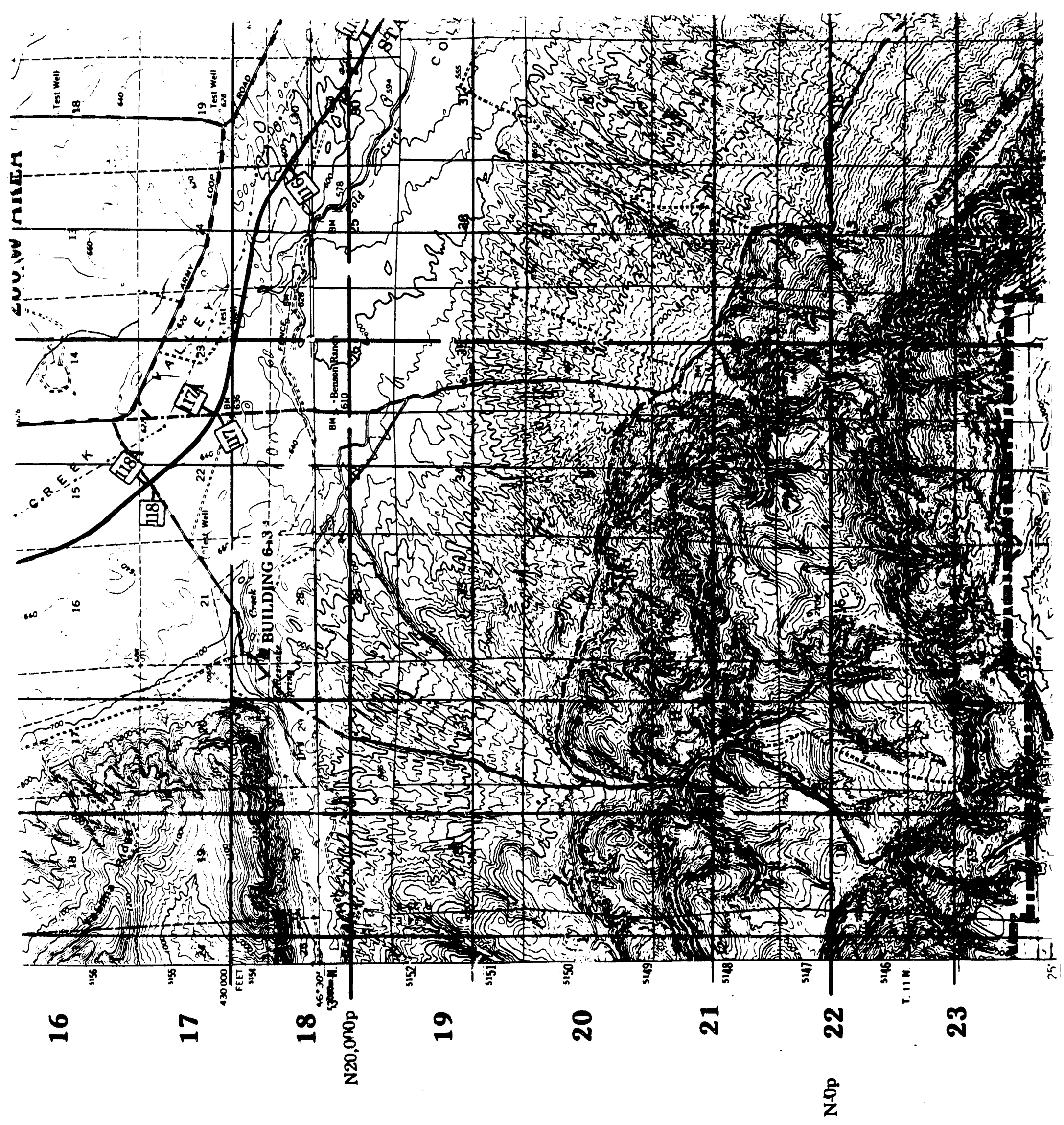




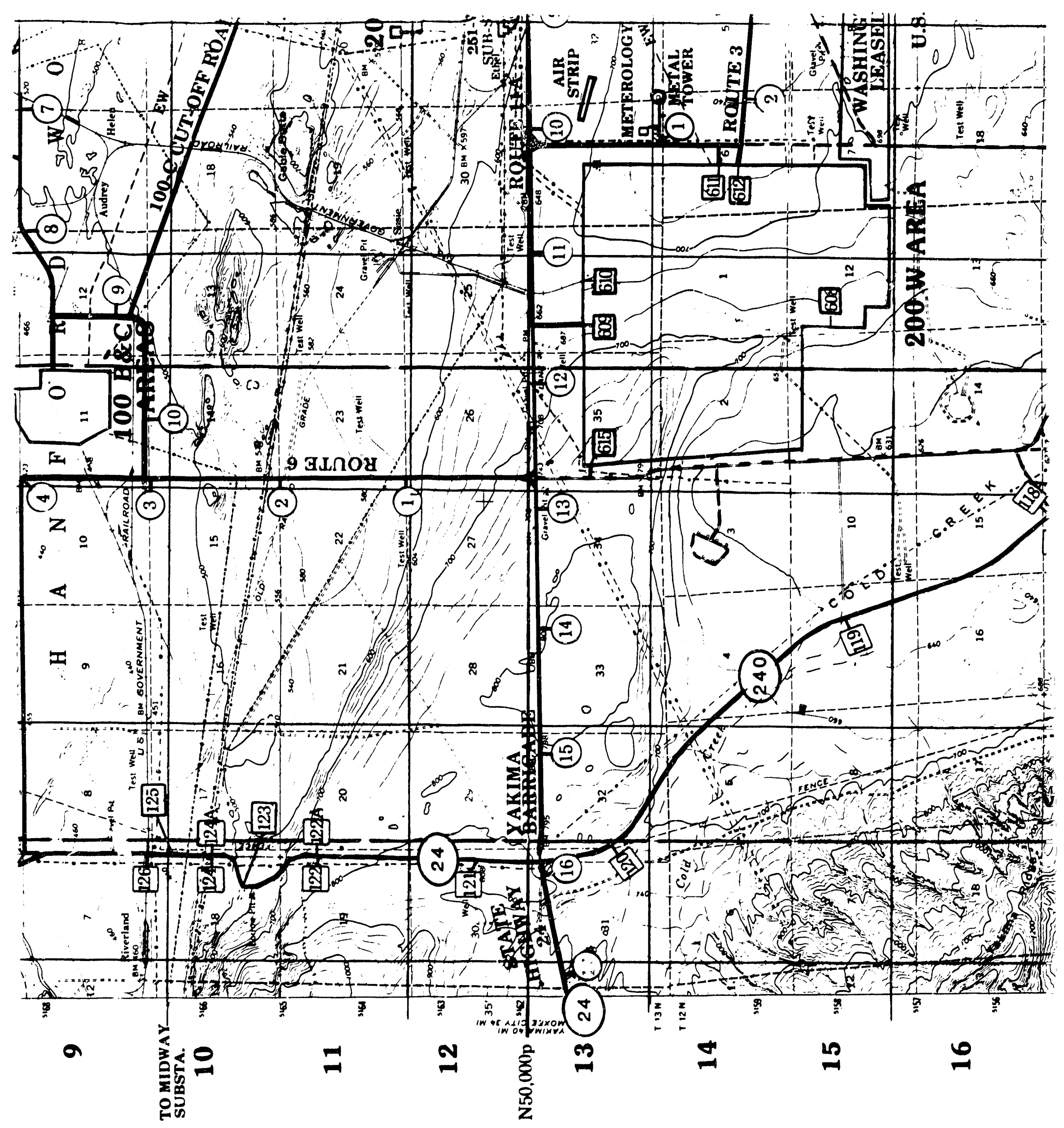




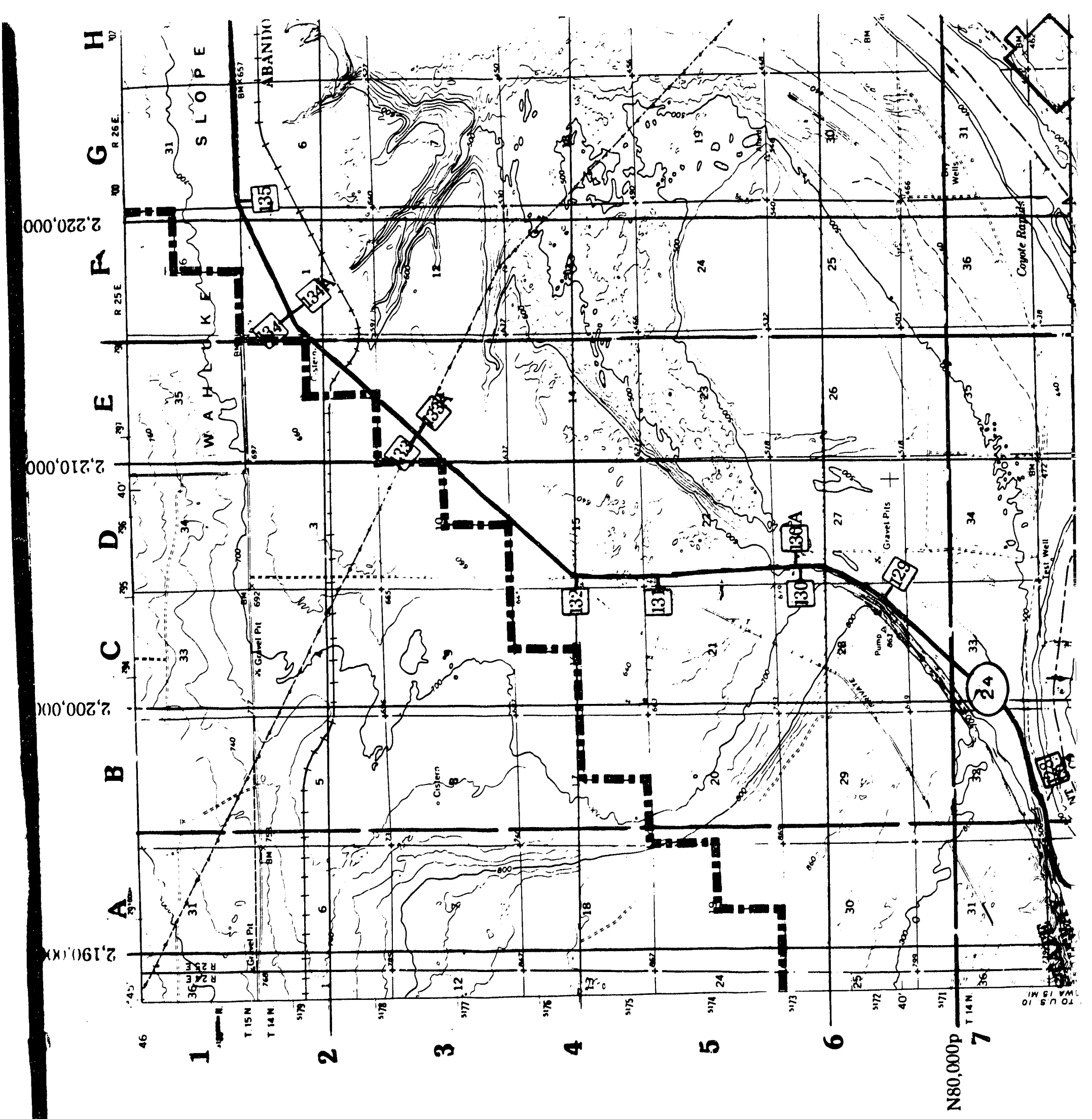









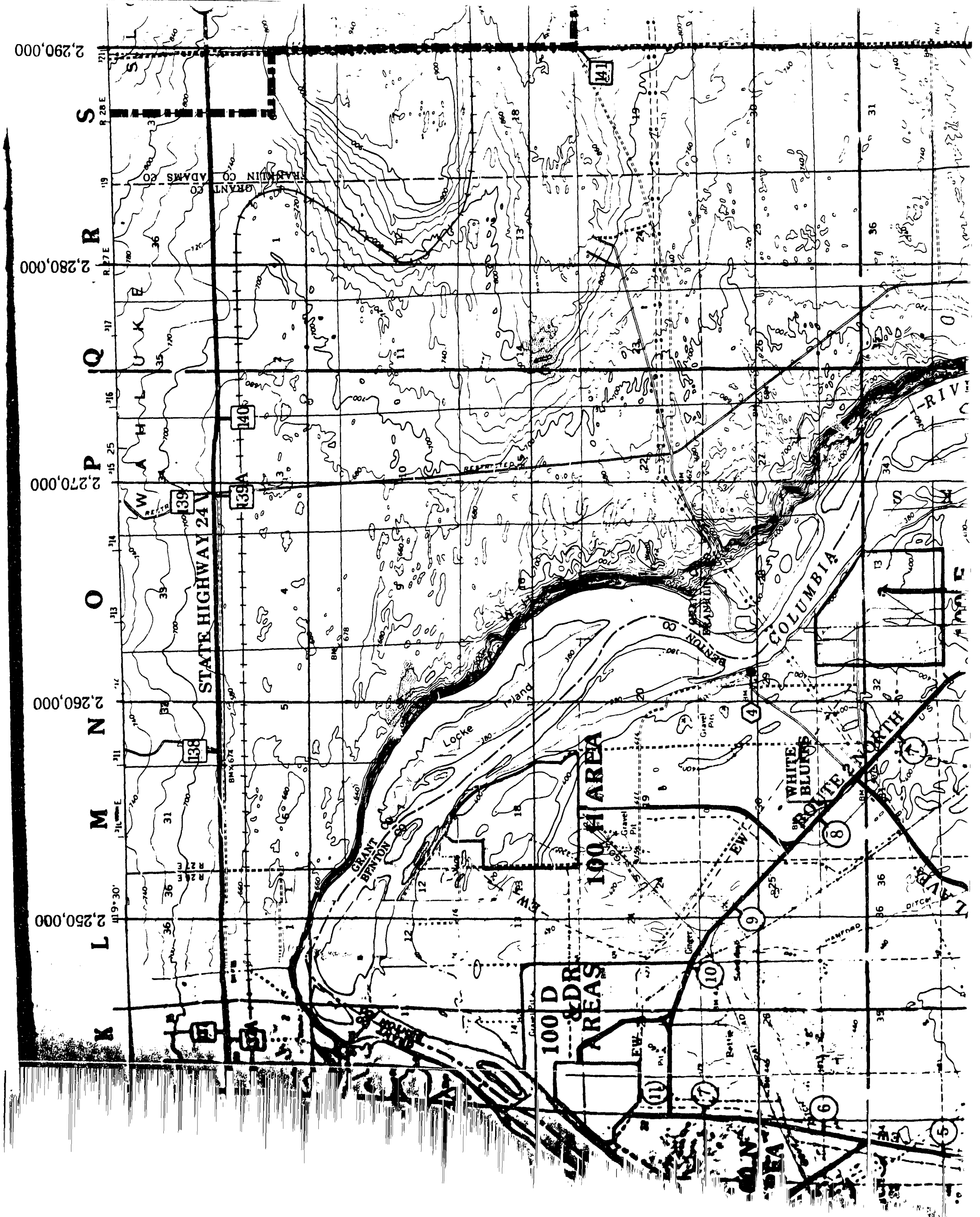




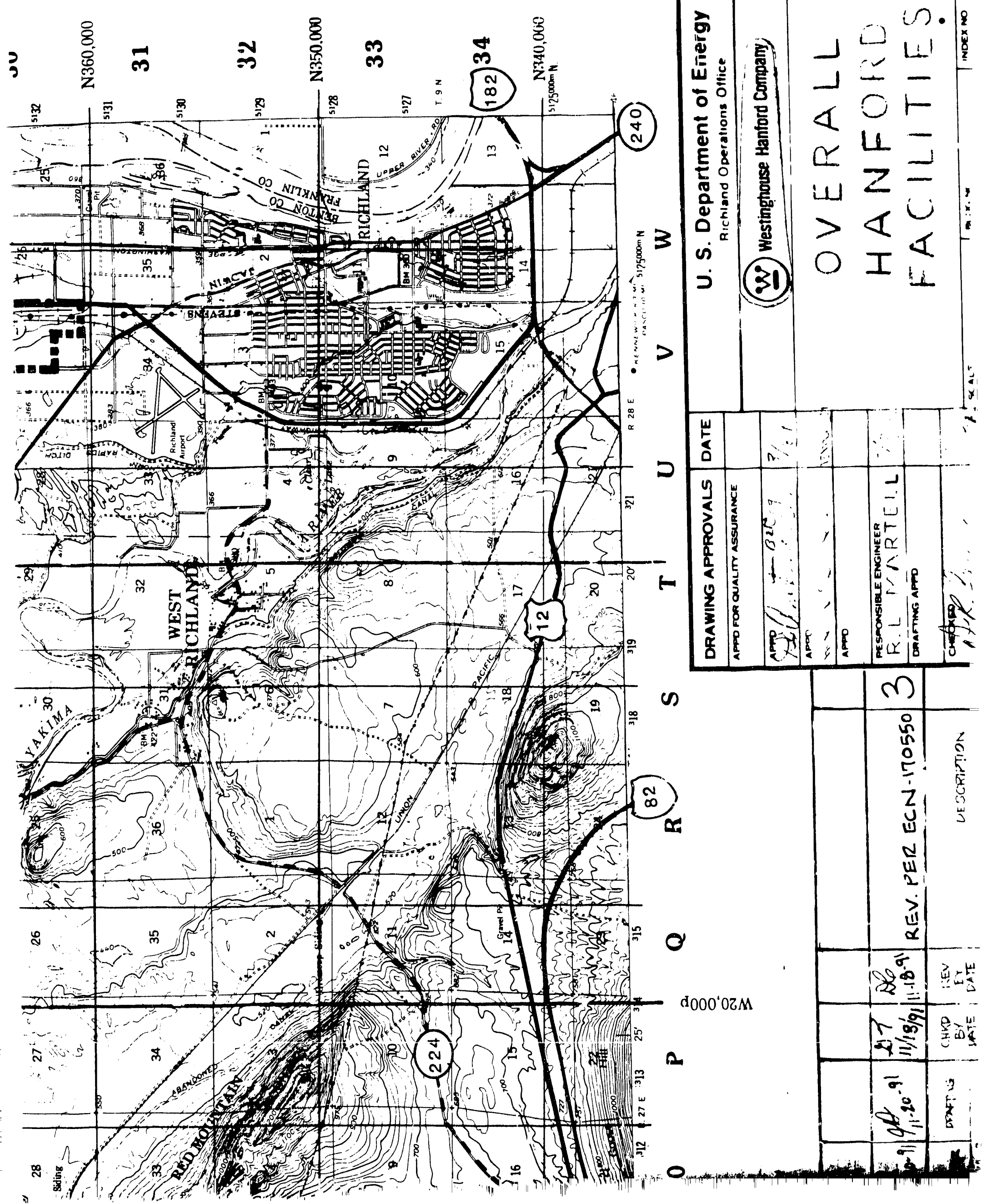




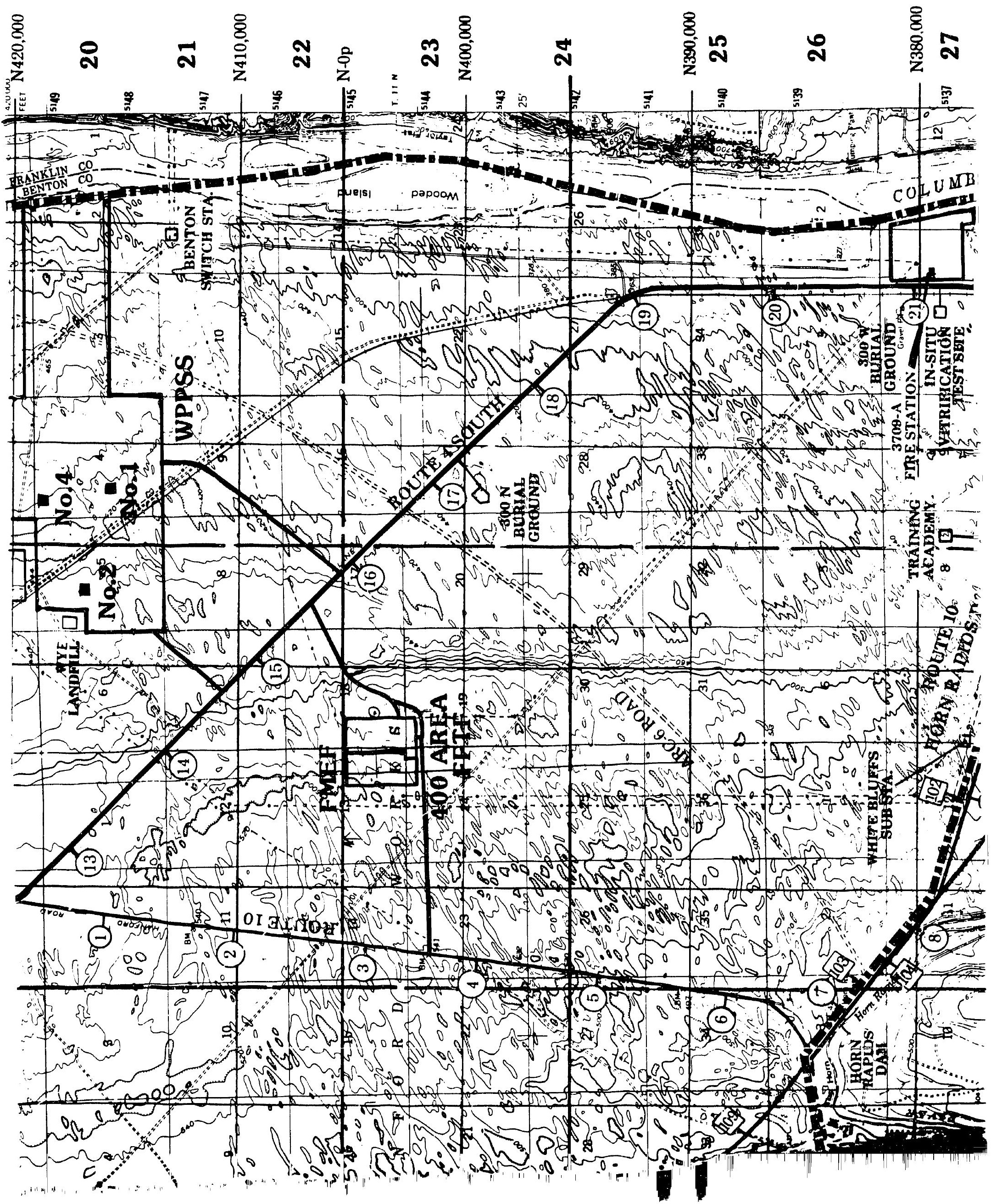




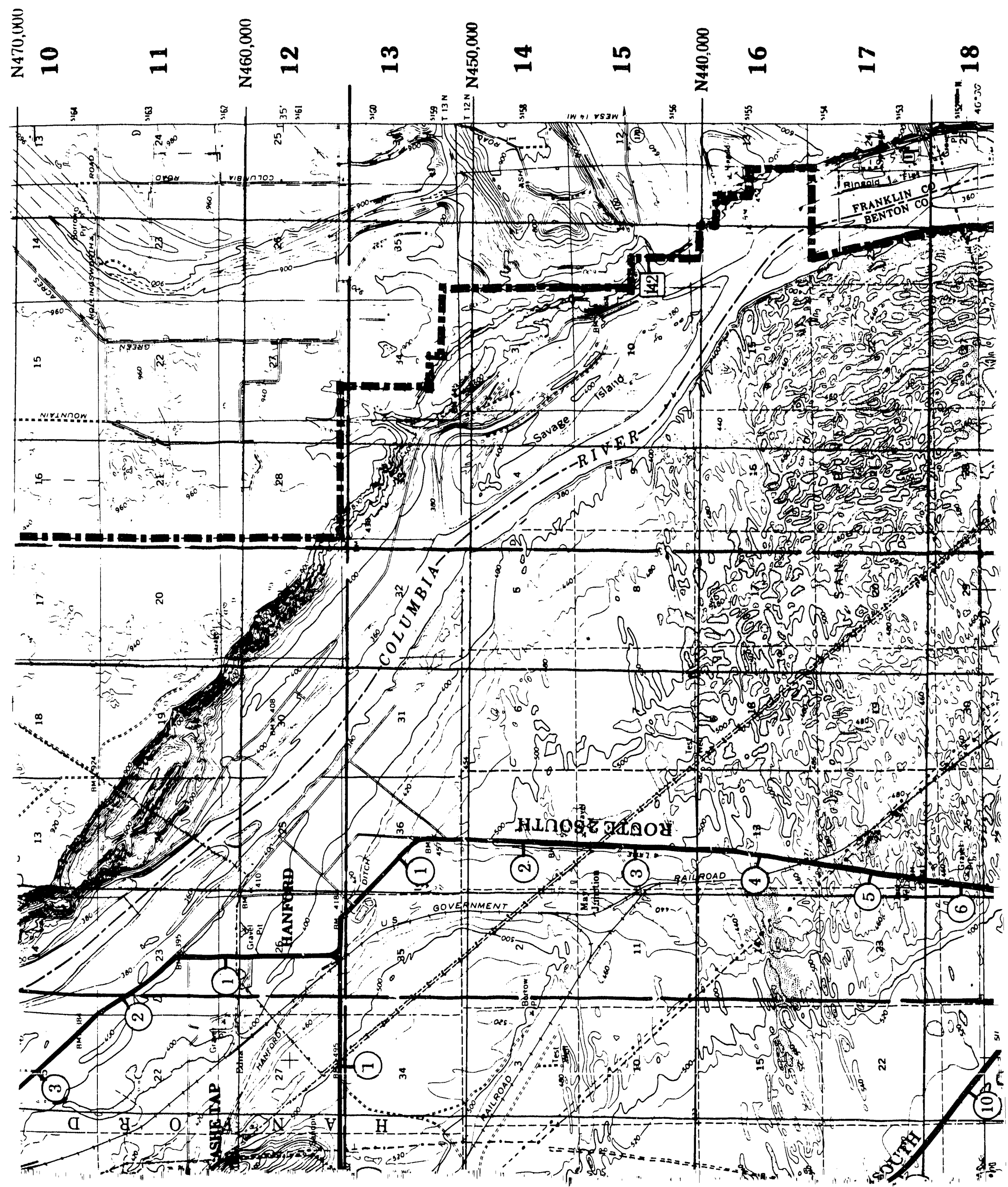




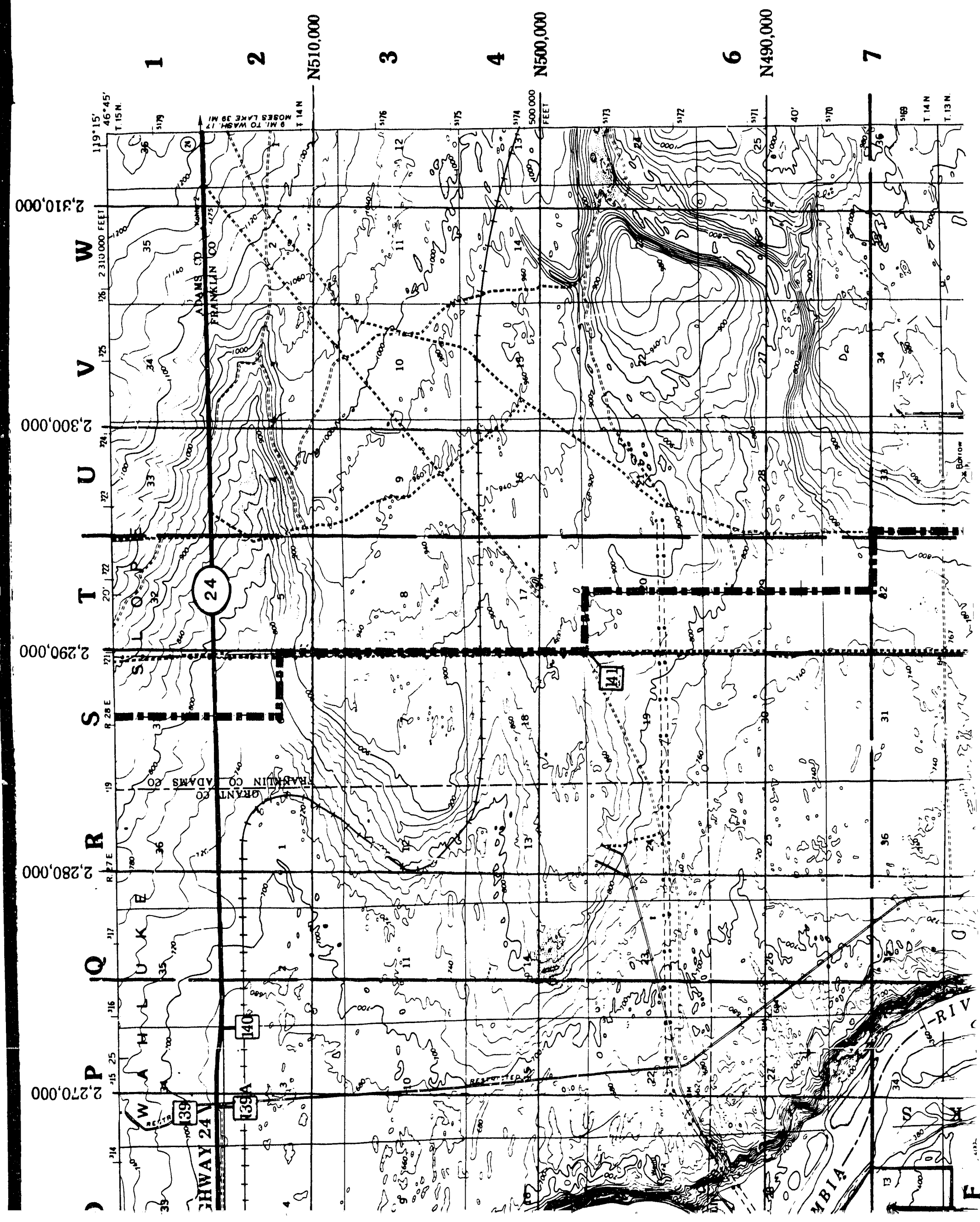


DOE/RL-90-49

Revision 0

APPENDIX B

\section{DESIGN DRAWIRGS}




\section{APPENDIX B}

\section{DESIGN DRAWINGS}

This appendix contains the following design drawings:

FSK-70E-164:

40-foot-by-40-foot Structural and Rigging Loft Building \#3 General Floor Plan (for historical reference only). Originally the 4843 AMSF Building was called Building \#3 and was used as a support building for the construction of the Fast Flux Test Facility.

\section{$H-4-152000$ :}

400 Area Layout Map, Rev. 9.

Building \#3 subsequently was moved to the present location, renamed 4843 Alkali Metal Storage Facility, and became a waste management unit for the storage of dangerous and mixed alkali metal waste generated at the Fast Flux Test Facility and from other waste generating units on the Hanford Site (H-4-152000). 

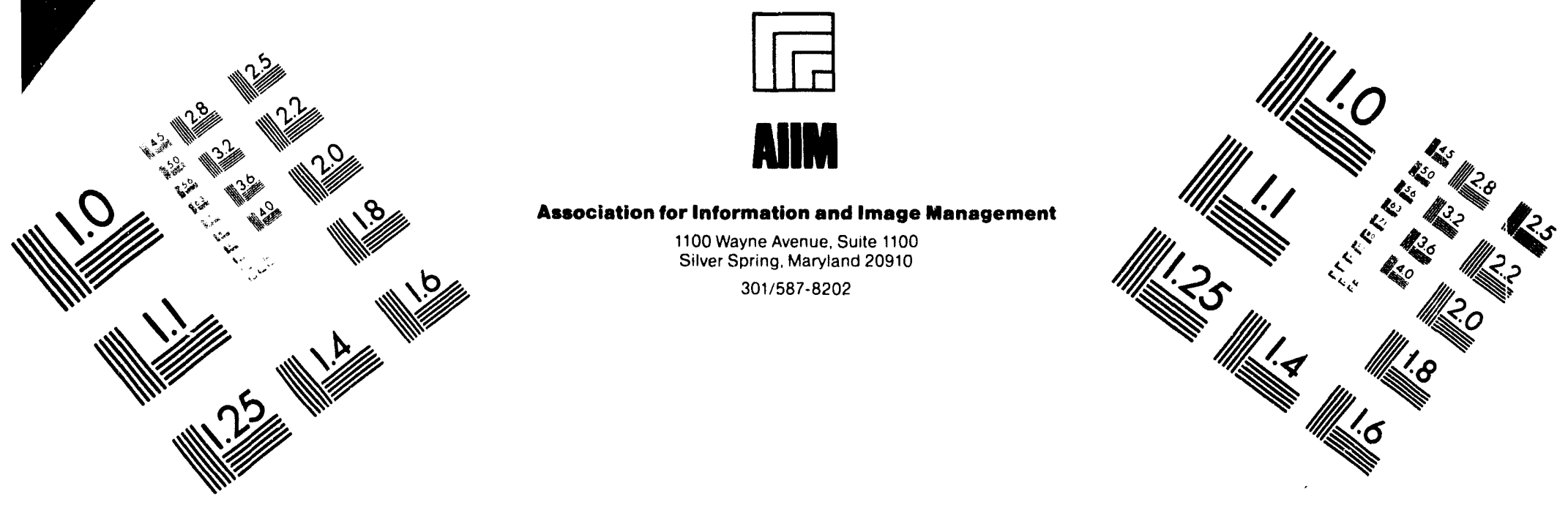

\section{Centimeter}

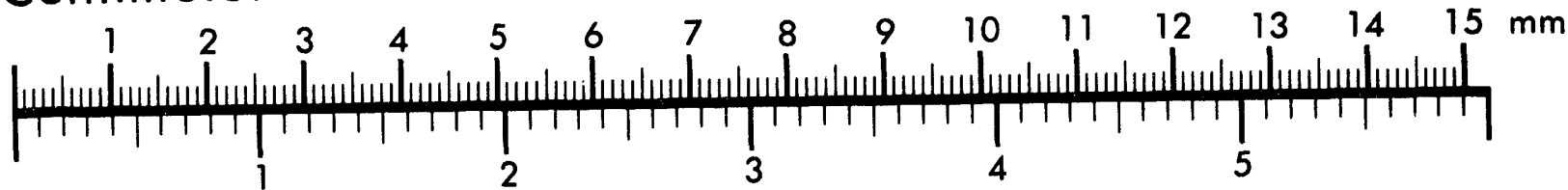

Inches
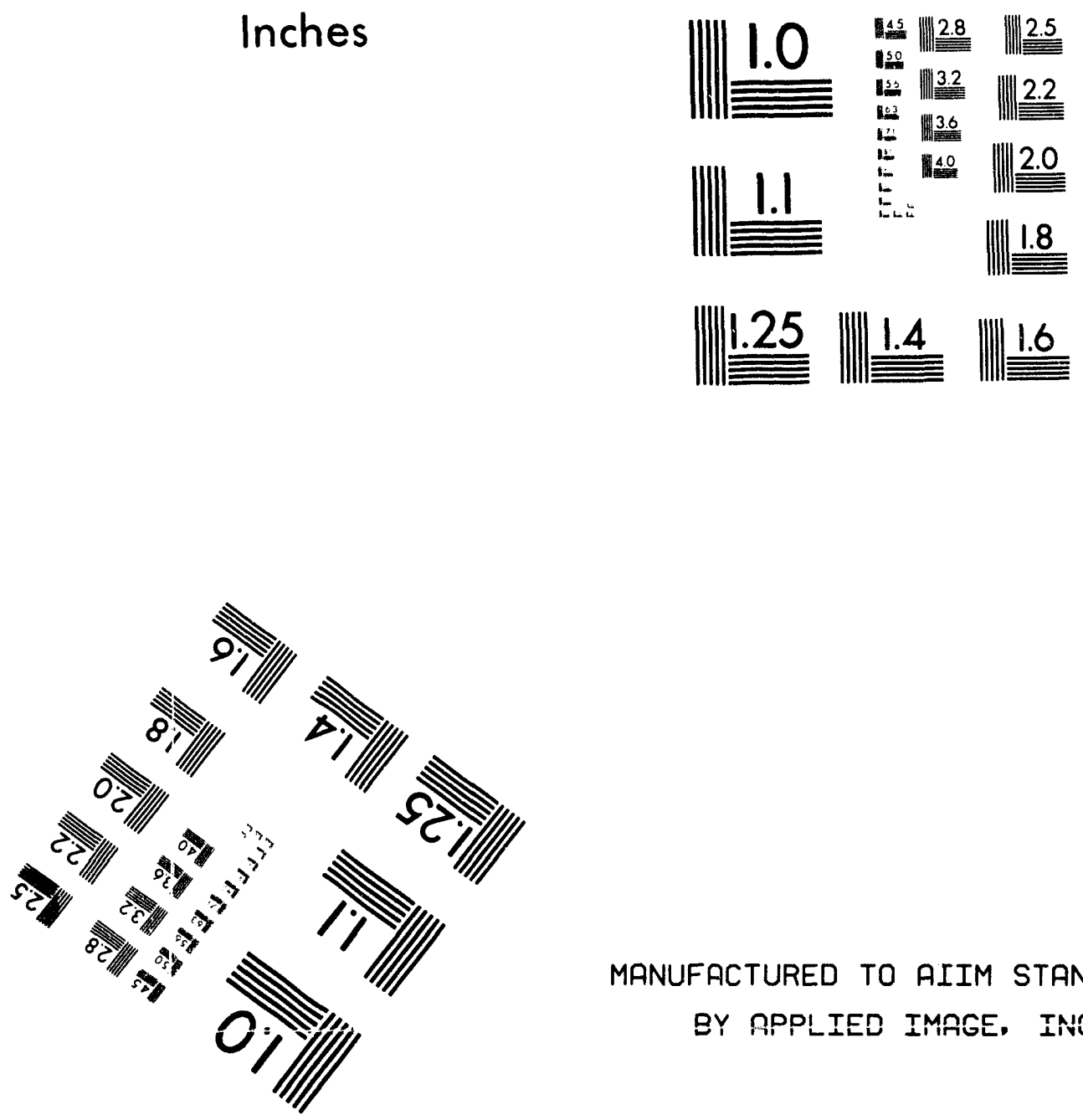

MANUFACTURED TO AIIM STANDARDS

BY RPPLIED IMAGE, INC.

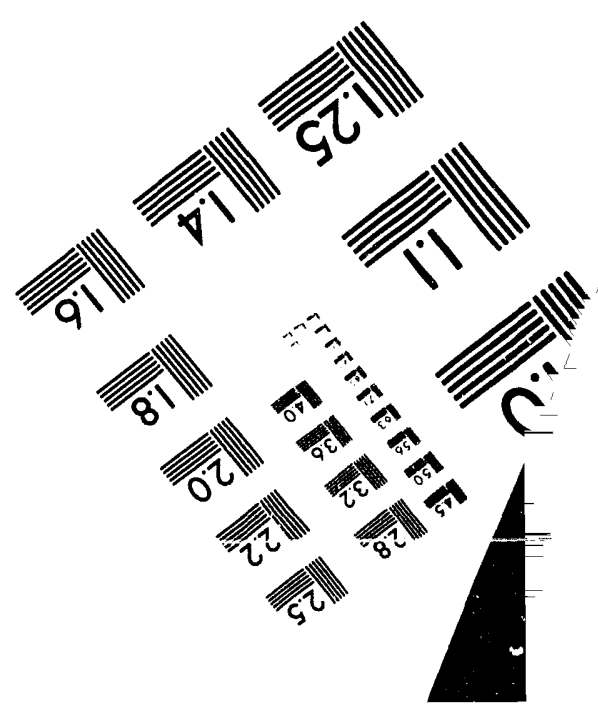



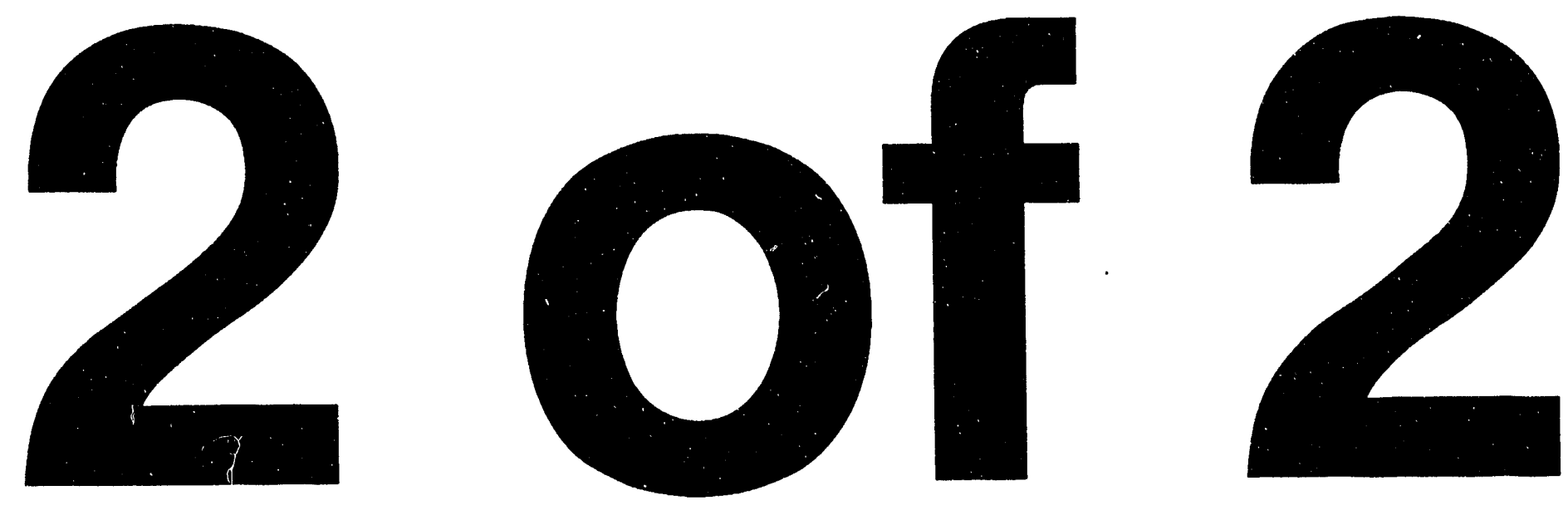
DOE/RL-90-49

Revision 0

\section{APPENDIX C}

CURRENT WASTE INVENTORY

APP $C-i$ 
DOE/RL-90-49

Revision 0

1

2

3

5

6

7

8

9

10

11

12

13

14

15

16

17

18
APPENDIX C

\section{CURRENT WASTE INVENTORY}

This appendix contains the April 1991 waste inventory for the 4843 AMSF.

Radioactive mixed waste inventory . . . . . . . . . APP C-1

Nonradioactive waste ................ APP C-11

Terms :

FFTF = Fast Flux Test Facility

NOS = not otherwise specified

LSA = low specific activity

$D M=$ drum metal

GW $=$ gross weight. 
DOE/RL-90-49

Revision 0
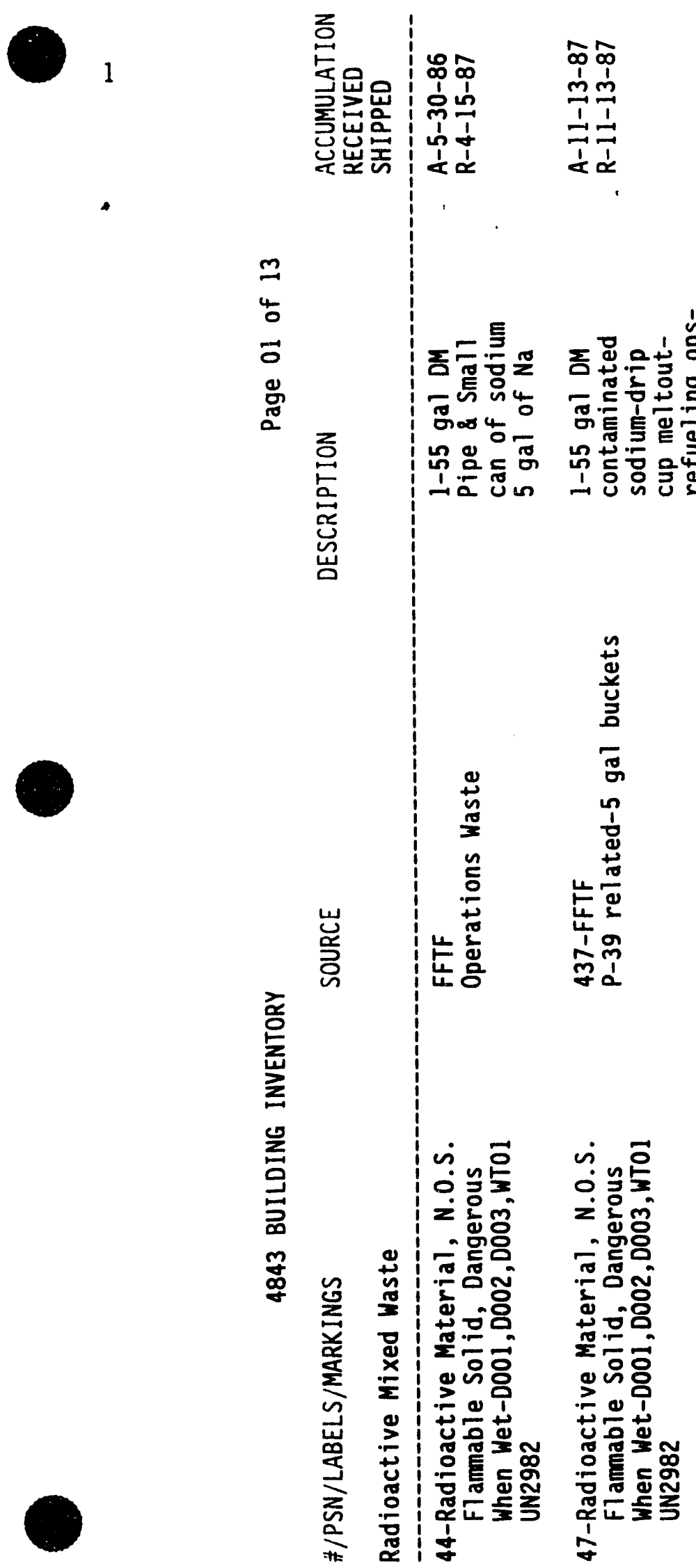

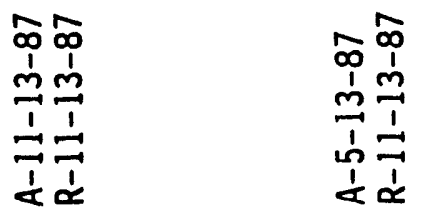

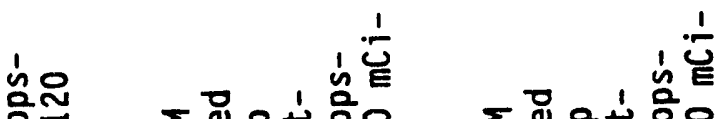

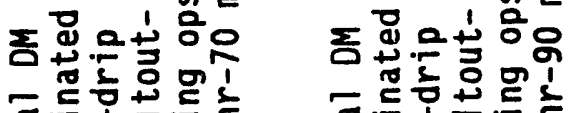

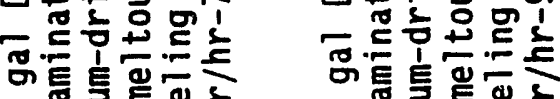

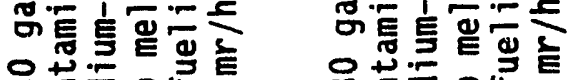

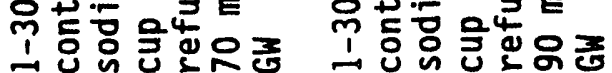
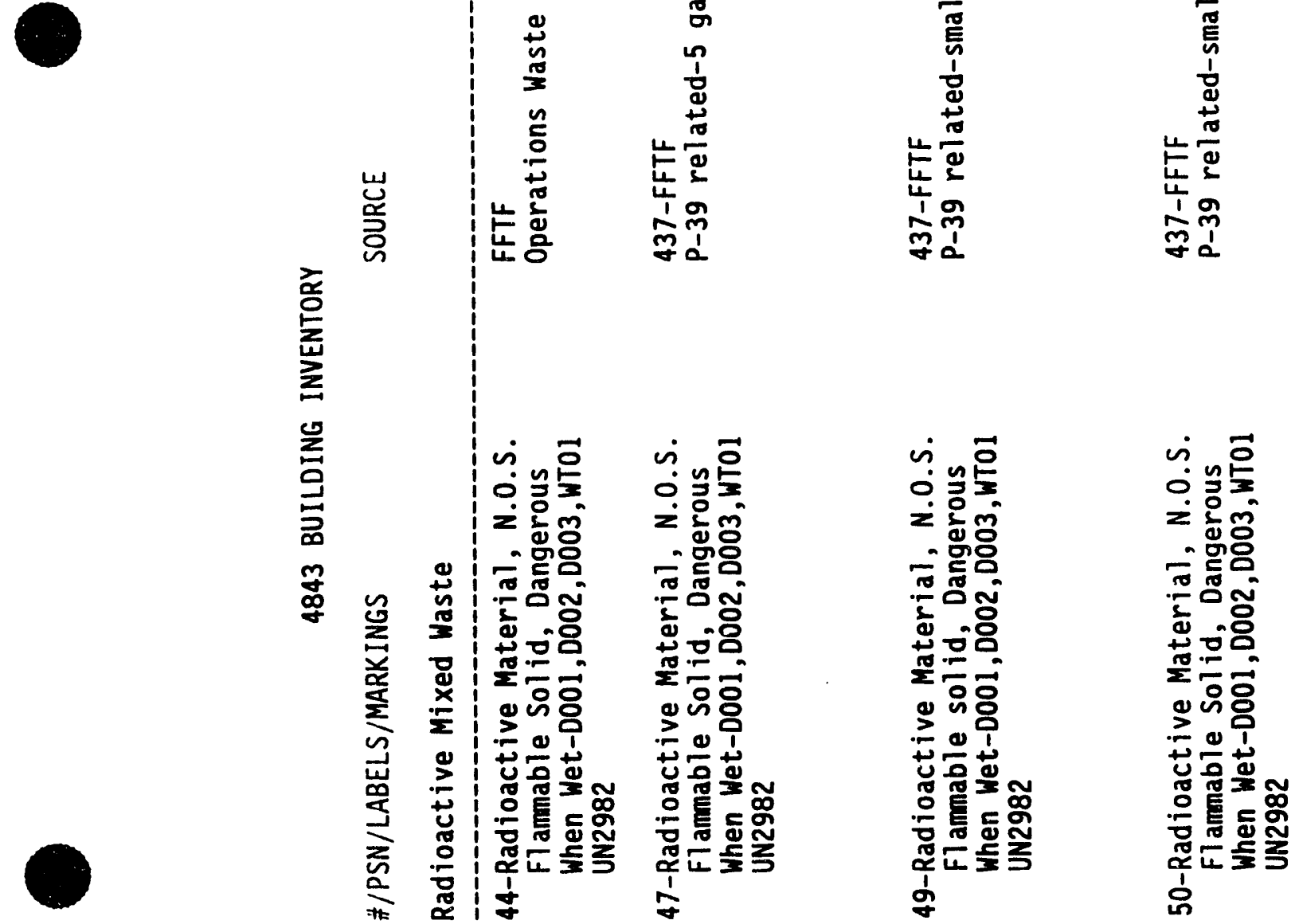
DOE/RL-90-49

Revision 0

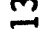

4 क

ช $\stackrel{1}{m} m$

品 $\stackrel{1}{\frac{1}{2}} \frac{1}{2}$

$\infty$

1

$\frac{1}{1} \frac{1}{1}$

$\begin{array}{cc}0 & 0 \\ 0 & 1 \\ 1 & \frac{1}{1} \\ 0 & \frac{1}{1} \\ 1 & \frac{1}{7} \\ 1 & 1 \\ 1 & 1\end{array}$

$\infty \longdiv { \infty }$

을

$\frac{1}{1} \frac{1}{1}$

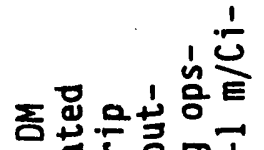

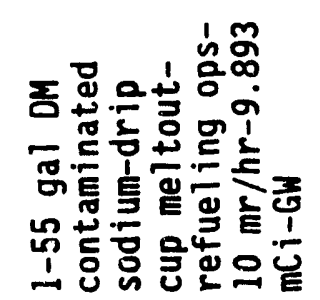

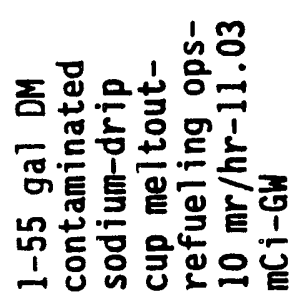

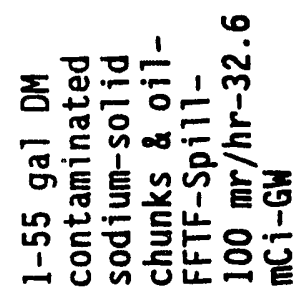

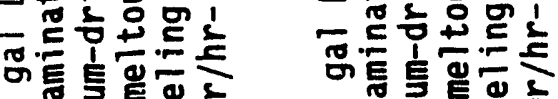

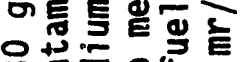

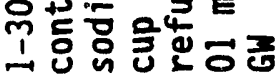

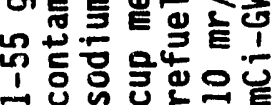

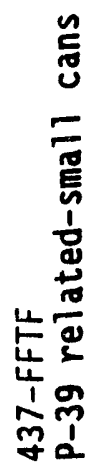

䓠

气ิ

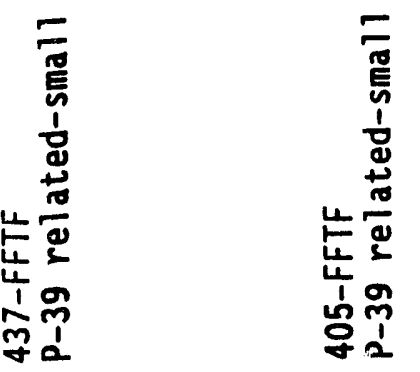

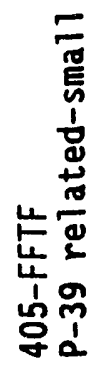

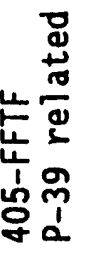
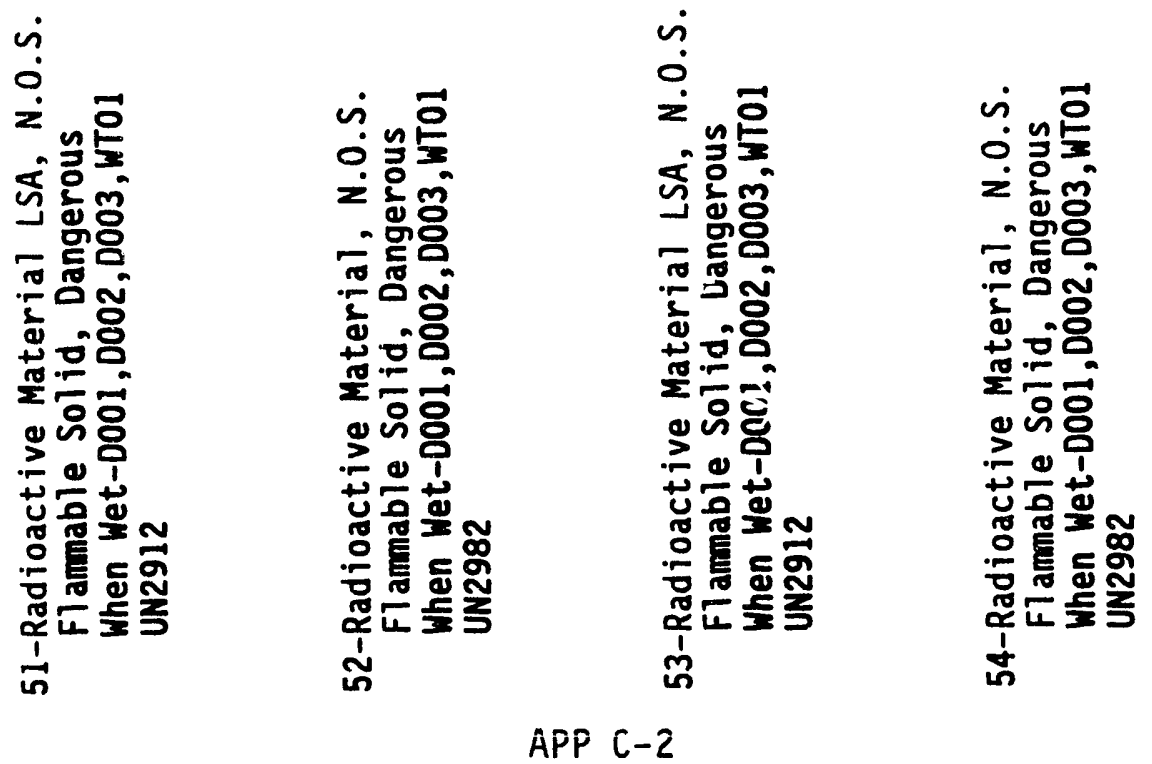

APP C -2 
DOE/RL-90-49

Revision 0

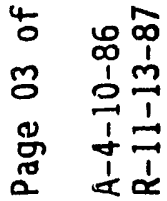

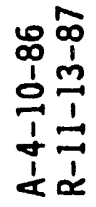

\begin{tabular}{ll}
$\infty$ & $\infty$ \\
0 & 1 \\
1 & $\frac{m}{0}$ \\
\hdashline & $\frac{1}{1}$ \\
$\frac{1}{1}$ & $\frac{1}{2}$
\end{tabular}

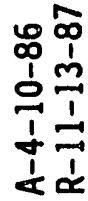

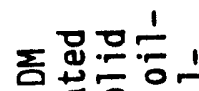

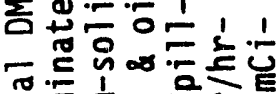

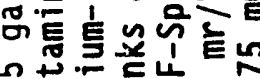

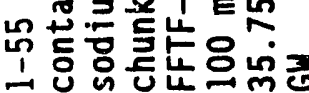

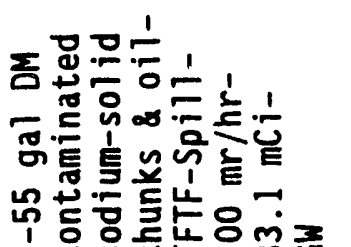

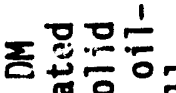

-

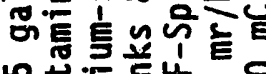

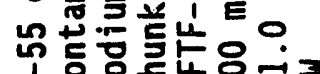

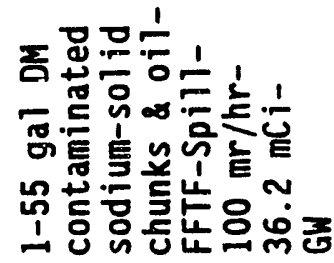

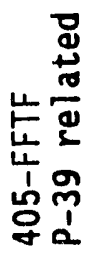

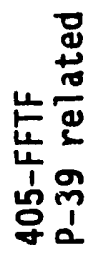

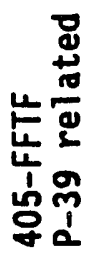

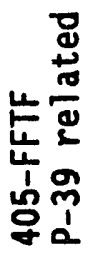
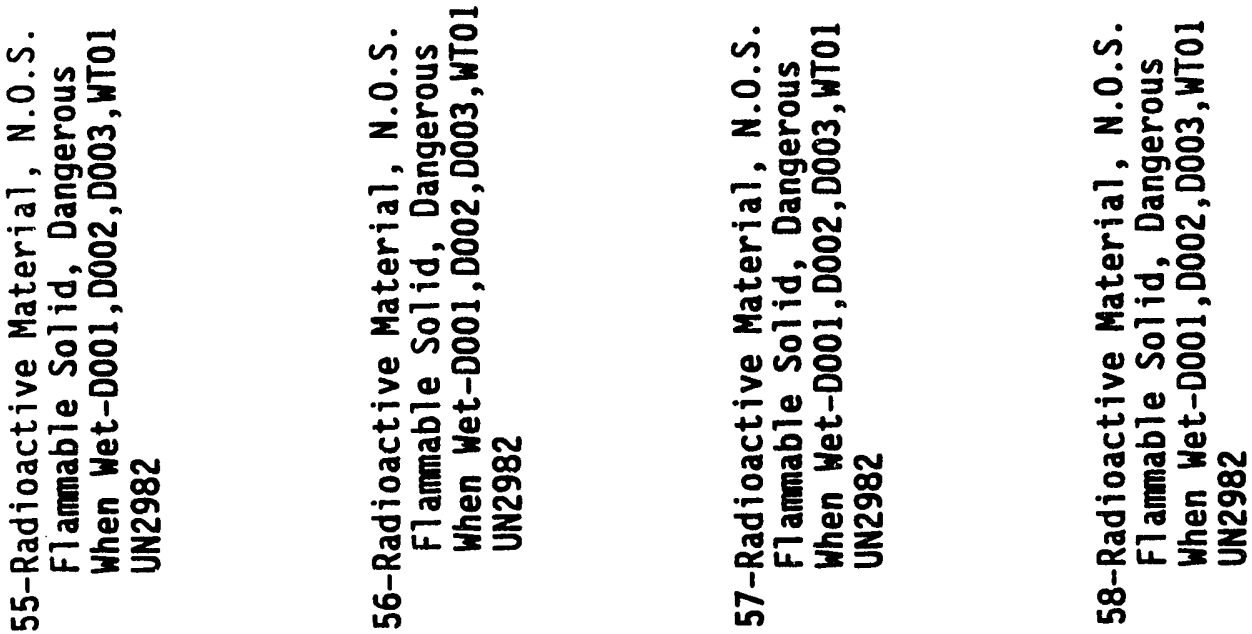


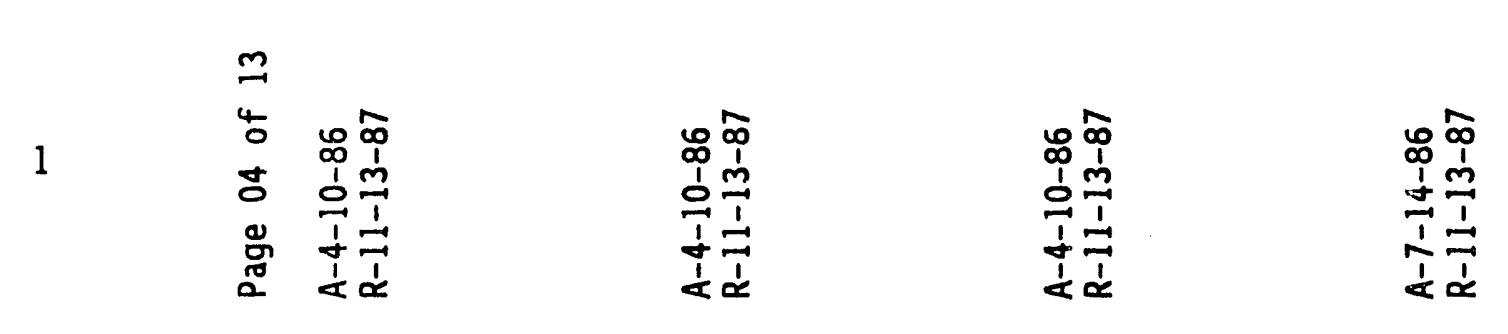

DOE/RL-90-49

Revision 0

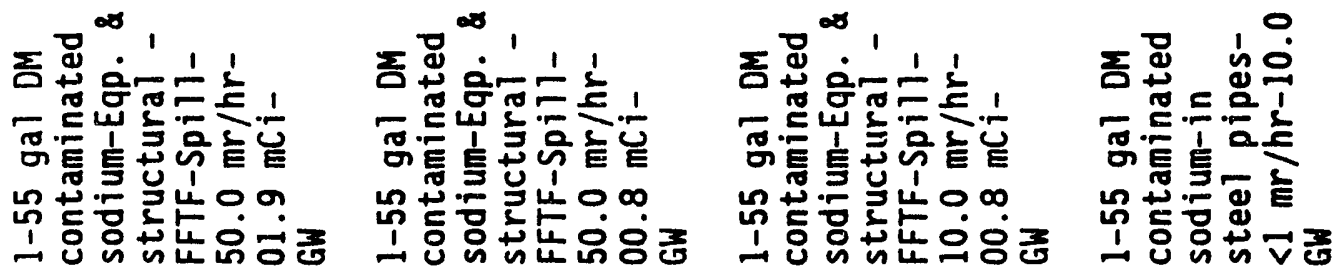
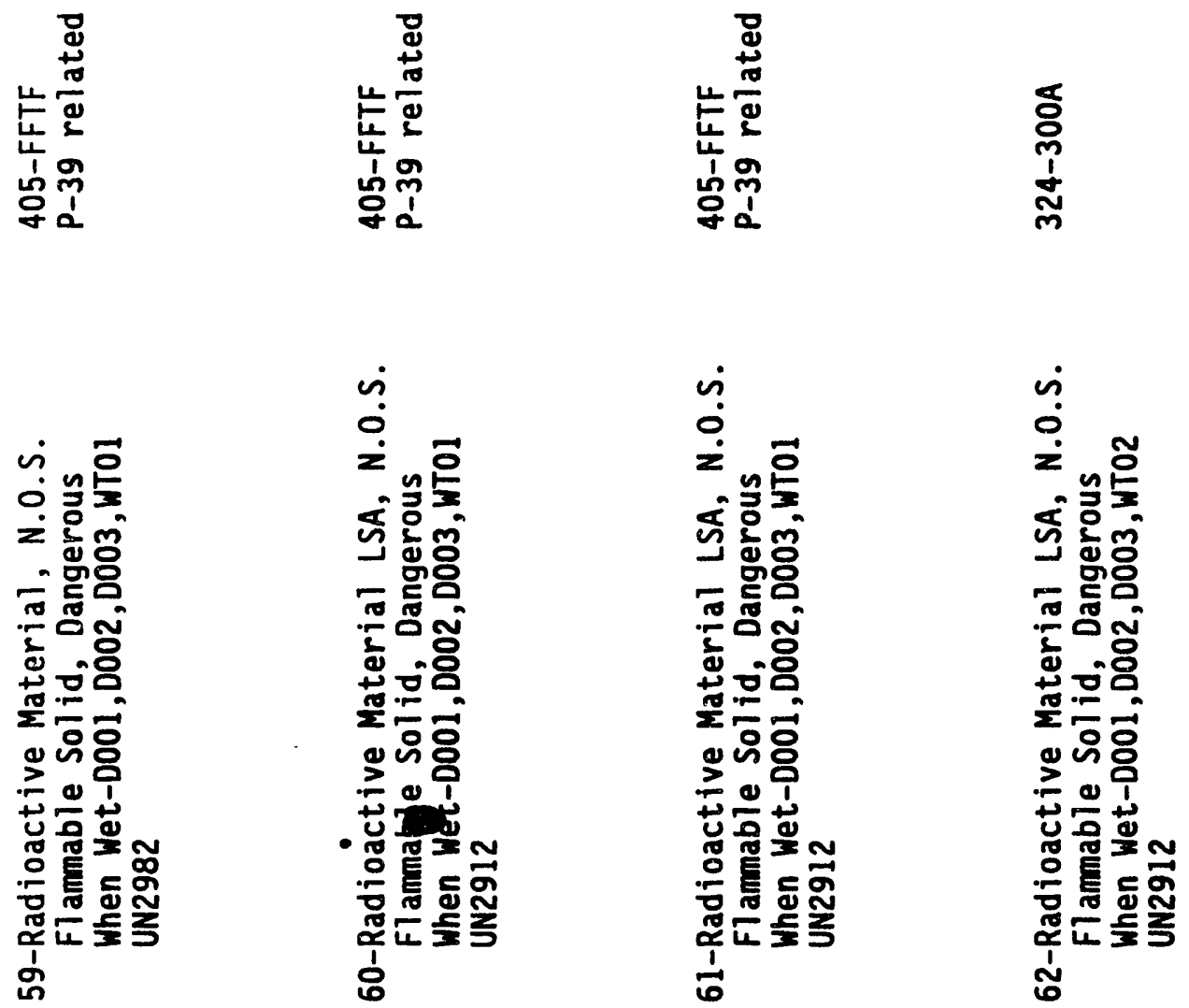

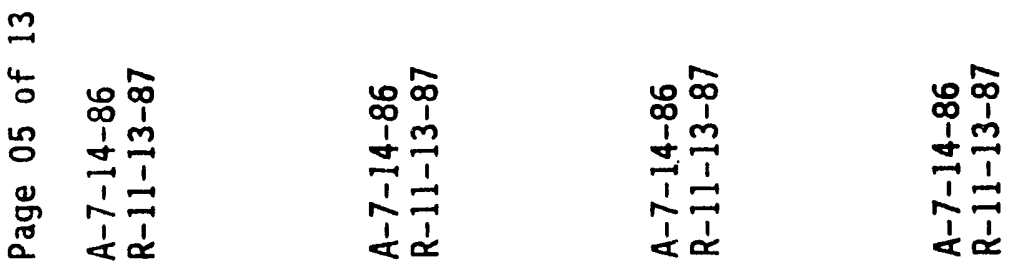

$\begin{array}{ll}0 & 0 \\ \infty & 1 \\ 1 & \frac{1}{7} \\ 1 & \frac{1}{1} \\ & \frac{1}{2}\end{array}$
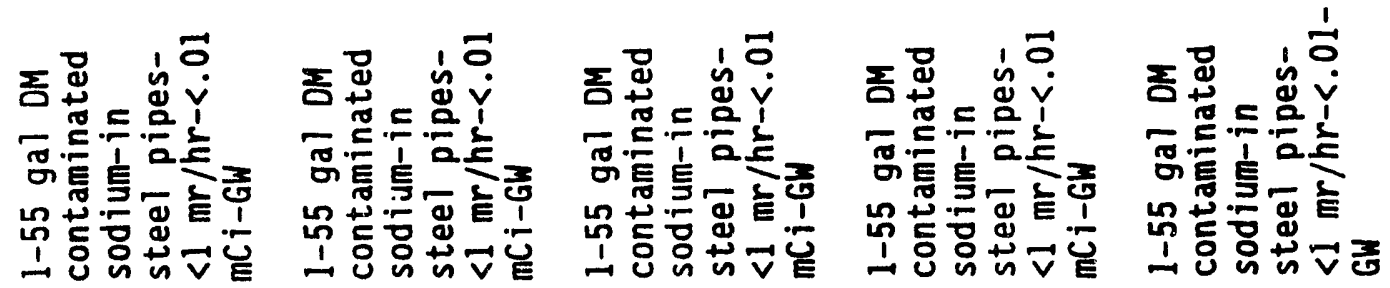

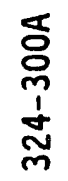

్ㅗㅇ

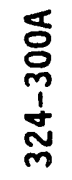

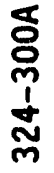

్ㅗㅁ
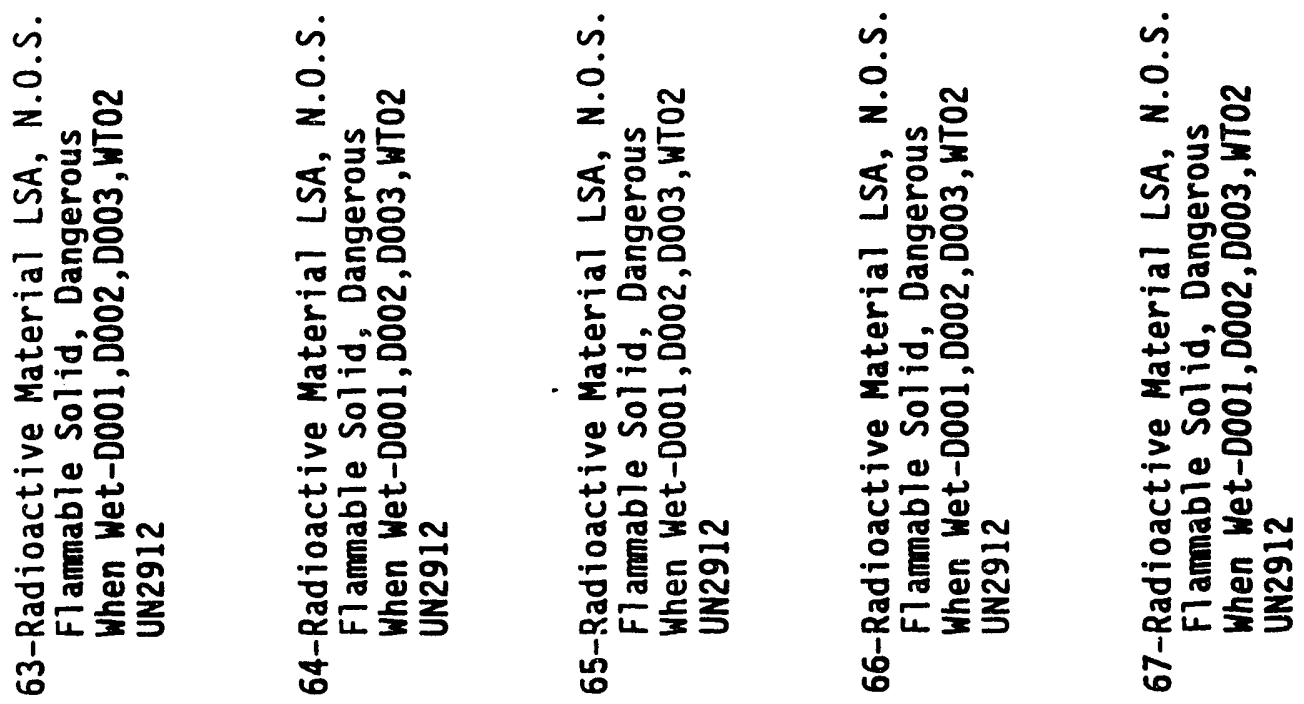


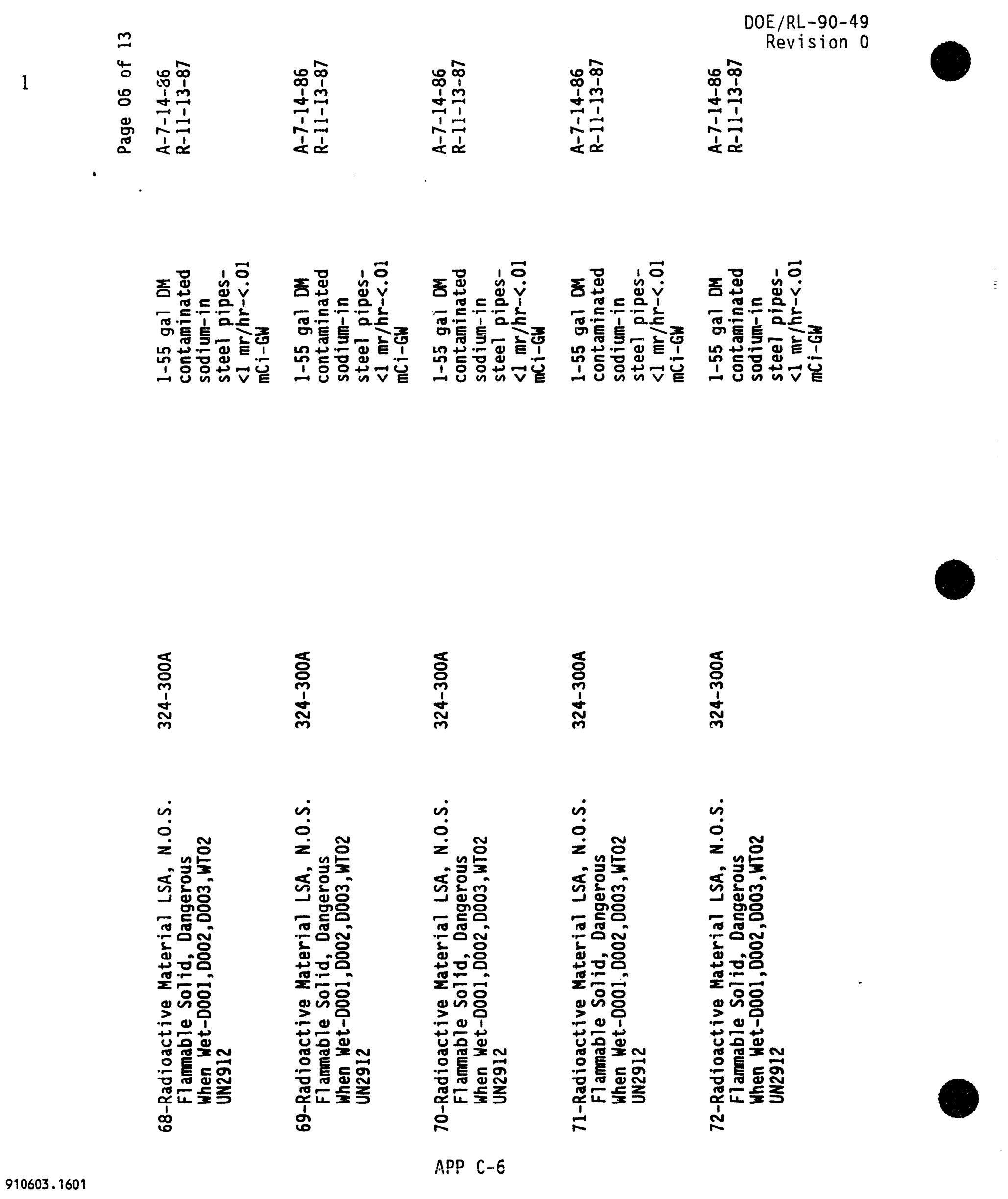


DOE/RL-90-49

Revision 0

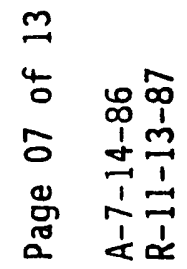

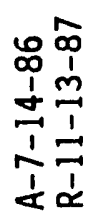

$\begin{array}{ll}0 & 0 \\ 0 & 1 \\ 1 & m \\ 4 & \frac{m}{1} \\ 1 & \frac{1}{1} \\ \frac{1}{2} & \frac{1}{\alpha}\end{array}$

$\begin{array}{ll}0 & 0 \\ 0 & 1 \\ 1 & m \\ 1 & \frac{1}{1} \\ 1 & \frac{1}{1} \\ 1 & \frac{1}{2}\end{array}$

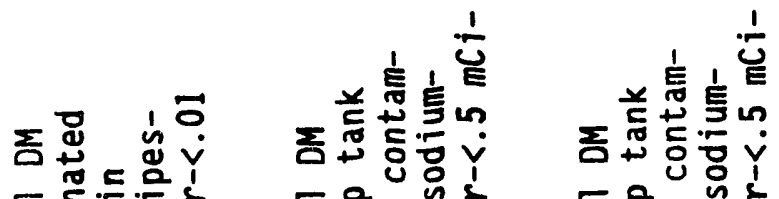

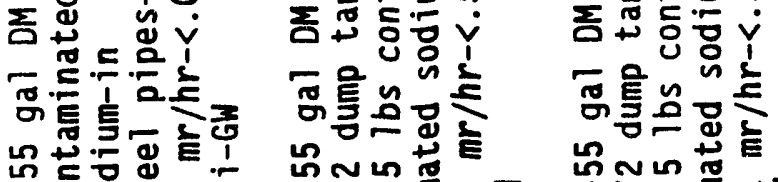

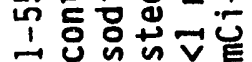

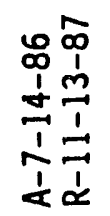
นก๊他苯
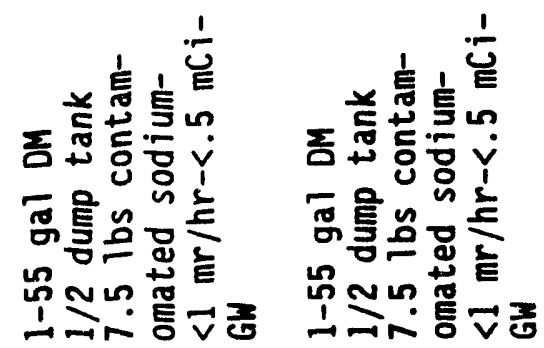

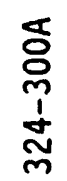

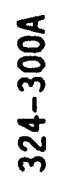

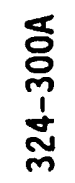

离

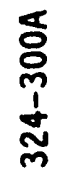
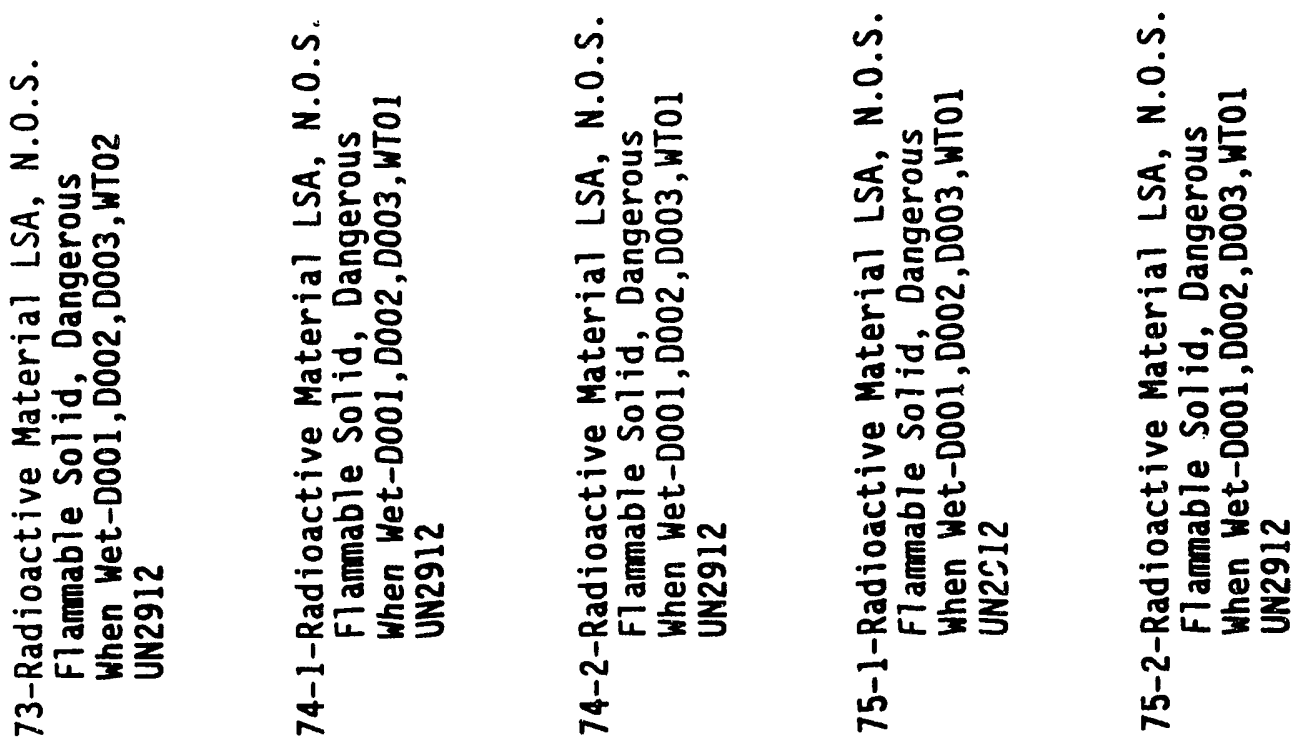
DOE/RL-90-49

Revision 0

m

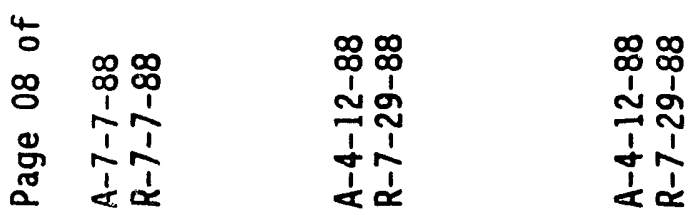

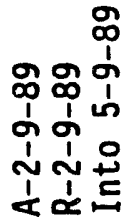

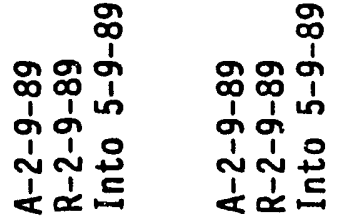

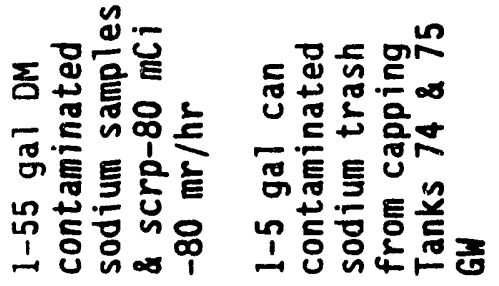

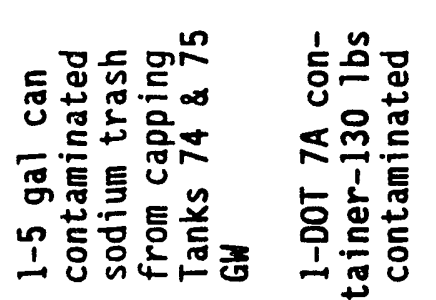

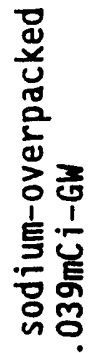

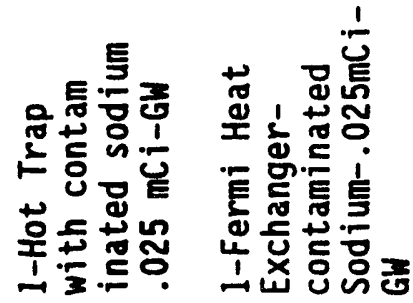

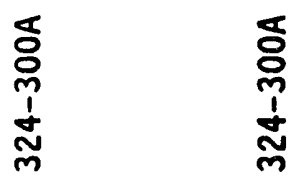

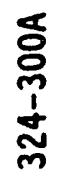

్ㅗㄹ

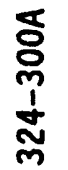

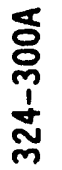
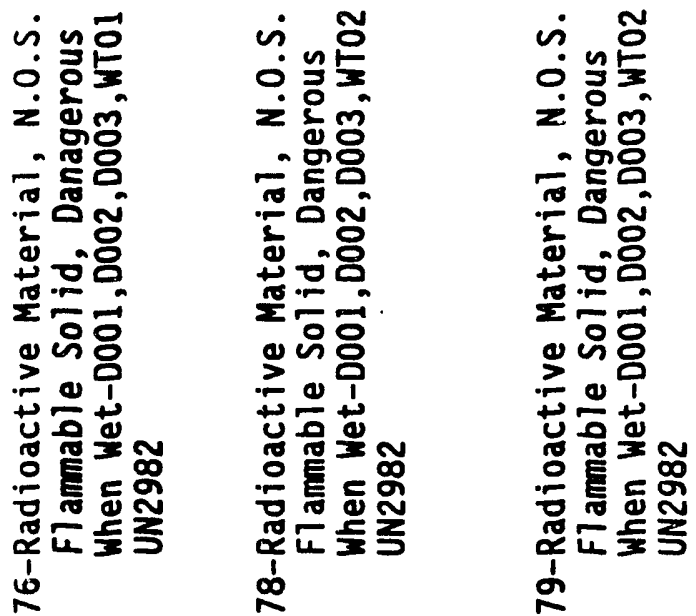

نं

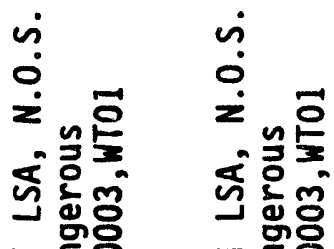

T 잉

氙

ธ

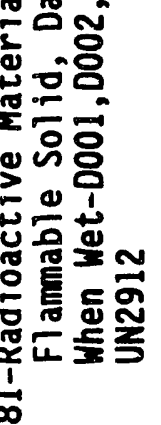

뚱

둘용

ث્ㅇㅇㅛ

$\geqslant$

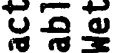

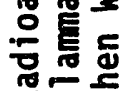

跴至

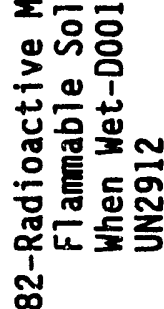


DOE/RL-90-49

Revision 0

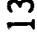

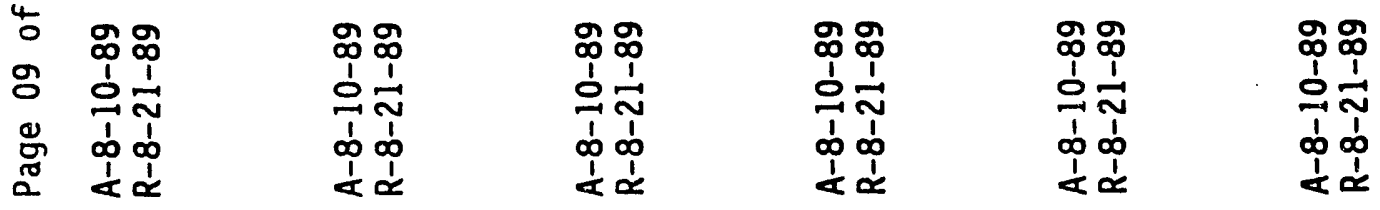

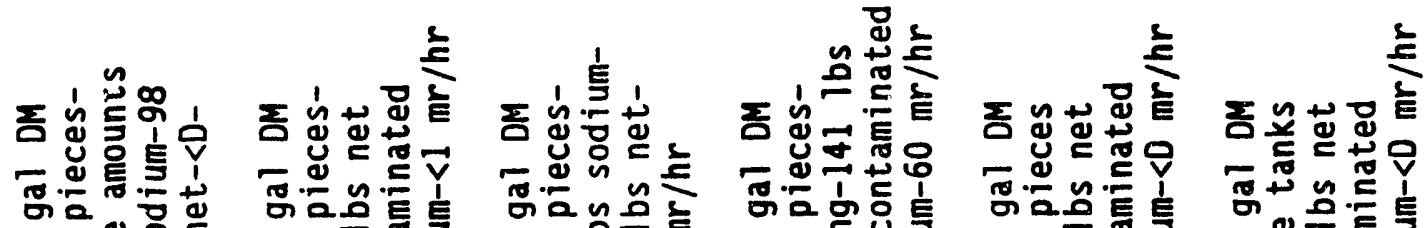

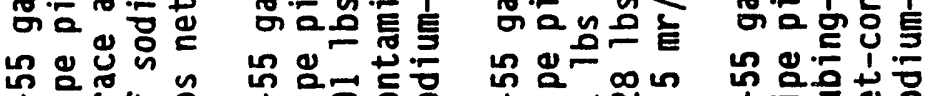

กึ. ํㅡㄴ

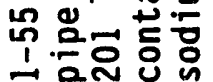

นم

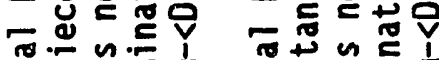

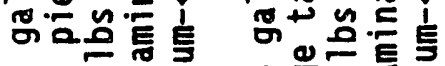

un

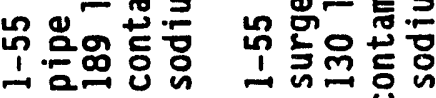

\begin{abstract}
-avㅇํ
\end{abstract}

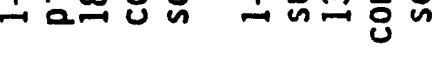

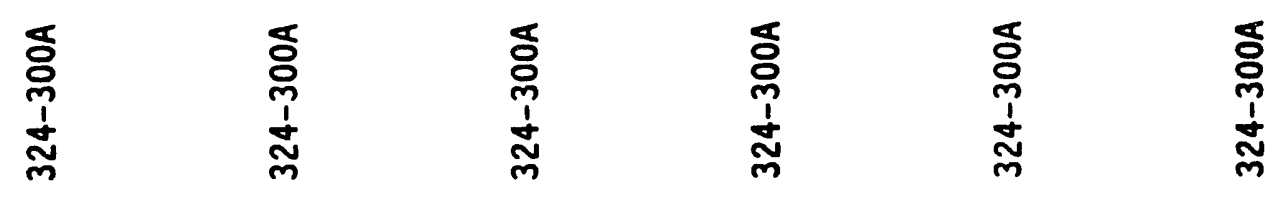
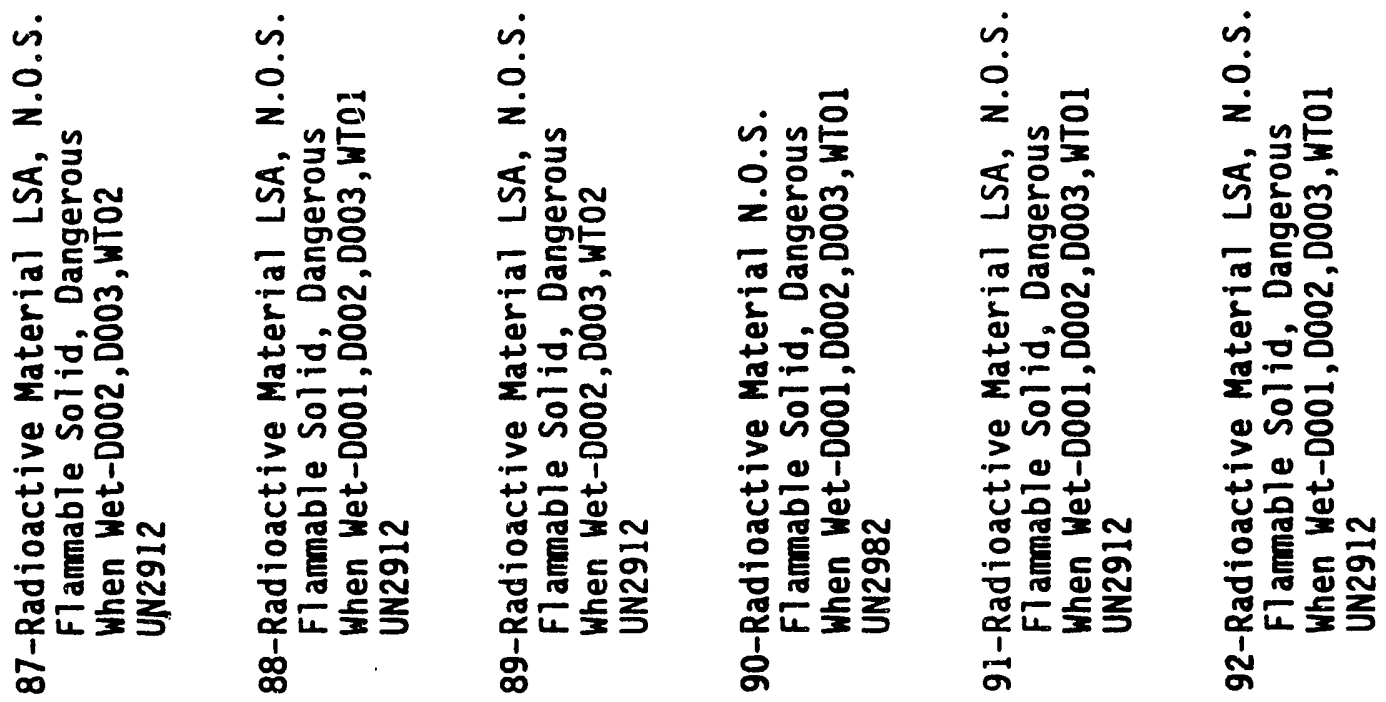
$m$

DOE/RL-90-49

Revision 0

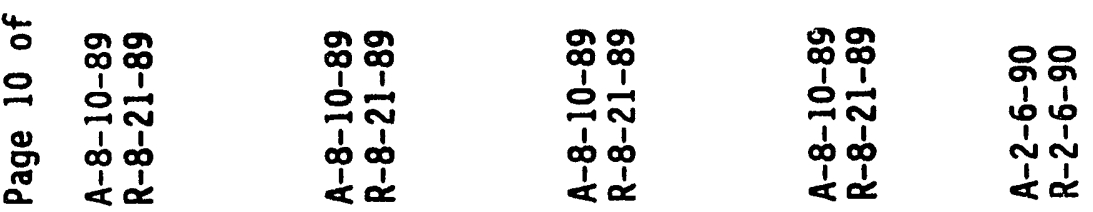

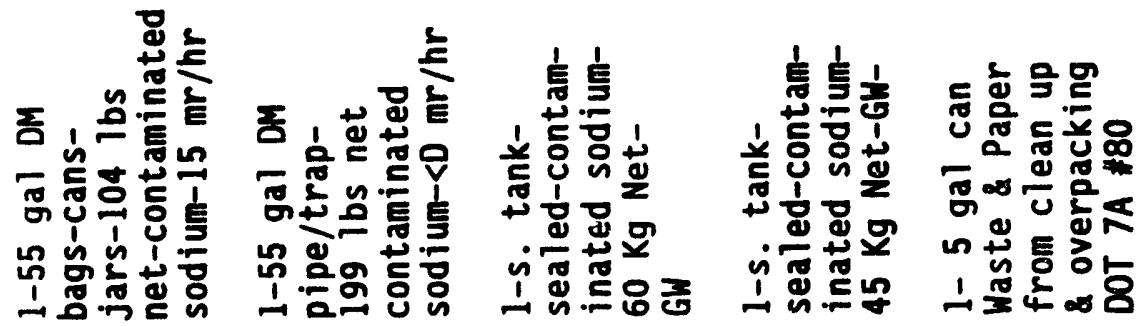

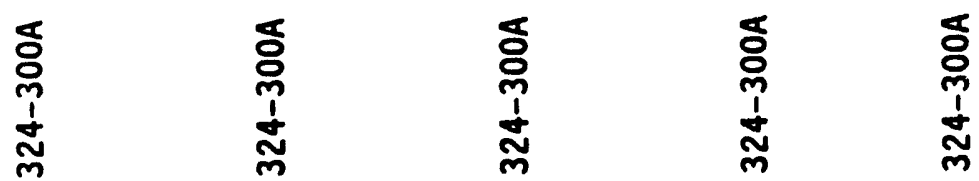
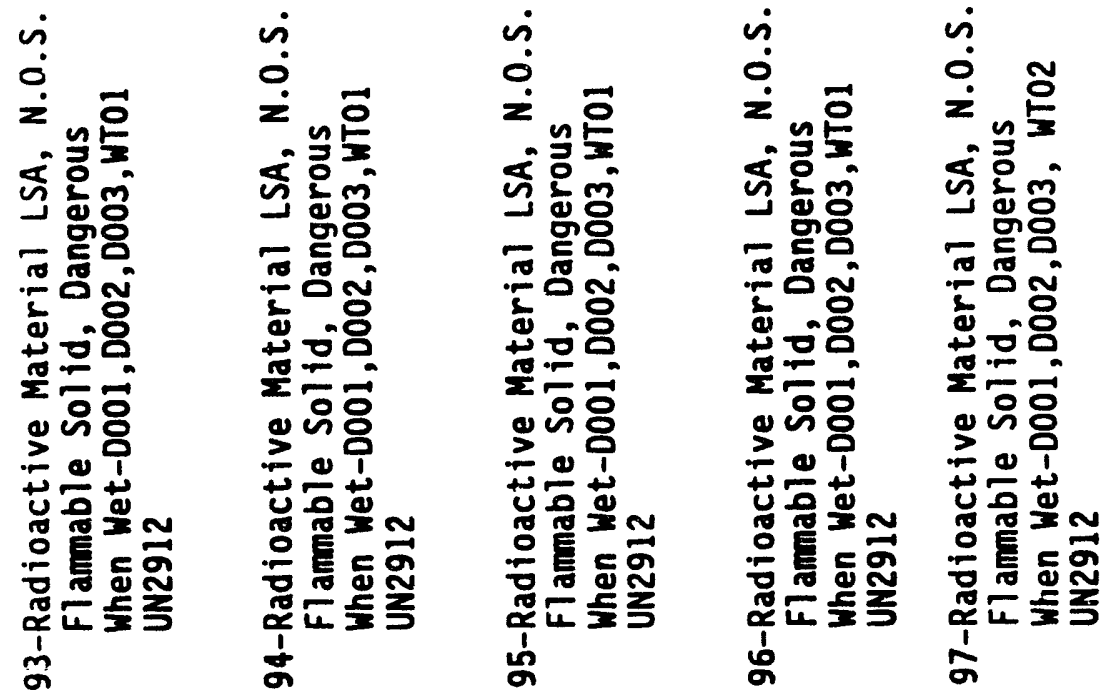


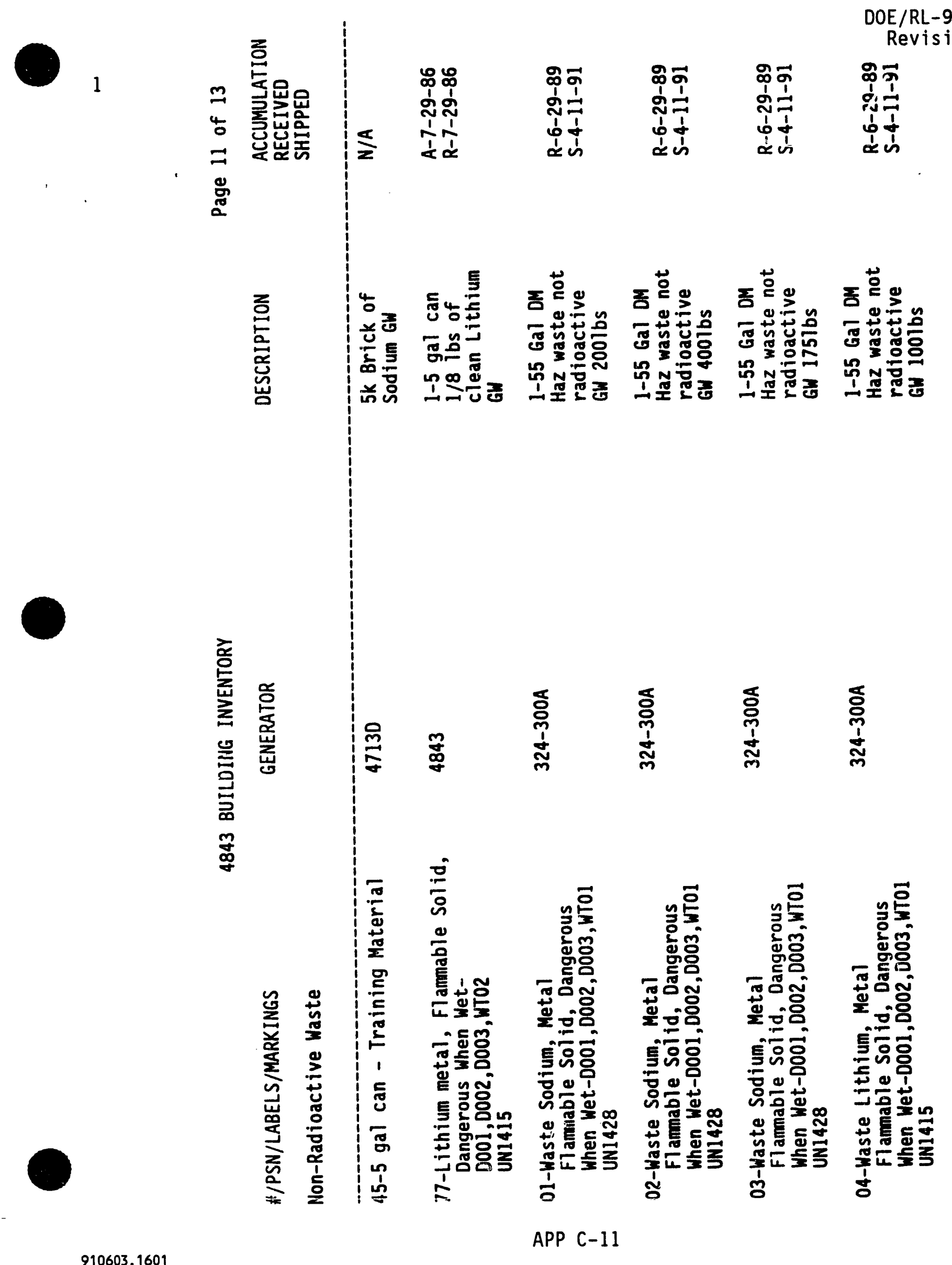




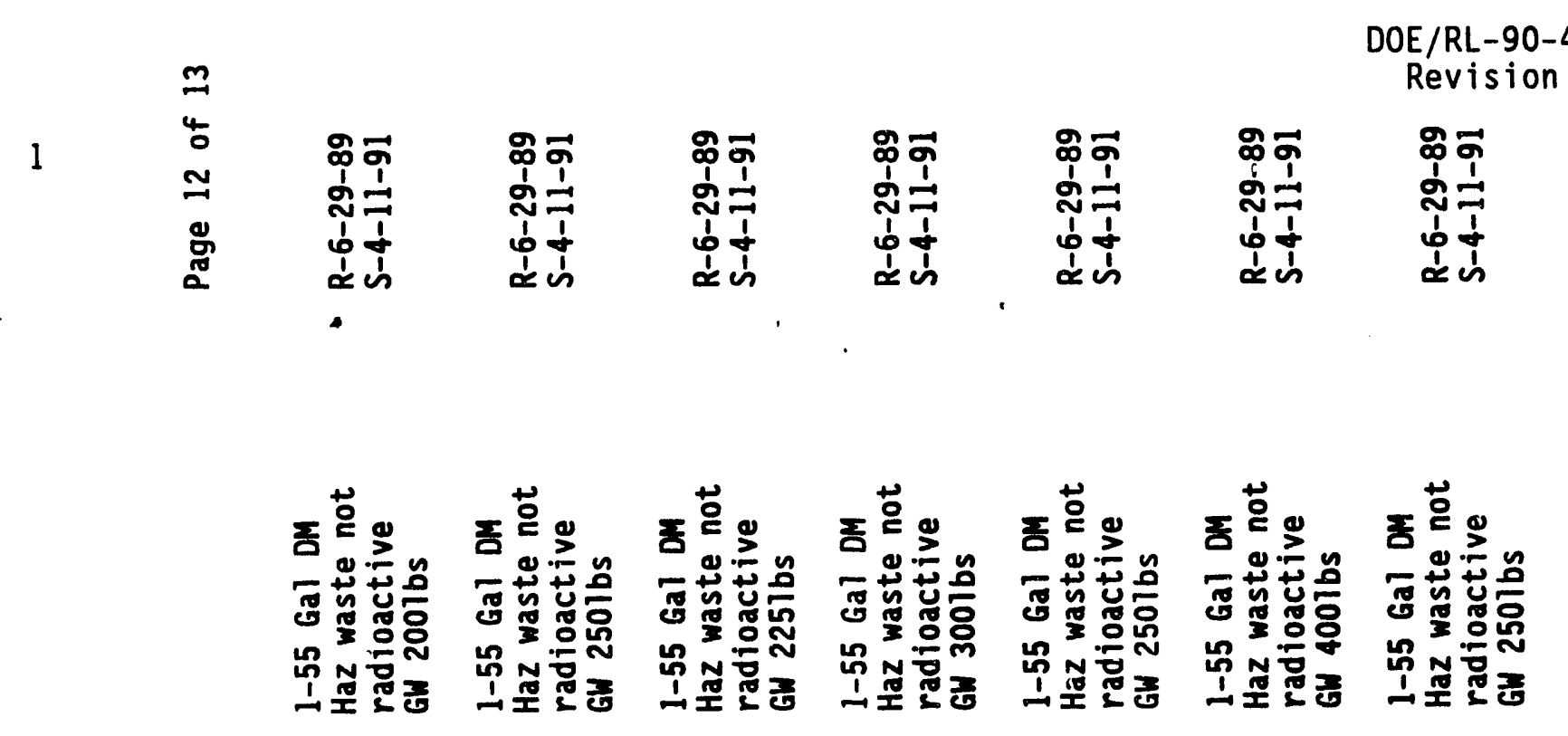

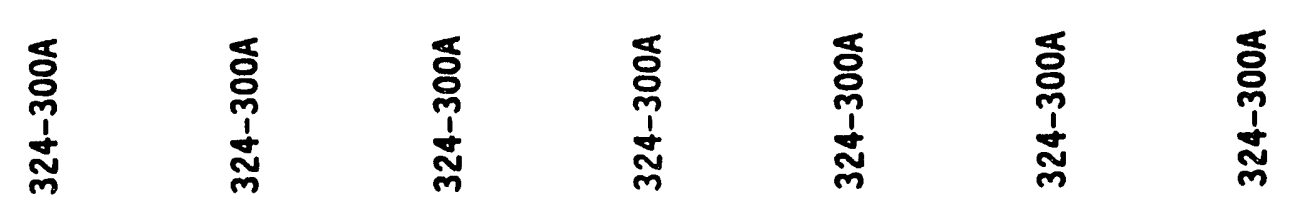

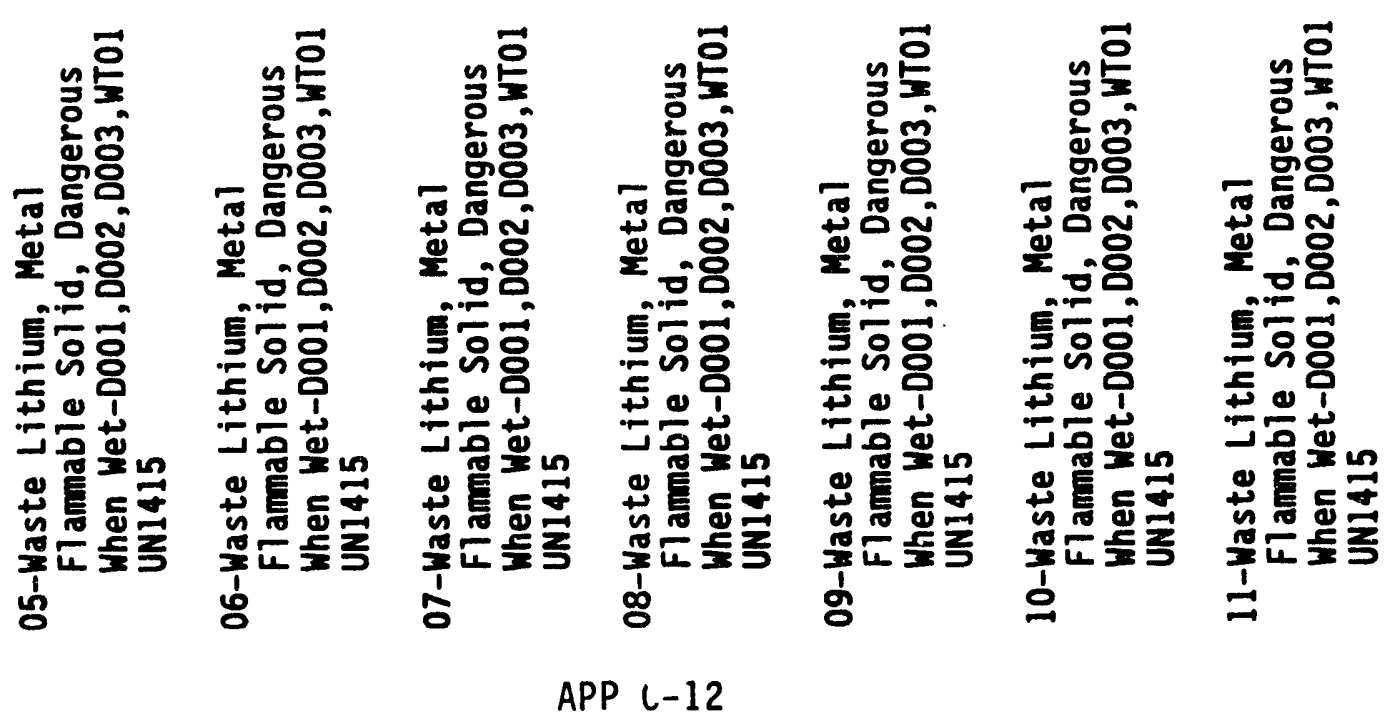


DOE/RL-90-49

$m$ Revision 0

4 o

m

总 d

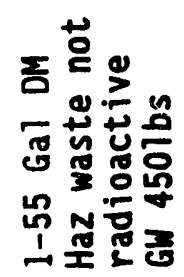

吉

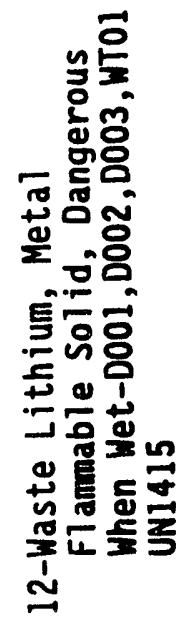


$\mathrm{DOE} / \mathrm{RL}-90-49$

Revision 0

1
2
3
4
5

This page intentionally left.blank. 
DOE/RL-90-49

Revision 0

APPENDIX D

SPILL REPORTS 
DOE/RL-90-49

Revision 0

1

2

3

4

5

6

7

8

9

10

\section{APPENDIX D}

\section{SPILL REPORTS}

This appendix contains the reports of two spills occurring within the 4843 AMSF. The associated Event Fact Sheets (EFS) are attached. Both spills resulted from leaks from waste containers and both spills were addressed and corrected promptly. 
DOE/RL-90-49

Revision 0

$\therefore$

$\ldots$

WHC

EYEMT FACT SHEET

Breached Radioactive Waste Sodium Container

2. zporting Org: 300 Area Waste Services

3. Jiv/Dept/Proj: Sol id Waste Management Defense Waste Management
4. No: SWM-90-004

5. Rev:

6. Event Date: 02/05/90 Event Time: 1430

7. Eyent Identification:

A) Location of Event: 4843 Building/400 Area

B) Plant/Facility Status: Kormal Surveillance Routine.

1. Alarm: Facility Type (False, 5. Radiological - Personnel

Fire, CAM, CAS, etc)

2. Regulatory Requirement (CERCLA, RCRA, WOOE, DOE-RL, DOE-HQ, etc)

3. Operating Requirements (OSR, CPS, Tech Spec, Procedure, Administrative, etc)

4. Release/Spread - Radloactive Contamination/Hazardous Material Contamination, Internal Deposition, Over Exposure, ete.

6. Industrial Safety, Personnel Injury, First Aid, ete.

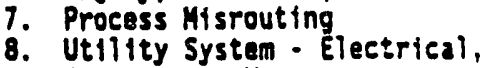
Steam, Air, Water

9. Hoisting/Lifting

C) Event Type: 4-Contaminated Sodfun Carbonate seed through weld seam of a DOT 7A container.

8. Apparent Cause(s) of Event:
[P] Design
[] Administrative Control
[ ] Personnel Error
(]) Procedure
[S] Material
[ ] Other:

9. Descriotion of Eyent: On February 5, 1990 at 1430 a small quant tey of sodium carbonate was discovered along a welded seam and underneath a DOT $7 \mathrm{~A}$ metal box containing radioactive waste sodium. A Plant Engineer, Nuclear Process Operator, and Health Physics Technician from the 340 Facility, cleaned up the material and covered the potential leak area. The material from the container reads 600 counts per minute.

10. Consequences of Event: The DOT 7A Metal container will need to be reevaluated with respect to the containers ability to provide containment. The release of radioactive contaminated material outside a surface contamination area.

$\therefore$

11. Actions Taken (A) or Planned (B):

Actions Taken:

A-1. The area was cleaned up and the potentially breached areas were taped.

Completed $2 / 5 / 90$ 
A-2. Temporary radioactive surface contamination area was established. Completed $2 / 5 / 90$

A-3. DOE-RL program monitor notified. Completed $2 / 5 / 90$

A-4. Notified Solid Waste Management. Completed 2/5/90

A-5. Notified Environmental Protection. Completed 2/5/90

A-6. Notified Nuclear Safety.

Completed 2/5/90

A-7. Implement daily inspection of the container by 300 Area Waste Services until the container is temporary repackaged and transfer by Advanced Reactor Division to a suttable location for further disposition.

Completed 2/6/90

A-8. Decontaminate and release temporary zone.

-
0
-
-
-
-
-
Compieted $2 / 6 / 90$ Action Planned:

8-1. Provide additional radiological containment for the $7 A$ box. Chemical and Waste Applications by $2 / 9 / 90$.

B-2. Develop and plan action for recovery. Chemical and Waste Applications by $2 / 28 / 90$.

12. Tentative Disposition:

13. Signatures:

$\frac{C \text { Originator: }}{{ }_{300}^{C} \text { Area Wean, Plant Engineer }}$

$\frac{02-06-50}{\text { Date: }}$

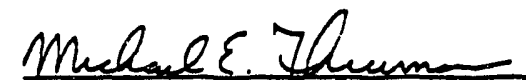

Approved By: M. E. Thurman, Manager

300 Area Haste Services

$\frac{2-6-90}{\text { 0ate: }}$
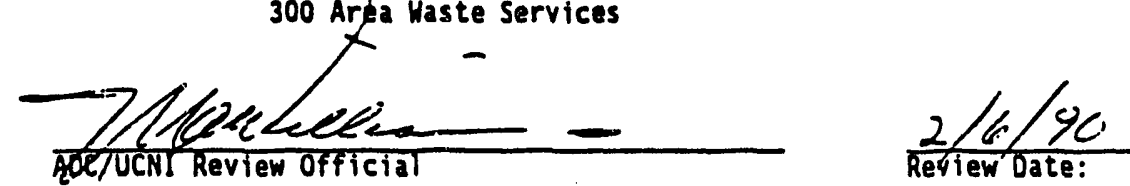
DOE/RL-90-49

Revision 0

1

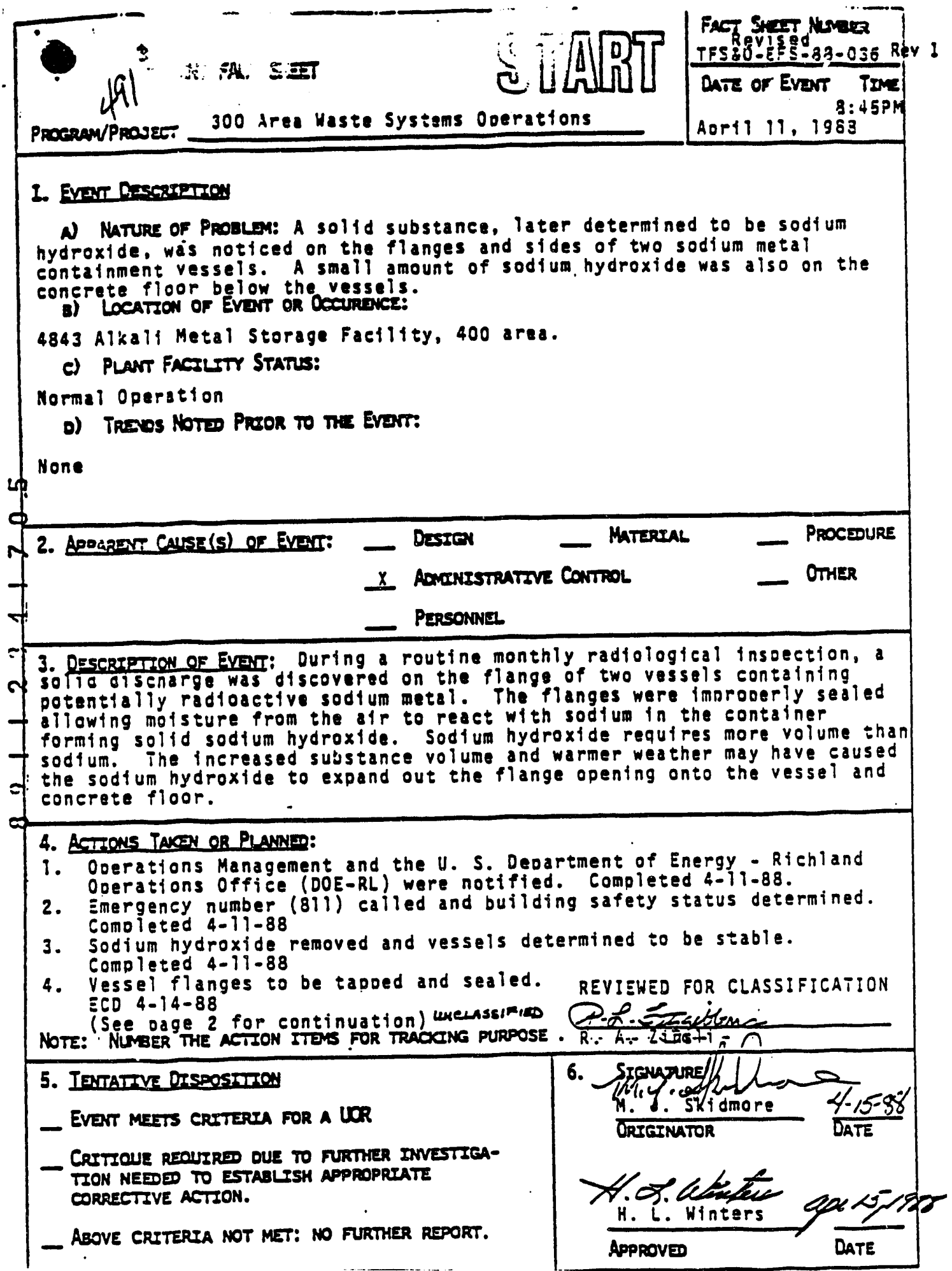


DOE/RL-90-49

Revision 0

\section{TF5:0-EF5-88-036 ReV ?}

Page 2

4. Actions Taken or planned:

5. Process Engineering investigation of vessels orfgin, shioping documentation, and storage and handiting procedures. ECD $5 / 27 / 88$

6. Westfinghouse Hanford Company Defense Waste Safety notfifed. Completed $4-11-88$

4. Revtsion of Acttons Taken or planned

Revised 4.4 Installed neoprene olug with a threaded stainless steel tube in each vessel fianges, after purging the vessels with argon, the tubing was capoed off.

$\infty$ Completed 4-12-88

N
7. Process Engineering investigating options for long term scorage disposition. ECD 5-27-88.

$\nabla$

$m$

N

$-$

$-$

c.

$\dot{0}$ 
DOE/RL-90-49

Revision 0

APPENDIX E

PHOTOGRAPHS

APP $E-i$ 
DOE/RL-90-49

Revision 0

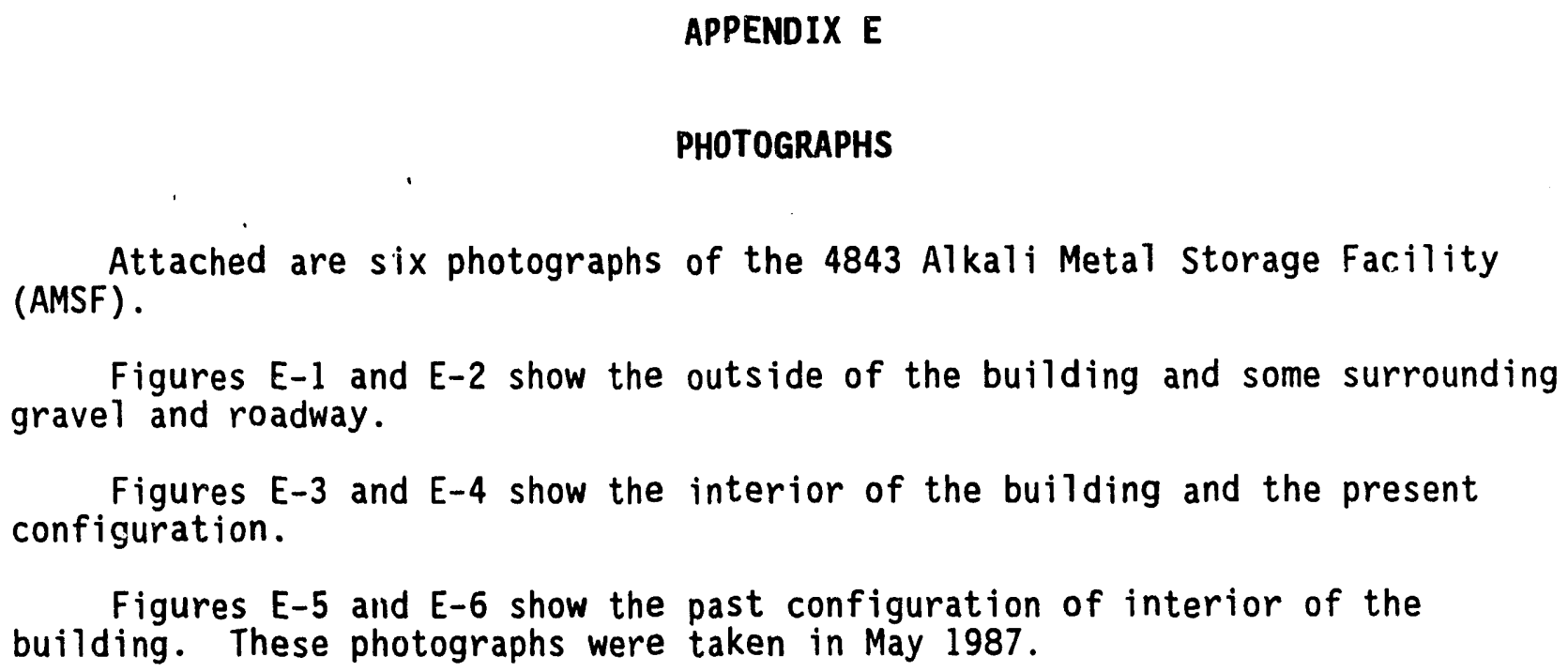

Figures E-1 and E-2 show the outside of the building and some surrounding gravel and roadway.

Figures E-3 and E-4 show the interior of the building and the present configuration.

Figures E-5 and E-6 show the past configuration of interior of the building. These photographs were taken in May 1987. 
DOE/RL-90-49

Revision 0

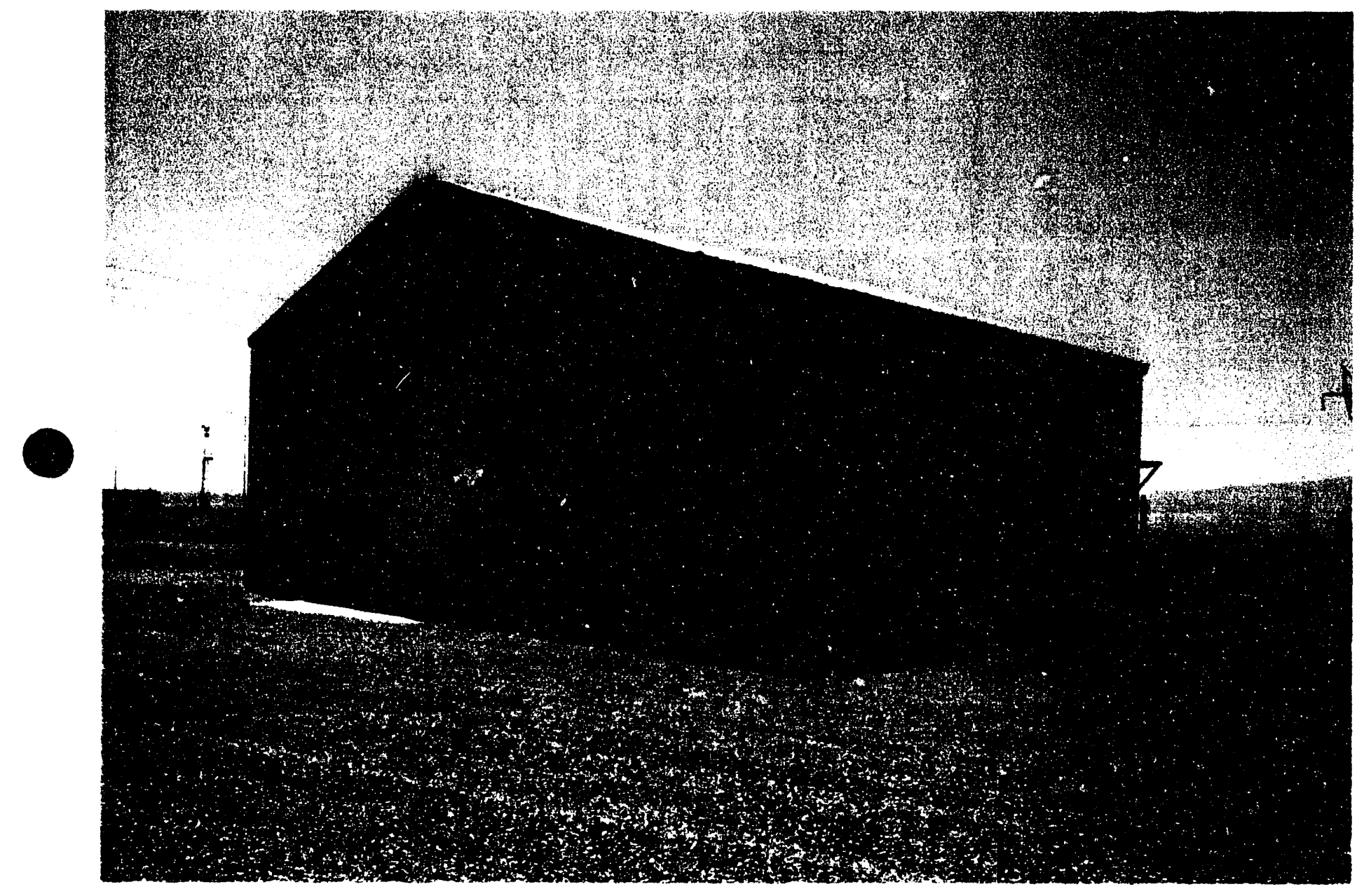

Figure E-1. The East End of the 4843 AMSF. Photograph taken December 1990. 
DOE/RL-90-49

Revision 0

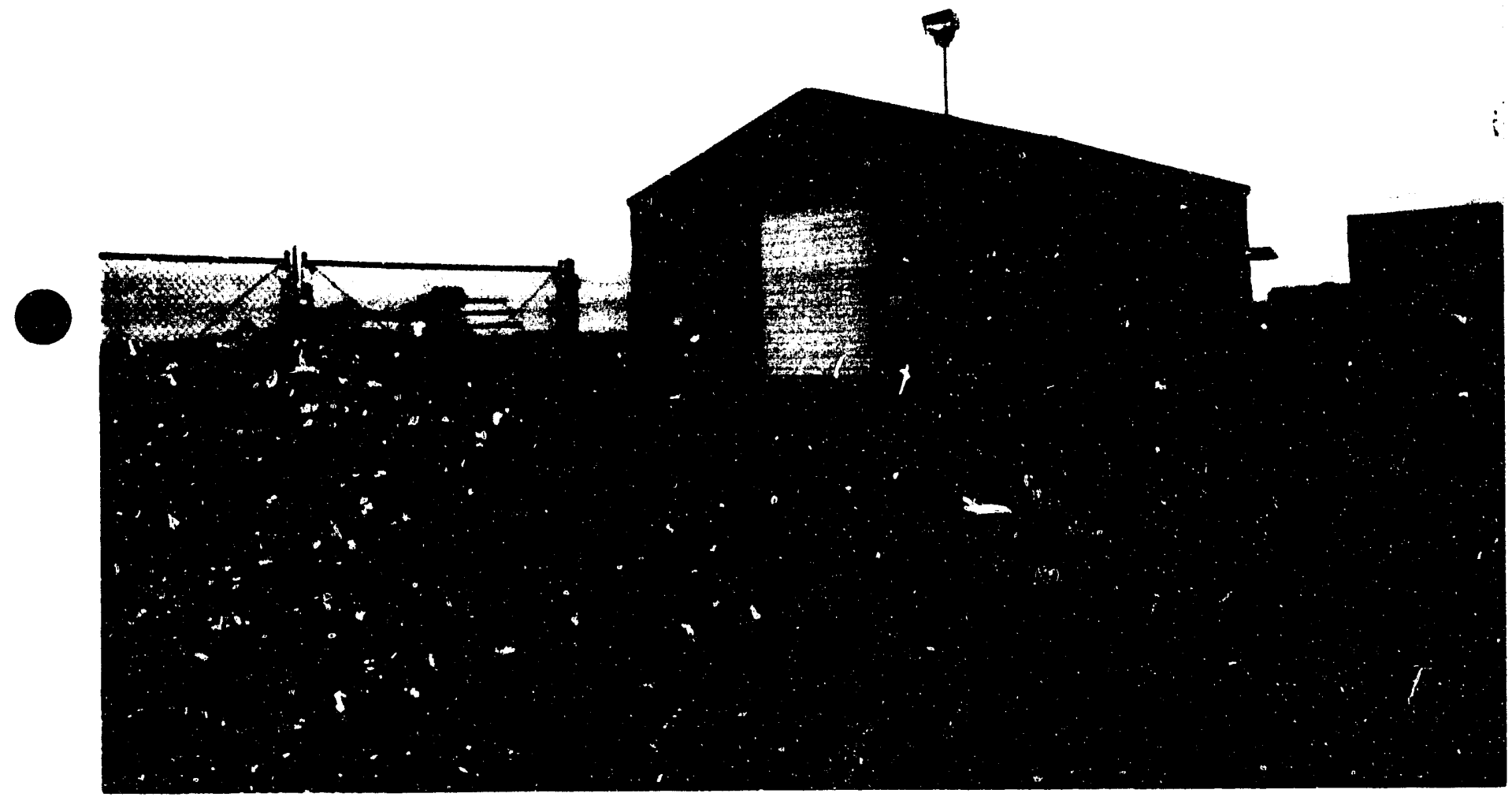

Figure E-?. The West End of the 4843 AMSF. The chain-link fence surrounds the 400 Area Laysown Area. Photograph taken December 1990. 
DOE/RL-90-49

Revision 0

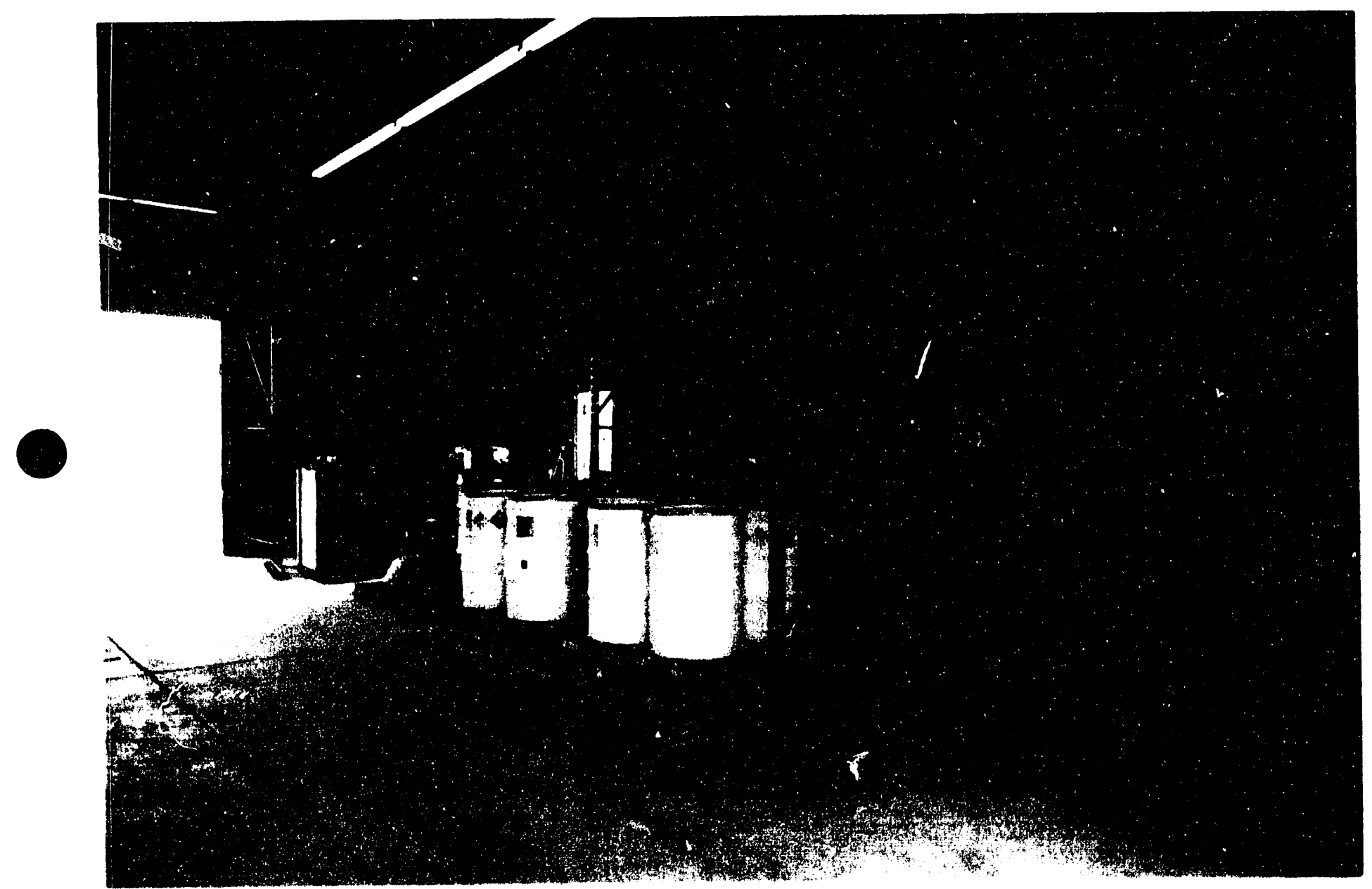

Figure E-3. Interior of the 4843 AMSF. Present configuration showing containers of dangerous waste.

Photograph taken December 1990. 
$\mathrm{DOE} / \mathrm{RL}-90-49$

Revision 0

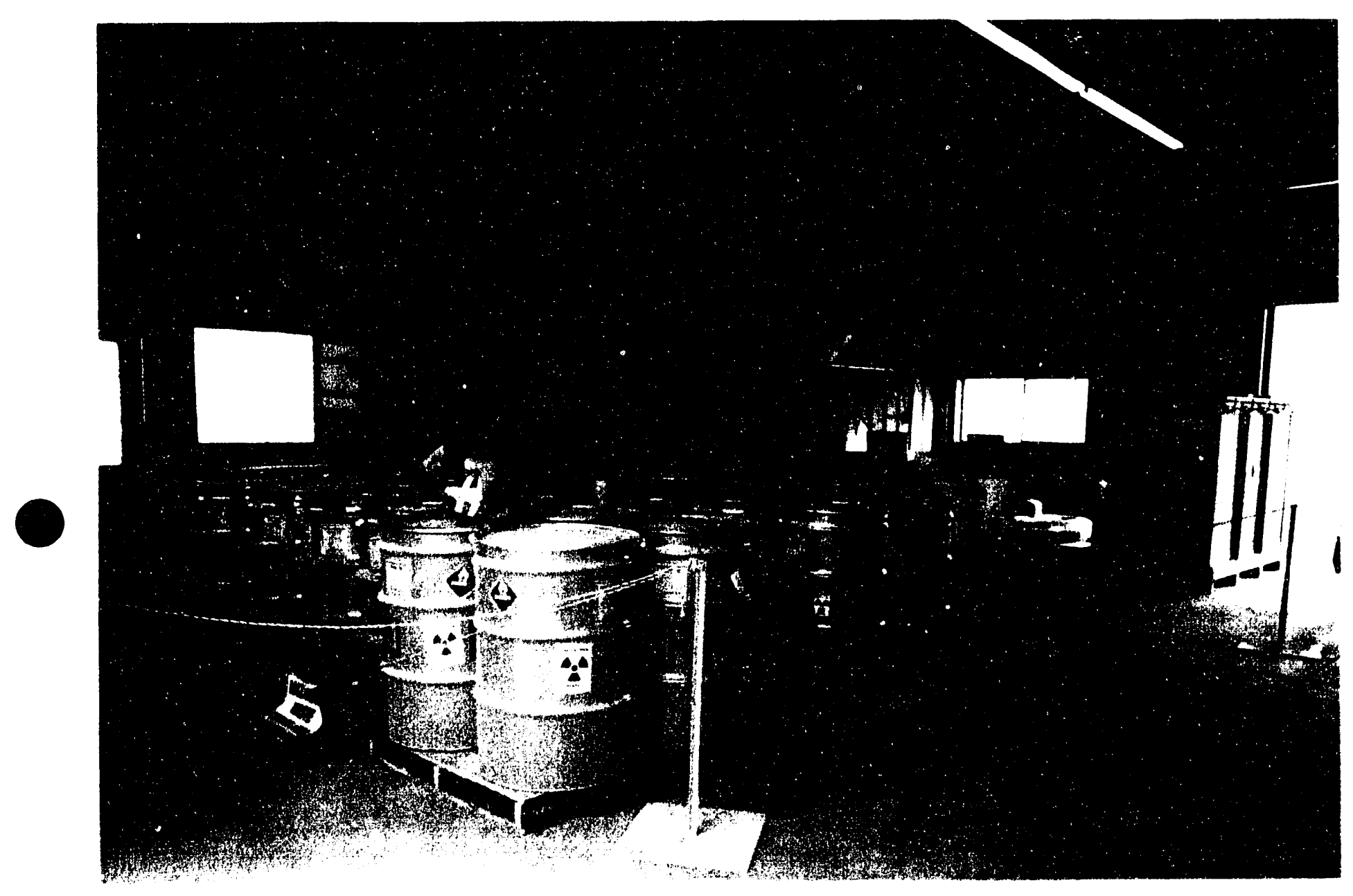

Figure E-4. Interior of the 4843 AMSF. Present configuration showing containers of mixed alkali metal waste. Photograph taken December 1990. 
DOE/RL-90-49

Revision 0

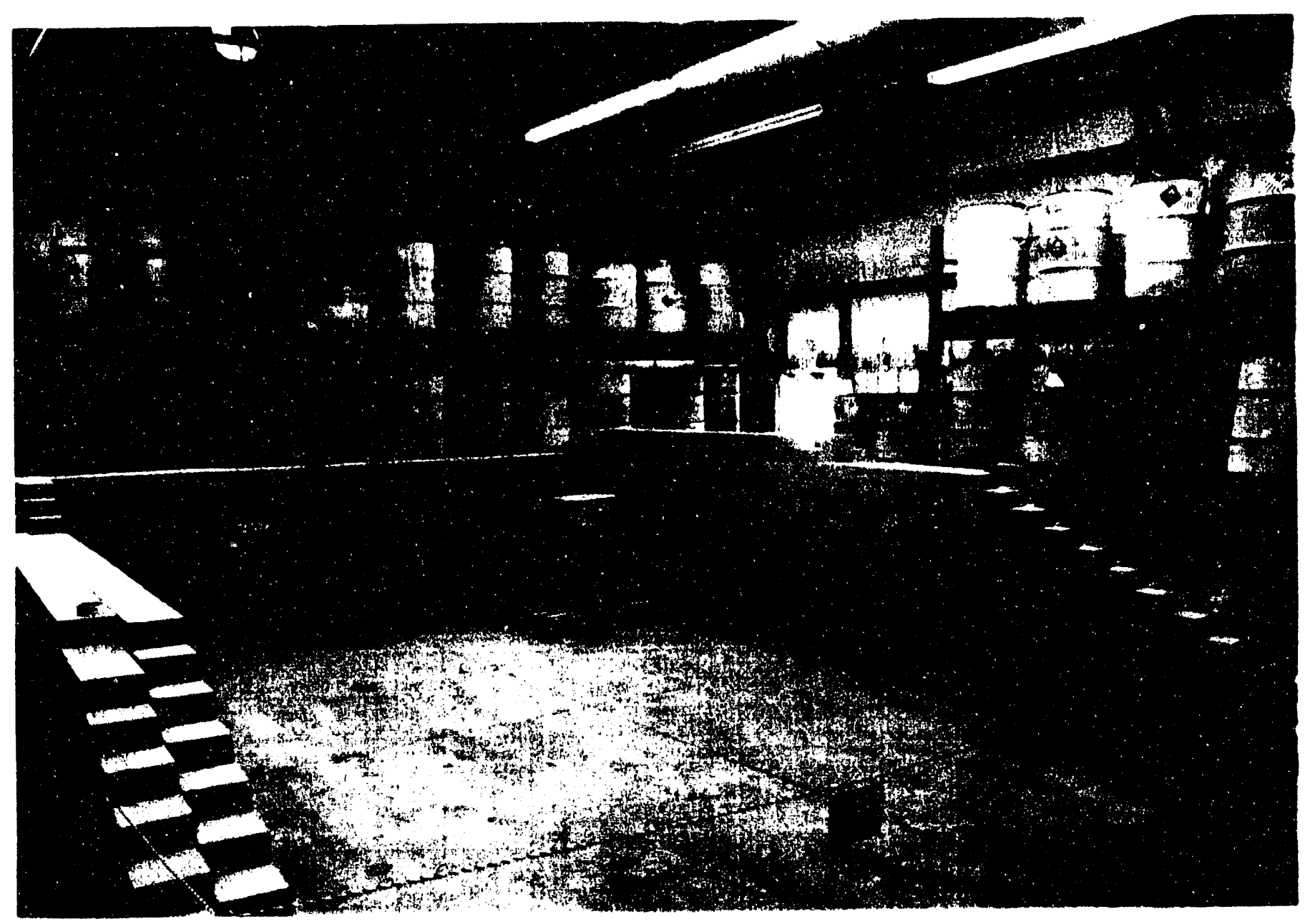

Figure E-5. Interior of the 4843 AMSF. Past configuration showing stacked nonwaste lithium metal containers and single container of

mixed alkali metal waste. Photograph taken May 1987 
DOE/RL-90-49

Revision 0

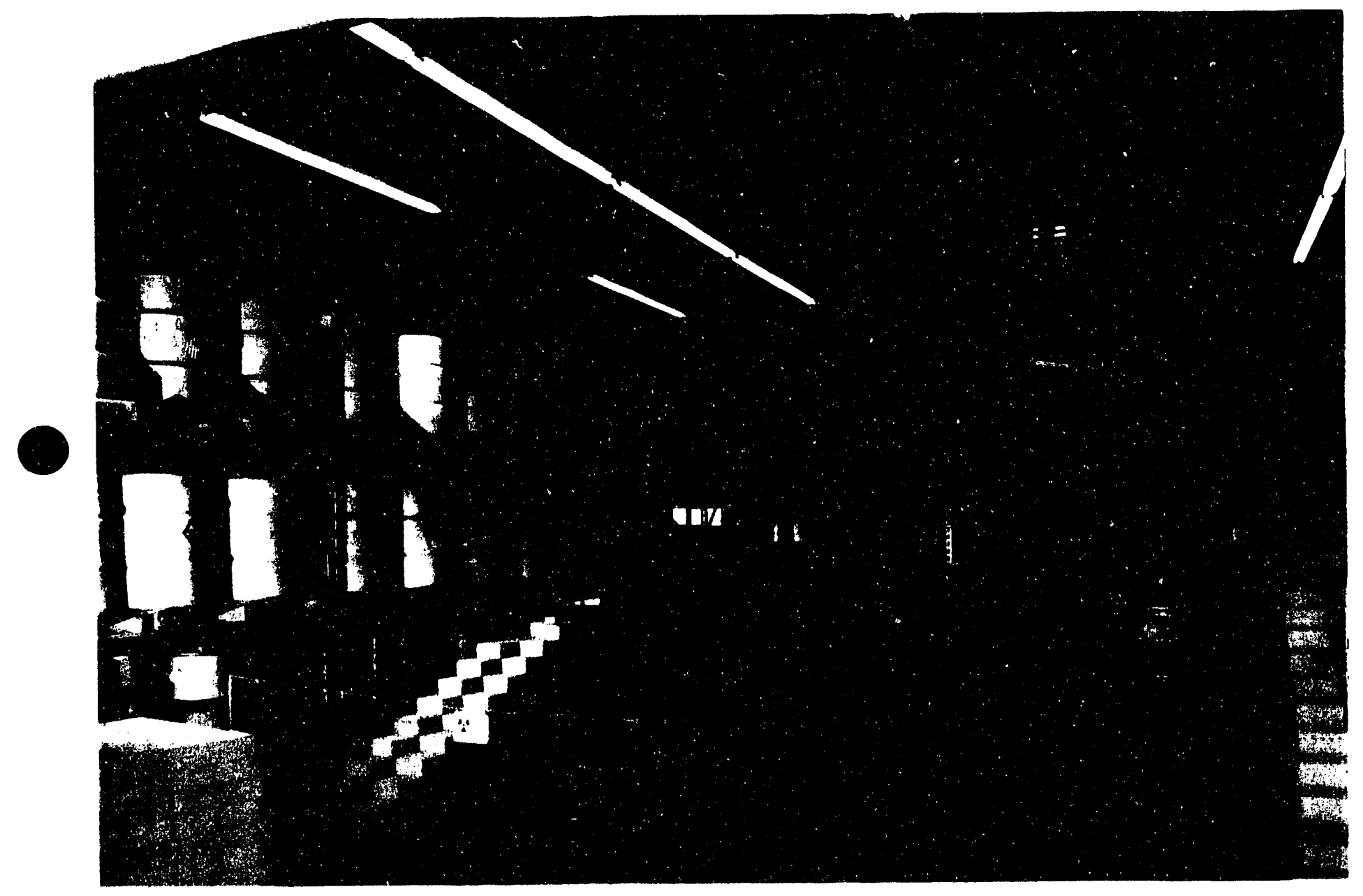

Figure E-6. Interior of the 4843 AMSF. Past configuration showing stacked nonwaste lithium metal containers and single container of mixed alkali metal waste. Photograph taken May 1987. 
DOE/RL-90-49

Revision 0

\section{APPENDIX $F$}

\section{PERSONNEL TRAINING}

APP $F-i$ 
DOE/RL-90-49

Revision 0

1
2
3
4
5

This page intentionally left blank. 
$1 \quad$ C.1

2 Title:

3 Description:

4 Target Audience:

5 Technique:

6 Evaluation:

7 Length:

8 Frequency:

9

10

11 Title:

12 Description:

\section{COMPANY-GENERAL RULES}

Generator Hazards Safety Training

Provides the dangerous material/waste worker with the fundamentals for safe use and disposal of dangerous materials.

Dangerous material and waste workers

Classroom

Written test

4 hours

24 months.

Hazardous Waste Worker Safety Training

Provides the dangerous waste worker with the fundamentals of safety when working with dangerous waste.

Note: This course fulfills training requirements of 29 CFR 1910.120 requiring dangerous waste training of workers at all treatment, storage, and/or disposal facilities regulated under RCRA.

14 Target Audience: Dangerous material and waste workers

15 Technique:

Classroom and on-the-job training

16 Evaluation:

Written test

17 Length:

24 hours

18 Frequency:

Not applicable.

19 
1 Title:

2 Description:

3

4 Target Audience: Dangerous material and waste workers

5 Technique:

6 Evaluation:

7 Length:

8 Frequency:

9

10

11 Title:

12 Description:

13

14 Target Audience:

15 Technique:

16 Evaluation:

17 Length:

18 Frequency:

training

On-the-job training

On-the-job training checklist

Average - 2 hours

12 months.
Hazardous Waste Worker Safety Training Refresher

Provides the dangerous waste worker with a refresher in the fundamentals of safety when working with dangerous waste.

Note: This course fulfills training requirements of 29 CFR 1910.120 requiring dangerous waste training of workers at all treatment, storage, and/or disposal facilities regulated under RCRA.

Classroom

Written test

8 hours

12 months.
Hazardous Material/Waste job-Specific Training

Provides job-specific dangerous material/waste information. Two checklists may be obtained from safety training to help the supervisor/manager through this session with each employee.

Note: Not a classroom presentation--supervisor conducts this exercise with each employee using the checklists.

Employees who complete generator hazards safety 
$1 \quad$ Title:

2 Description:
Scott SKA-PAK MSA PAPR

This class is designed to instruct employees in the proper use of the Scott "SKAPAK" for entry, exit, or work in conditions immediately dangerous to 1 ife and health, and to instruct employees to recognize and handle emergencies. This class also includes instructions in the use of MSA PAPR.

3 Target Audience: General, Safety, QA, OPS/OPRS, Management, Maintenance Engineering

4 Technique: Classroom

5 Evaluation: Practical exam

6 Length:

Approximately 2 hours

7 Frequency:

12 months.

8

9

10 Title:

11 Description:
Self-Contained Breathing Apparatus (SCBA) Annual Qual ification

Provides instructions in the proper use of a pressure-demand respirator in which breathing air is supplied from a cylinder carried on the user's back. The SCBA are typically used for emergency response situations in an atmosphere that is immediately dangerous to life or health.

12 Target Audience: General, Safety, OPS/OPRS, Maintenance

13 Technique:

Taught in a classroom using a slide projector and overhead projector

14 Evaluation: Written and practical test

15 Length: Approximately 4 hours

16 Frequency: 12 months. 
1 Title:

2 Description:
Radiation Safety Training

A practical dress/undress demonstration is also required. Instructs radiation workers in the fundamentals of radiation protection and the proper procedures for monitoring exposures (ALARA). Training includes knowledge of the acute and chronic effects of exposure to radiation risks associated with occupational radiation exposure, mode of exposure, protective measures, instrumentation, monitoring programs, contamination control, personnel decontamination, warning signs and alarms, and responsibilities of employees and managers.

3 Target Audience: Radiation workers as defined in WHC-CM-4-10

4 Technique:

Taught in a classroom using a white board, and appropriate audio/visual equipment

Written exam and practical dress/undress

Approximately 7 hours

24 months (retraining under Course Number 020003).

7 Frequency:

8

9

Title:

On-The-Job Training

11 Description:

On-the-job training under the supervision of an experienced person before full responsibilities may be assumed. In addition, all personnel on the hazardous waste site are required to have reviewed this Waste Sampling and Analysis Plan.

12 Target Audience: Nuclear Operators and Operations Management

13 Technique:

Classroom and on-the-job training

14 Evaluation:

Practical exercise and on-the-job training checklist

15 Length:

40 hours

16 Frequency:

12 months. 
1 Title:

2 Description:

3 Target Audience:

4 Technique:

5 Length:

6 Frequency:

7

8

9 Title:

10 Description:

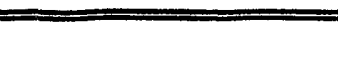

Cardiopulmonary Resuscitation (CPR)

Provide cardiopulmonary Resuscitation training to American Heart Association standards.

Hazardous Waste Worker

$\mathrm{Cl}$ assroom and active participation

4 hours

24 months (recertification)

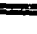

$-2=$

Noise Control (Noise-Hearing Conservation)

Provide employees with information conducive to hearing conservation. Supervisors and employees responsibility, exposure limits, hearing conservation requirements, protection devices, diagnosis of noise, induced hearing loss

11 Target audience: All employees exposed to an 8 hour time weighted average sound level of $85 \mathrm{dBA}$ or greater

12 Technique: Classroom

13 Evaluation: None

14 Length: Approximately 1 hour

15 Frequency: 12 months.

16

17 
DOE/RL-90-49

Revision 0

This page intentionally left blank. 
DOE/RL-90-49

Revision 0

\section{APPENDIX G}

QUALITY ASSURANCE PROJECT PLAN FOR SAMPLING AT

THE 4843 ALKALI METAL STORAGE FACILITY 
DOE/RL-90-49

Revision 0

$$
\begin{aligned}
& 1 \\
& 2 \\
& 3 \\
& 4 \\
& 5
\end{aligned}
$$

This page intentiona ${ }^{-}$: left blank. 
DOE/RL-90-49

Revision 0

\section{CONTENTS}

GLOSSARY

APP G-vii

1.0 PROJECT DESCRIPTION ................. APP G-1

1.1 PROJECT OBJECTIVE...... . . APP G-1

1.2 BACKGROUND INFORMATION .............. APP G-1

1.3 QUALITY ASSURANCE PROJECT PLAN APPLICABILITY AND

RELATIONSHIP TO THE WESTINGHOUSE HANFORD

COMPANY QUALITY ASSURANCE PROGRAM .......... APP G-1

1.4 SAMPLING AND TESTING ACTIVITIES . . . . . . . . . APP G-1

2.0 PROJECT ORGANIZATION AND RESPONSIBILITY . . . . . . . . APP G-2

2.1 PROJECT MANAGEMENT RESPONSIBILITIES ......... APP G-2

2.2 ANALYTICAL LABORATORIES .............. . . . . APP G-4

2.3 OTHER SUPPORT CONTRACTORS . . . . . . . . . . . . . . APP G-4

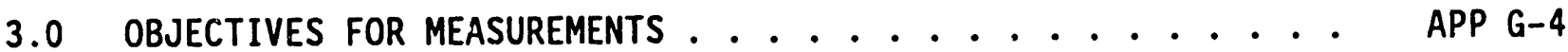

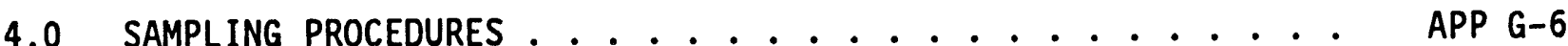

4.1 PROCEDURE APPROVALS AND CONTROL ......... . . APP G-6

4.1.1 Westinghouse Hanford Procedures . . . . . . . . . APP G-6

4.1.2 Participant Contractor/Subcontractor Procedures . APP G-7

4.2 SAMPLING AND INVESTIGATIVE PROCEDURES ........ APP G-7

4.3 PROCEDURE ADDITIONS AND CHANGES ........... APP G-9

5.0 SAMPLE CUSTODY ............................. APP G-9

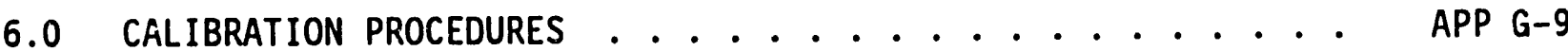

7.0 ANALYTICAL PROCEDURES ................ APP G-10

8.0 DATA REDUCTION, VALIDATION, AND REPORTING . ....... APP G-10

8.1 DATA REDUCTION AND DATA PACKAGE PREPARATION ...... APP G-10

8.2 VALIDATION ..... APP G-11

8.3 FINAL REVIEW AND RECORDS MANAGEMENT CONSIDERATIONS : . APP G-12

9.0 INTERNAL QUALITY CONTROL ............... APP G-12

10.0 PERFORMANCE AND SYSTEM AUDITS .............. APP G-13

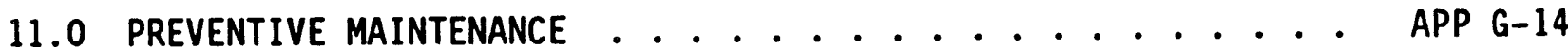

12.0 DATA ASSESSMENT PROCEDURES .............. APP G-14

13.0 CORRECTIVE ACTION ................................. APP G-14 
DOE/RL-90-49

Revision 0

1
2
3
4
5
6
7
8
9
10
11
12
13
14
15
16
17
18
19
20
21
22
23
24
25

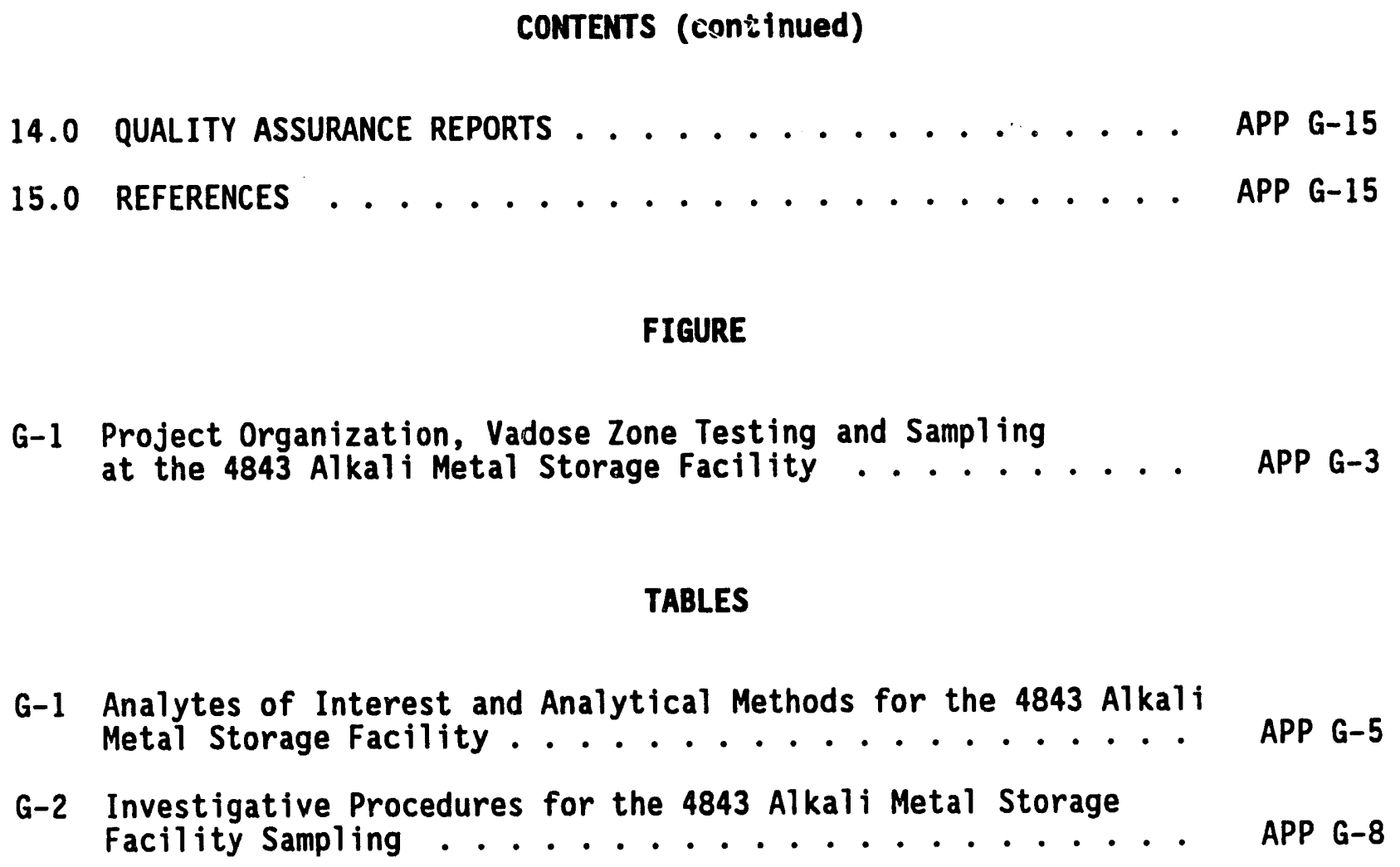


DOE/RL-90-49

Revision 0

\section{GLOSSARY}

Accuracy: For the purposes of closure activities, accuracy may be interpreted as the measure of the bias in a system. Sampling accuracy is normally assessed through the evaluation of matrix spiked samples and reference samples.

Audit: For the purposes of closure activities, audits are considered to be systematic checks to verify the quality of operation of one or more elements of the total measurement system. In this sense, audits may be of two types: (1) performance audits, in which quantitative data are independently obtained for comparison with data routinely obtained in a measurement system, or (2) system audits, involving a qualitative on-site evaluation of laboratories or other organizational elements of the measurement system for compliance with established quality assurance program and procedure requirements. For closure activities at the Hanford Site, performance audit requirements are fulfilled by periodic submittal of blind samples to the primary laboratory, or the analysis of split samples by an independent laboratory. System audit requirements are implemented through the use of standard surveillance procedures.

Blind Sample: A blind sample refers to any type of sample routed to the primary laboratory for purposes of auditing performance relative to a particular sample matrix and analytical method. Blind samples are not specifically identified as such to the laboratory; they may be made from traceable standards, or may consist of sample material spiked with a known concentration of a known compound. See the glossary entry for audit.

Comparability: For the purposes of closure activities, comparability is an expression of the relative confidence with which one data set may be compared with another.

Completeness: For the purposes of closure activities, completeness may be interpreted as a qualitative parameter expressing the percentage of measurements judged to be valid.

Deviation: For the purpose of closure activities, deviation refers to a planned departure from established criteria that may be required as a result of unforeseen field situations or that may be required to correct ambiguities in procedures that may arise in practical applications.

Equipment Blanks: Equipment blanks consist of pure deionized, distilled water washed through decontaminated sampling equipment and placed in containers identical to those used for actual field samples; they are used to verify the adequacy of sampling equipment decontamination procedures, and are collected once each day. 
Field Blanks: Fielc' blanks consist of pure deionized, distilled water, transferred to a sample container at the site and preserved with the reagent specified for the analytes of interest; they are used to check for possible contamination originating with the reagent or the sampling environment, and are collected once each day.

Field Duplicate Sample: Field duplicate samples are samples retrieved from the same sampling location using the same equipment and sampling technique, placed in separate identically prepared and preserved containers, and analyzed independently. Field duplicate samples are generally used to verify the repeatability or reproducibility of analytical data, and are normally analyzed with each analytical batch or every 20 samples, whichever is greater.

Matrix Spiked Samples: Matrix spiked samples are a type of laboratory quality control sample; they are prepared by splitting a sample received from the field into two homogenous aliquots (i.e., replicate samples), and adding a known quantity of a representative analyte of interest to one aliquot in order to calculate percentage of recovery.

Nonconformance: A nonconformance is a deficiency in characteristic, documentation, or procedure that renders the quality of material, equipment, services, or activities unacceptable or indeterminate. When the deficiency is of a minor nature, does not effect a permanent or significant change in quality if it is not corrected, and can be brought into conformance with immediate corrective action, it shall not be categorized as a nonconformance. However, if the nature of the condition is such that it cannot be immediately and satisfactorily corrected, it shall be documented in compliance with approved procedures and brought to the attention of management for disposition and appropriate corrective action.

Precision: Precision is a measure of the repeatability or reproducibility of specific measurements under a given set of conditions. Specifically, it is a quantitative measure of the variability of a group of measurements compared to their average value. Precision is normally expressed in terms of standard deviation, but may also be expressed as the coefficient of variation (i.e., relative standard deviation) and range (i.e., maximum value minus minimum value). Precision is assessed by means of duplicate/replicate sample analysis.

Quality Assurance: For the purposes of closure activities, quality assurance (QA) refers to the total integrated quality planning, quality control, quality assessment, and corrective action activities that collectively ensure that the data from monitoring and analysis meets a 11 end user requirements and/or the intended end use of the data.

Quality Assurance Project Plan: The quality assurance project plan (QAPP) is an orderly assembly of management policies, project objectives, methods, and procedures that defines how data of known quality will be produced for a particular project or investigation. 
1 Quality Control: For the purposes of closure activities, quality control (QC)

2 refers to the routine application of procedures and defined methods to the performance of sampling, measurement, and analytical processes.

Reference Samples: Reference samples are a type of laboratory quality control sample prepared from an independent, traceable standard at a concentration other than that used for analytical equipment calibration, but within the calibration range. Such reference samples are required for every analytical batch or every 20 samples, whichever is greater.

Replicate Sample: Replicate samples are two aliquots removed from the same sample container in the laboratory and analyzed independently.

Representativeness: For the purposes of closure activities, representativeness may be interpreted as the degree to which data accurately and precisely represent a characteristic of a population parameter, variations at a sampling point, or an environmental condition. Representativeness is a qualitative parameter which is most concerned with the proper design of a sampling program.

Split Sample: A split sample is produced through homogenizing a field sample and separating the sample material into two equal aliquots. Field split samples are usually routed to separate laboratories for independent analysis, generally for purposes of auditing the performance of the primary laboratory relative to a particular sample matrix and analytical method. See the glossary entry for 'audit'. In the laboratory, samples are generally split to create matrix spiked samples; see the glossary entry for matrix spiked samples.

Trip Blanks: Trip blanks are a type of field quality control sample, consisting of pure deionized distilled water in a clean, sealed sample container, accompanying each batch of containers shipped to the sampling site and returned unopened to the laboratory. Trip blanks are used to identify any possible contamination originating from container preparation methods, shipment, handling, storage, or site conditions.

Validation: For the purposes of closure activities, validation refers to a systematic process of reviewing a body of data against a set of criteria to provide assurance that the data are acceptable for their intended use. Validation methods may include review of verification activities, editing, screening, cross-checking, or technical review.

Verification: For the purposes of closure activities, verification refers to the process of determining whether procedures, processes, data, or documentation conform to specified requirements. Verification activities may include inspections, audits, surveillances, or technical review. 
DOE/RL-90-49

Revision 0

This page intentionally left blank. 
DOE/RL-90-49

Revision 0

\subsection{PROJECT DESCRIPTION}

\subsection{PROJECT OBJECTIVE}

The primary purpose of these investigations at the 4843 Alkali Metal Storage Facility (4843 AMSF) is to ensure that performance standards for the closure of the 4843 AMSF are satisfied.

\subsection{BACKGROUND INFORMATION}

The location of the 4843 AMSF and general background information are provided in Chapter 1.0 of the 4843 AMSF closure plan.

\subsection{QUALITY ASSURANCE PROJECT PLAN APPLICABILITY AND RELATIONSHIP TO THE WESTINGHOUSE HANFORD COMPANY QUALITY ASSURANCE PROGRAM}

This Quality Assurance Project Plan (QAPP) applies specifically to the field activities and laboratory analyses performed as part of closure activities for the 4843 AMSF at the Hanford Site. It is designed to be implemented in conjunction with the specific requirements of the 4843 AMSF closure plan. The QAPP is prepared in compliance with the Environmental Engineering, Technology, and Permitting Function Quality Assurance Program Plan (WHC 1990). This plan describes the means selected to implement the overal1 QA program requirements defined by the Westinghouse Hanford Company Quality Assurance Manual (WHC-CM-4-2) (WHC 1989a), as applicable to environmental investigations, while accommodating the specific requirements for project plan format and content agreed upon in the Hanford Federal Faciiity Agreement and Consent Order (Ecology et al. 1990). The program plan contains a matrix of procedural resources from WHC-CM-4-2 and from the Westirighouse Hanford Environmental Investigations and Site Characterization Manual (WHC-CM-7-7) (WHC 1989b) that have been drawn upon to support this QAPP. This QAPP is subject to mandatory review and revision before use on subsequent phases of the investigation. Distribution and revision control of this plan shall be in compliance with procedures QR 6.0, "Document Control" and QI 6.1, "Quality Assurance Document Control," all from WHC-CM-4-2 (WHC 1989a). All plans and procedures referenced in the QAPP are available for regulatory review on request by the direction of the Technical Lead.

\subsection{SAMPLING AND TESTING ACTIVITIES}

Field sampling and testing activities will include wipe samples and concrete samples. A complete description of all test activities is provided in Chapter 7.0 of the 4843 AMSF closure plan. 
DOE/RL-90-49

Revision 0

\subsection{PROJECT ORGANIZATION AND RESPONSIBILITY}

\subsection{PROJECT MANAGEMENT RESPONSIBILITIES}

The Environmental Engineering, Geotechnology, and Permitting Function of Westinghouse Hanford has primary responsibilities for conducting this investigation. An organizational chart is included as Figure G-1. Responsibilities of key test personnel and organizations are described as follows.

- Closure Plan Lead (Regulatory Permitting Group). The Closure Plan Lead is responsible for overall project organization and interface with the regulatory agencies and the U.S. Department of EnergyRichland Operations office (DOE-RL).

- Technical Lead. The Technical Lead will be responsible for the overall direction of sampling and testing activities; responsibilities include the planning and authorization of all work and management of any subcontracted activities, as well as the overall technical schedule, and budgetary performance.

- Quality Assurance Officer. The Quality Assurance Officer is responsible for coordination and/or oversight of performance to the QAPP requirements by means of internal auditing and surveillance techniques. The Quality Coordinator retains the necessary organizational independence and authority to identify conditions adverse to quality and to inform the Technical Lead of needed corrective action.

- Health and Safety Officer (Environmental Division/Environmental Field Services). The Health and Safety Officer is responsible for determining potential health and safety hazards from radioactive, volatile, and/or toxic compounds during sample handling and sampling decontamination activities and has the responsibility and authority to halt field activities that cause unacceptable health and safety hazards.

- Field Team Leader. The Field Team Leader is responsible for onsite direction of sampling technicians in compliance with the requirements of the 4843 AMSF closure plan, this QAPP, and all implementing Environmental Investigation Instructions (EII).

- Officer of Sample Management (OSM). The Westinghouse Hanford OSM is responsible for coordinating sample shipments between the field team and the analytical laboratory, resolution of any chain-of-custody issues, and validation of all analytical data as discussed in Section 8.0. 


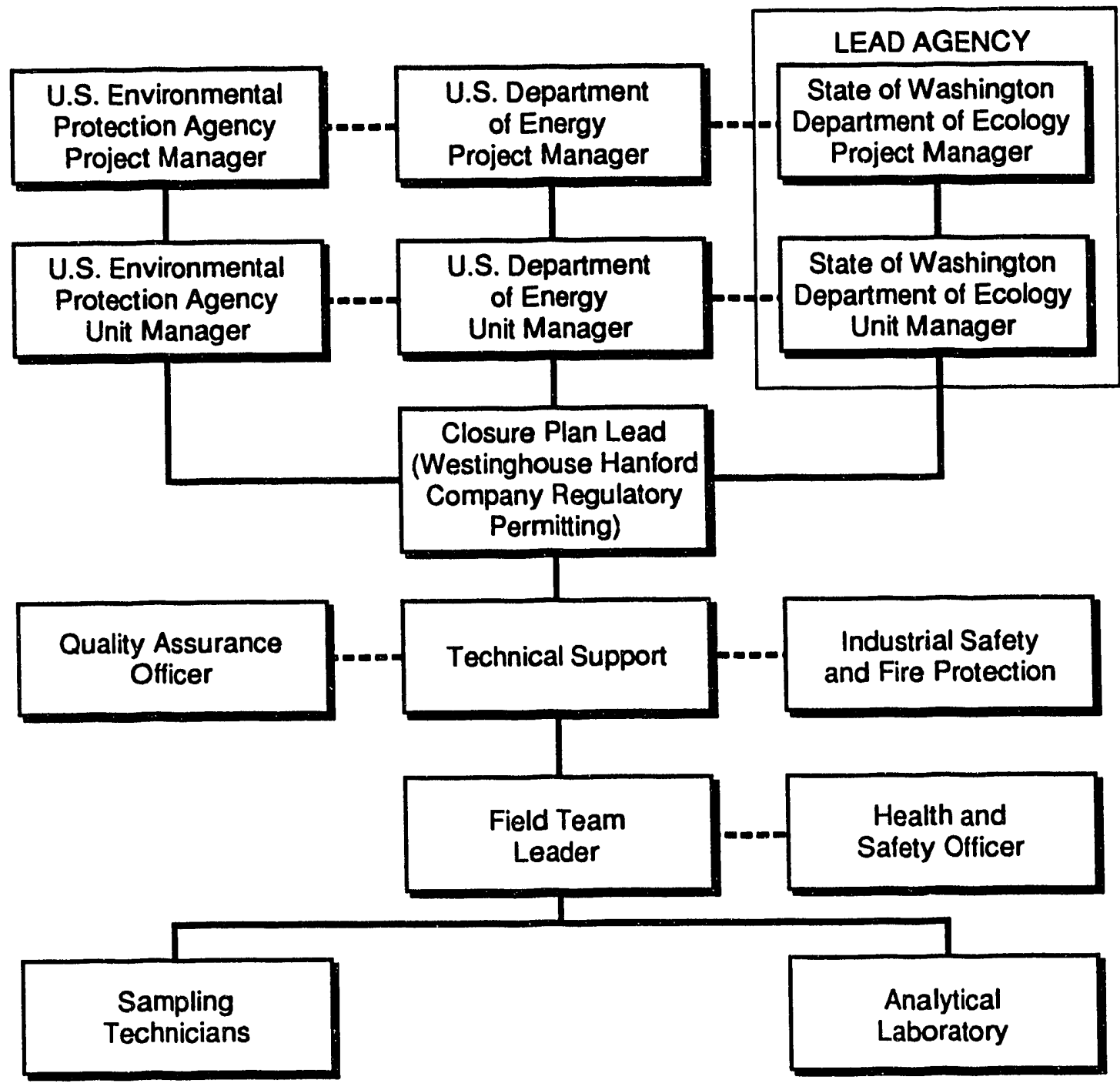

H9102002.2 
DOE/RL-90-49

Revision 0

\subsection{ANALYTICAL LABORATORIES}

Wipe and concrete samples will be routed to an approved Westinghouse Hanford participant contractor or subcontractor laboratory, who shall be responsible for performing the analyses identified in this plan in compliance with work orders, or contractual requirements and Westinghouse Hanford approved procedures (Section 4.1.2). At the Technical Lead's direction, services of alternate qualified laboratories may be procured for the performance of split sample analyses for performance audit purposes. If such an option is selected, the $Q A$ plan and applicable analytical procedures from the alternate laboratory shall also be approved by Westinghouse Hanford before their use in compliance with Section 4.1.2 requirements. All analytical laboratory work shall be subject to the surveillance controls invoked by QI 7.3, "Source Surveillance and Inspection" (WHC 1989a).

\subsection{OTHER SUPPORT CONTRACTORS}

Other support contractors may be assigned project responsibilities at the direction of the Technical Lead. Such services shall be in compliance with standard Westinghouse Hanford procurement procedure requirements as discussed in Section 4.1.2. All work shall be performed in compliance with Westinghouse Hanford approved quality assurance (QA) plans and/or procedures, subject to the controls of QI 7.3, "Source Surveillance and Inspection" (WHC 1989a).

\subsection{OBJECTIVES FOR MEASUREMENTS}

This investigation assesses the existence and nature of contamination within the 4843 AMSF. This assessment will focus on the physical and chemical properties of the interior of the 4843 AMSF.

As noted in Section 4.6 of Data Quality Objectives for Remedial Response Activities: Volume I, Development Process (EPA 1987), universal goals for precision, accuracy, representativeness, completeness, and comparability cannot be practically established at the outset of an investigation. However, data are available from previously negotiated analytical contracts for Hanford Site investigations, the Data Quality Objectives guidance document cited previously (EPA 1987), and typical capabilities currently expected for laboratories involved in environmental analyses, that may be used as minimum guidelines for the selection of analytical methods appropriate for this investigation. Table G-1 provides preliminary target values for detection limits, precision, and accuracy that are intended for use in initial procurement negotiations with the analytical laboratory. After individual laboratory statements of work are negotiated, and procedures are developed and approved (as noted in Section 4.1, Table G-2), this section shall be revised to reference approved detection limit, precision, and accuracy criteria as project requirements. 
DOE/RL-90-49

Revision 0

Table G-1. Analytes of Interest and Analytical Methods for the 4843 Alkali Metal Storage Facility Sampling.

\begin{tabular}{llllll}
\hline $\begin{array}{c}\text { Analytical } \\
\text { category }\end{array}$ & $\begin{array}{c}\text { Analyte } \\
\text { interest }\end{array}$ & $\begin{array}{c}\text { Standard } \\
\text { reference } \\
\text { method }\end{array}$ & $\begin{array}{c}\text { Minimum } \\
\text { detection } \\
\text { limit }^{c}\end{array}$ & Precision & Accuracy \\
\hline Inorganics & Sodium & $6010^{\circ}$ & $29 \mu \mathrm{g} / \mathrm{L}$ & $\pm 25 \% \mathrm{RPD}$ & $\pm 25 \%$ \\
& Lithium & $6010^{\circ}$ & $5 \mu \mathrm{g} / \mathrm{L}$ & $\pm 25 \%$
\end{tabular}

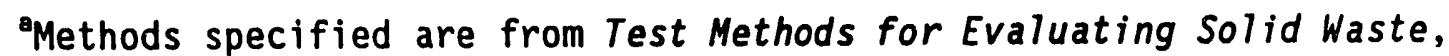
(SW-846), EPA 1986.

Analytical methods shall be in compliance with approved Westinghouse Hanford or Westinghouse Hanford-approved participant contractor or subcontractor procedures. All procedures shall be reviewed and approved in compliance with requirements specified in the Westinghouse Hanford QA Program Plan for Comprehensive Environmental Response, Compensation and Liability Act of 1980 (CERCLA) remedial investigation/feasibility study (RI/FS) activities.

cInductively coupled plasma/atomic emission spectroscopy (ICP-AES) analysis performed for the elements listed. No results shown for concentrations below detection limit.

Minimum requirements for precision and accuracy will be methodspecific, and shall be negotiated and established in the procedure review and approval process. Target values are indicated where appropriate; precision is expressed in terms of relative percent different (RPD) and accuracy as percentage recovery.

eAnalyses shall be performed by an approved participant contractor or subcontractor laboratory. 
Goals for data representativeness are addressed qualitatively by the specification of sampling locations and intervals within Chapter 7.0 of the 4843 AMSF closure plan. Objectives for completeness for this investigation shall require that contractually or procedurally established requirements for precision and accuracy be met for at least 90 percent of the total number of requested determinations. Failure to meet these criteria shall be documented in data summary reports as described in Section 8.1 , and shall be considered in the validation process discussed in Section 8.2. Corrective action measures shall be initiated by the Technical Lead as appropriate, as noted in Section 13.0. Approved analytical procedures shall require the use of reporting techniques and units consistent with the EPA reference methods listed in Table G-1 to facilitate the comparability of data sets in terms of precision and accuracy.

\subsection{SAMPLING PROCEDURES}

\subsection{PROCEDURE APPROVALS AND CONTROL}

\subsubsection{Westinghouse Hanford Procedures}

The Westinghouse Hanford procedures that will be used to support the closure plan have been selected from the Quality Assurance Program Index (QAPI) included in the Environmental Engineering, Technology, and Permitting Function Quality Assurance Program Plan (WHC 1990). Selected procedures include Environmental Investigations Instructions from the Environmental Investigations and Site Characterization Manual (WHC 1989b), and quality requirements (QR) and quality instructions (QI), from the Westinghouse Hanford Quality Assurance Manual (WHC 1989a). Procedure approva1, revision, and distribution control requirements applicable to EII are addressed in EII 1.2, "Preparation and Revision of Environmental Investigation Instructions" (WHC 1989b); requirements applicable to $Q I$ and $Q R$ are addressed in $Q R$ 5.0, "Instructions, Procedures, and Drawings"; QI 5.1, "Preparation of Quality Assurance Documents"; QR 6.0, "Document Control"; and QI 6.1 "Quality Assurance Document Control" (WHC 1989a). Other procedures applicable to the preparation, review, approval, and revision of OSM and other Hanford Site analytical laboratories organization procedures shall be as defined in the Environmental Engineering, Technology, and Permitting Function Quality Assurance Program Plan (WHC 1990) under Criteria 5.00 and 6.00. A11 procedures are available for regulatory review on request, at the direction of the Technical Lead. 
DOE/RL-90-49

Revision 0

\subsubsection{Participant Contractor/Subcontractor Procedures}

As noted in Section 2.1, participant contractor and/or subcontractor services may be procured at the direction of the Technical Lead. All such procurements shall be subject to the applicable requirements of QR.4.0, "Procurement Document Control"; QI 4.1, "Procurement Document Control"; QI 4.2, "External Services Control"; QR 7.0, "Control of Purchased Items and Services"; QI 7.1, "Procurement Planning and Control"; and/or QI 7.2, "Supplier Evaluation" (WHC 1989a). Whenever such services require procedural controls, requirements for use of Westinghouse Hanford procedures, or submittal of contractor procedures for Westinghouse Hanford review and approval before use, they shall be included in the procurement document or work order, as applicable. In addition to the submittal of analytical procedures, analytical laboratories shall be required to submit the current version of their internal QA Program plans.

All analytical laboratory $\mathrm{plans}$ and procedures shall be reviewed and approved before use by qualified personnel from the OSM, Westinghouse Hanford analytical laboratories organizations, or other qualified personnel, as directed by the Technical Lead. All participant contractor or subcontractor procedures, plans and/or manuals shall be retained as project quality records in compliance with EII 1.6, "Records Management" (WHC 1989b); QR 17.0, "Qual ity Assurance Records"; and QI 17.1, "Quality Assurance Records Control" (WHC 1989a). The DOE shall submit laboratory QA/QC plans to EPA and Ecology for review before the use of the laboratory. All such documents are available for regulatory review on request, at the direction of the Westinghouse Hanford Technical Lead.

\subsection{SAMPLING AND INVESTIGATIVE PROCEDURES}

All sampling activities shall be performed in accordance with EII 5.2 (WHC 1989b); and Chapter 7.0 of the 4843 AMSF closure plan. However, should sampling procedures prove to be inadequate the field team leader must document any procedural changes.

Samples shall routinely be routed to offsite analytical laboratories for chemical analyses; additional EII and documented field procedures that have been selected to support the test activity are identified in Table G-2. Sample identification requirements and container type, preparation, and preservation requirements shall be as specified in EII 5.2. All sampling equipment decontamination shall be in compliance with EII 5.5, "Decontamination of Equipment for RCRA/CERCLA Sampling" (WHC 1989b). Other procedures required to support activities and data interpretation shall be developed as modifications to EII 11.2 , as contractor procedures, or may be incorporated as addenda to this QAPP as necessary to support the detailed requirements of the 4843 AMSF closure plan. 
DOE/RL-90-49

Revision 0

1

2

3

4

5

6

7

8

9

10

11

12

13

14

15

16

17

Table G-2. Investigative Procedures for the 4843 Alkali Metal Storage Facility Sampling.

\begin{tabular}{lccc}
\hline Procedure & Title $^{a}$ & Wipe & Concrete \\
& Sampling & Sampling
\end{tabular}

EII 1.2 Preparation and Revision of Environmental $X$ Investigation Instructions

$\begin{array}{cl}\text { EII } 1.4 & \text { Devidtion from Environmental } \\ \text { Investigation Instructions }\end{array}$

\section{EII 1.5 Field Logbooks}

EII 1.6 Records Management

EII 1.7 Incioctrination, Training and Qualification
EII 2.1 Preparation of Hazardous Waste operation Permits

EII $2.3 \quad$ Administration of Radiation Surveys to
Support Environmental Characterization work on the Haríu.u Site

1 EII $3.1 \quad$ User Calibration of Health and Safety

Chain of custody

EII 5.1
EII 5.5 Decontamination of Equipment for RCRA/CERCLA Sampling
EII 5.10
Sample Identification and Entry into the HEIS Database
EII 5.11 Sample Packaging and Shipping

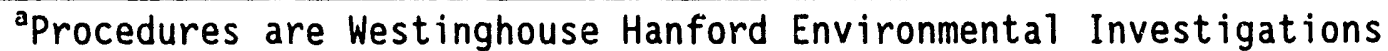 instructions (EIIs) selected from the latest approved version of WHC-CM-7-7, Environmental Investigations and Site Characterization Manual (WHC 1989b). $\begin{aligned} \text { CERCLA }= & \text { Comprehensive Environmental Response, Compensation, and Liability } \\ \text { Act of } 1980 & \text {. }\end{aligned}$
HEIS = Hanford Environmental Information System
$M \& T E=$ measure and test equipment
RCRA = Resource Conservation and Recovery Act of 1976.


$\mathrm{DOE} / \mathrm{RL}-90-49$

Revision 0

\subsection{PROCEDURE ADDITIONS AND CHANGES}

Additional EII or EII updates that may be required as a consequence of the 4843 AMSF closure $p l a n$ requirements shall be developed in compliance with EII 1.2, "Preparation and Revision of Environmental Investigations

Instructions" (WHC 1989b). Should deviations from established EII be required to accommodate unforseen field situations, they may be authorized by the Field Team Leader in accordance with the requirements of EII 1.4, "Deviation from Environmental Investigations Instructions" (WHC 1989b). Documentation, review, and disposition of instruction change authorization forms are defined within EII 1.4. Other types of document change requests shall be completed as required by the Westinghouse Hanford procedures governing their preparation and revision.

\subsection{SAMPLE CUSTODY}

All samples obtained during the course of this investigation shall be controlled as required by EII 5.1 "Chain of Custody," (WHC 1989) from the point of origin to the analytical laboratory. Laboratory chain-of-custody procedures shall be reviewed and approved as required by Westinghouse Hanford procurement control procedures as noted in Section 4.1, and shall ensure the maintenance of sample integrity and identification throughout the analytical process. At the direction of the Technical Lead, requirements for return of residual sample materials after completion of analysis shall be defined in accordance with those procedures defined in the procurement documentation to subcontractor or participant contractor laboratories. Chain-of-custody forms shall be initiated for returned residual samples as required by the approved procedures applicable within the participating laboratory. Results of analyses shall be traceable to original samples through the unique code or identifier specified in Section 4.0 above. All results of analyses shall be controlled as permanent project quality records as required by $Q R 17.0$, "Quality Assurance Records" (WHC 1989a) and EII 1.6, "Records Management" (WHC 1989b).

\subsection{CALIBRATION PROCEDURES}

Calibration of all Westinghouse Hanford measuring and test equipment, whether in existing inventory or purchased for this investigation, shall be controlled as required by QR 12.0, "Control of Measuring and Test Equipment"; QI 12.1, "Acquisition and Calibration of Portable Measuring and Test

Equipment" (WHC 1989a); QI 12.2, "Measuring and Test Equipment Calibration by User" (WHC 1989a); and/Or EII 3.1, "User Calibration of Health and Safety Measuring and Test Equipment" (WHC 1989b). Routine operational checks for Westinghouse Hanford field equipment shall be as defined within applicable EII or procedures; similar information shall be provided in Westinghouse Hanford-approved participant contractor or subcontractor procedures. 
Calibration of Westinghouse Hanford, participant contractor, or subcontractor laboritory analytical equipment shall be as defined by applicable standard analytical methods, subject to Westinghouse Hanford review and approval.

\subsection{ANALYTICAL PROCEDURES}

Analytical methods or procedures based on the reference methods identified in Table G-1 and Section 3.0 shall be selected or developed and approved before use in compliance with appropriate Westinghouse Hanford procedure and/or procurement control requirements as noted in Section 4.1.

\subsection{DATA REDUCTION, VALIDATION, AND REPORTING}

\subsection{DATA REDUCTION AND DATA PACKAGE PREPARATION}

All analytical laboratories shall be responsible for preparing a report summarizing the results of analysis and for preparing a detailed data package that includes all information necessary to perform data validation to the extent indicated by the minimum requirements of Section 8.2. Data summary report format and data package content shall be defined in procurement documentation subject to Westinghouse Hanford review and approval as noted in Section 4.1 above. At a minimum, laboratory data packages shall include the following:

- Sample receipt and tracking documentation, including identification of the organization and individuals performing the analysis, the names and signatures of the responsible analysts, sample holding time requirements, references to applicable chain-of-custody procedures, and the dates of sample receipt, extraction, and analysis

- Instrument calibration documentation, including equipment type and model, with continuing calibration data for the time period in which the analysis was performed

- Quality control data, as appropriate for the methods used, including matrix spike/matrix spike duplicate data, recovery percentages, precision data, laboratory blank data, and identification of any nonconformances that may have affected the measurement system of the laboratory during the time period in which the analysis was performed

- The analytical results or data deliverables, including reduced data, reduction formulas or algorithms, and identification of data outliers or deficiencies. 
DOE/RL-90-49

Revision 0

Other supporting information, such as initial calibration data, reconstructed ion chromatographs, spectrograms, traffic reports, and raw data, need not be included in the submittal of individual data packages unless specifically requested by the Technical Lead or the OSM. However, all sample data, shall be retained by the analytical laboratory and made available for systems or program audit purposes upon request by Westinghouse Hanford, the DOE-RL, or regulatory agency representatives (Section 10.0). Such data shall be retained by the analytical laboratory through the duration of their contractual statement of work, at which point it shall be turned over to Westinghouse Hanford for archiving.

The completed data package shall be reviewed and approved by the analytical laboratory's QA Manager before submittal to OSM for validation as discussed in Section 8.2 . The requirements of this section shall be included in procurement documentation or work orders, as appropriate, in compliance with the standard Westinghouse Hanford procurement control procedures referenced in Section 4.1.

\subsection{VALIDATION}

Validation of the completed data package shall be performed by qualified Westinghouse Hanford OSM personnel. Validation requirements shall be defined within approved OSM data validation procedures, but at a minimum shall require the checks as defined within this section.

For inorganic analyses, validation reports shall be prepared documenting validation of the following areas, as recommended in Laboratory Data Validation Functional Guidelines for Evaluating Inorganics Analyses (EPA 1988):

- Data summary narrative

- Sample holding times

- Continuing calibration requirements

- Method blank sample requirements

- Interference check sample requirements

- Laboratory control sample requirements

- Duplicate sample analysis

- Matrix spike sample requirements

- Atomic absorption quality control requirements

- Inductively coupled plasma serial dilution requirements

- Overall data assessment requirements. 
DOE/RL-90-49

Revision 0

\subsection{FINAL REVIEW AND RECORDS MANAGEMENT CONSIDERATIONS}

All validation reports and supporting analytical data packages shall be subjected to a final technical review by a qualified reviewer at the direction of the Westinghouse Hanford Technical Lead, before submittal to regulatory agencies or inclusion in reports or technical memoranda. All validation reports, data packages, and review comments shall be retained as permanent project quality records in compliance with EII 1.6, "Records Management" (WHC 1989b) and QA 17.0, "Quality Assurance Records" (WHC 1989a).

\subsection{INTERNAL QUALITY CONTROL}

All analytical samples shall be subject to in-process quality control measures in both the field and laboratory. Unless superseded by specific directions provided in Chapter 7.0 of the 4843 AMSF closure plan, the following minimum field quality control requirements apply. These requirements are adapted from Test Methods for Evaluating Solid Waste, (SW-846) (EPA 1986), as modified by the proposed rule changes included in the Federal Register, Volume 54, No. 13 (EPA 1989). Definitions of the sample types can be found in the glossary.

- Field duplicate samples. Field duplicate samples are generally used to verify the repeatability or reproducibility of analytical data. For each shift of sampling activity under an individual sampling subtask, a minimum of 5 percent of the total collected samples shall be duplicated.

- Split samples. At the Technical Lead's direction, the field or field duplicate sample will be split in the field and sent to an alternative laboratory as a performance audit of the primary laboratory.

Frequency shall meet the minimum schedule requirements of Section 10.0.

- Field blanks. Field blanks are used as a check for possible contamination originating with the reagent or the sampling environment, and are normally collected once each day.

- Equipment blanks. Equipment blanks are used to verify the adequacy of sampling equipment decontamination procedures, and are collected once each day.

- Trip blanks. Trip blanks shall be returned unopened to the laboratory, and are prepared as a check on possible contamination originating from container preparation methods, shipment, handling, storage, or site conditions. In compliance with standard Westinghouse Hanford procurement procedures, requirements for trip blank preparation shall be included in procurement documents of work orders to the sample container supplier and/or preparer. Trip blanks should be collected daily. 
DOE/RL-90-49

Revision 0

The internal quality control checks performed by analytical laboratories laboratory analyses shal1 meet the following minimum requirements:

- Matrix spiked and matrix spiked duplicate samples. Matrix spiked and matrix spiked duplicate samples require the addition of a known quantity of a representative analyte of interest to the sample as a measure of recovery percentage. The spike should be made in a replicate of the field duplicate samples. Spike compound selection, quantities, and concentrations shall be described in the laboratory's analytical procedures. One sample shall be spiked per analytical batch, or once every 20 samples, whichever is greater.

- Quality control reference samples. A quality control reference sample shall be prepared from an independent standard at a concentration other than that used for calibration, but within the calibration range. Reference samples are required as an independent check on analytical technique and methodology, and shall be run with every analytical batch, or every 20 samples, whichever is greater.

other requirements specific to laboratory analytical equipment calibration are included in Section 6.0. The minimum requirements of this section shall be invoked in procurement documents or work orders in compliance with standard Westinghouse Hanford procedures as noted in Section 4.1.

\subsection{PERformance AND SYSTEM AUdits}

Performance, system, and program audits are scheduled to begin early in the execution of this closure plan and continue through completion. Collectively, the audits address quality affecting activities that include, but are not 1 imited to, measurement system accuracy, intramural and extramural analytical laboratory services, field activities, data collection, processing, validation, and management.

Performance audits of the accuracy of laboratory analyses are implemented in accordance with Standard Operating Procedure EII 1.12 "Laboratory Analysis Performance Audits." System audit requirements are implemented in accordance with Standard Operating Procedure QI 10.4, "Surveillance" (WHC 1989a). Surveillances will be performed regularly throughout the course of the closure plan activities. Additional performance and system "surveillances" may be scheduled as a consequence of corrective action requirements, or may be performed upon request. All quality affecting activities are subject to surveillance.

All aspects of the 4843 AMSF closure plan activities also will be evaluated as part of routine environmental restoration program wide QA audits under the Standard Operating Procedure requirements of WHC-CM-4-2 (WHC 1989a). 
DOE/RL-90-49

Revision 0

Program audits shall be conducted in accordance with QR 18.0, "Audits," QI 18.1 "Audit Programming and Scheduling," and QI 18.2, "Planning, Performing, Reporting, and Follow-up of Quality Audits" by auditors qualified in accordance with QI 2.5, "Qualification of Quality Assurance Personnel" (WHC 1989a).

\subsection{PREVENTIVE MAINTENANCE}

A11 measurement and testing equipment used in the field and 1aboratory that directly affects the quality of the analytical data shall be subject to preventive maintenance measures that ensure minimization of measurement system downtime. Field equipment maintenance instructions shall be as defined by the approved procedures governing their use. Laboratories shall be responsible for performing or managing the maintenance of their analytical equipment; maintenance requirements, spare parts lists, and instructions shall be included in individual methods or in laboratory QA plans, subject to Westinghouse Hanford review and approval. When samples are analyzed using the EPA reference methods, the requirements for preventive maintenance of laboratory analytical equipment as defined by the reference method shall apply.

\subsection{DATA ASSESSMENT PROCEDURES}

Test data from this investigation will be assessed as required by Chapter 7.0 of the 4843 AMSF closure plan. Analytical data shall first be compiled and summarized by the laboratory and validated in compliance with approved OSM procedures meeting all minimum requirements of Section 8.0 above.

\subsection{CORRECTIVE ACTION}

Corrective action requests required as a result of surveillance reports, nonconformance reports, or audit activity shall be documented and

dispositioned as required by $Q R$ 16,0, "Corrective Action"; QI 16.1, "Trending/ Trend Analysis"; and QI 16.2, "Corrective Action Reporting," (WHC 1989a).

Primary responsibilities for corrective action resolution are assigned to the Technical Lead and the QA Coordinator. Other measurement systems, procedures, or plan corrections that may be required as a result of routine review processes shall be resolved as required by governing procedures or shall be referred to the Technical Lead for resolution. Copies of all surveillance, nonconformance, audit, and corrective action documentation shall be routed to the project QA records upon completion or closure. 
DOE/RL-90-49

Revision 0

\subsection{QUALITY ASSURANCE REPORTS}

As statedapreviously in Sections 10.0 and 13.0, project activities shall be regularly assessed by auditing and surveillance processes. Surveillance, nonconformance, audit, and corrective action documentation shall be routed to the project quality records upon completion or closure of the activity. A report summarizing al1 audit, surveillance, and instruction change authorization activity (Section 4.4 ), as well as any associated corrective actions, shall be prepared at the completion of the activity. The report(s) shall be submitted to the Technical Lead for incorporation into the final report prepared at the end of the investigation. The final report shall include an assessment of the overall adequacy of the total measurement system with regard to the data quality objectives of the investigation.

\subsection{REFERENCES}

Comprehensive Environmental Response, Compensation and Liability Act of 1980, as amended, 42 USC 9601 et seq.

Ecology, et a1., 1990, Hanford Federal Facility Agreement and Consent Order, Vo1. 1 and 2, Washington State Department of Ecology, U.S. Environmental Protection Agency, and U.S. Department of Energy, Richland, Washington.

EPA, 1986, Test Methods for Evaluating Solid Wastes, SW-846, Third Edition U.S. Environmental Protection Agency/Office of Solid Waste and Emergency Response, Washington, Washington, D.C.

EPA, 1987, Data Quality Objectives for Remedial Response Activities: Volume I, Development Process, EPA/540/6-87/003, Office of Emergency and Remedial Response and Office of Waste Programs Enforcement, U.S. Environmental Protection Agency, Washington, D.C.

EPA, 1988, Laboratory Data Validation Functional Guidelines for Evaluating Inorganics Analyses, Hazardous Site Evaluation Division,

U.S. Environmental Protection Agency, Washington, D.C.

EPA, 1989, "Hazardous Waste Management System; Testing and Monitoring Activities (Proposed Rule)"; in Federal Register, Vol. 54, No. 13, pp 3212-3228.

WHC, 1989a, Westinghouse Hanford Company Quality Assurance Manual, WHC-CM-4-2, Westinghouse Hanford Company, Richland, Washington.

WHC, 1989b, Environmental Investigations and Site Characterization Manual, WHC-CM-7-7, Westinghouse Hanford Company, Richland, Washington. 
DOE/RL-90-49

Revision 0

1 WHC, 1990, Environmental Engineering, Technology, and Permitting Function

2 Quality Assurance Program Plan, WHC-EP-0383, Westinghouse Hanford

3 Company, Richland, Washington. 
DOE/RL-90-49

Revision 0

\section{DISTRIBUTION}

Number of copies

ONSITE

17

U.S. Department of Energy-

Richland Operations Office

E. A. Bracken (15)

DOE-RL Reading Room (2)

A5-19

Al-65

21

Westinghouse Hanford Company

C. K. Disibio

B3-03

J. R. Freeman-Pollard

H4-55

L. A. Kemp

M. J. La Barge

S. M. Price

A. L. Prignano (4)

L. W. Roberts

F. A. Ruck, III

L. D. Schwartz

J. A. Seamans

L. W. Vance

B. D. Williamson

Central Files

EDMC (3)

Information Release

H4-17

B2-19

H4-57

$\mathrm{H} 4-57$

T3-28

H4-57

L6-40

N1-36

$\mathrm{H} 4-16$

B3-15

L8-15

H4-22

Administration Office (2)

H4-17 

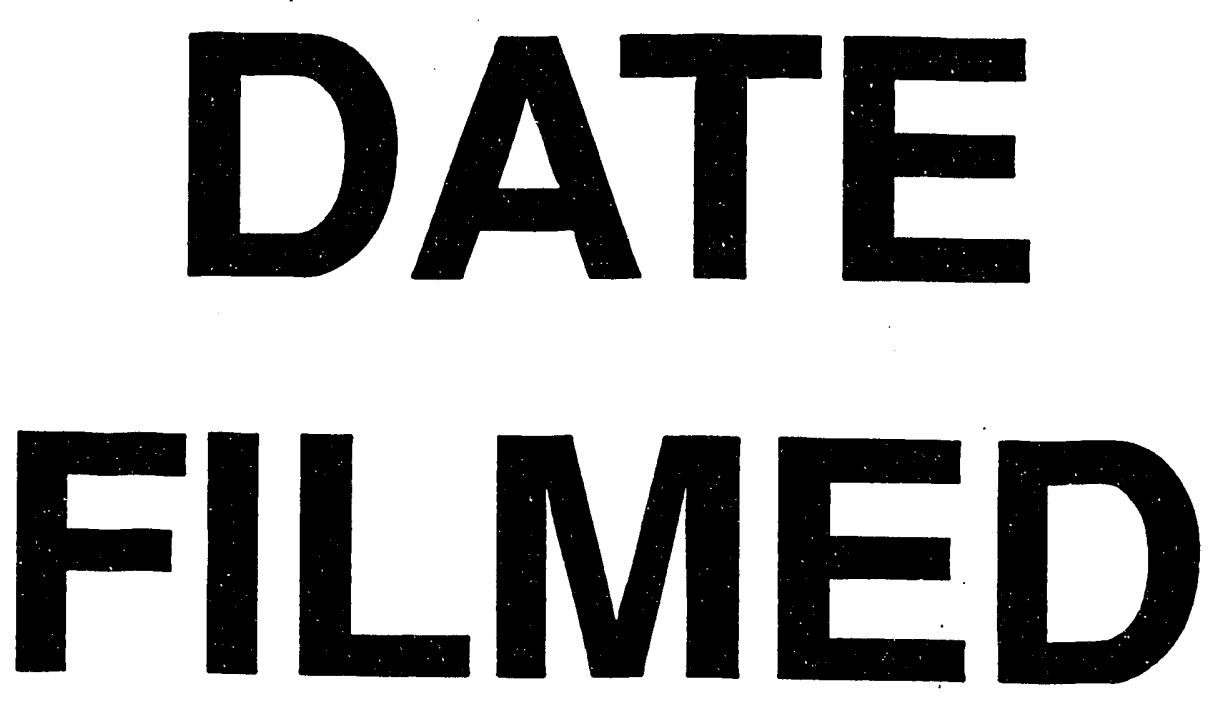

$9 / 28 / 93$
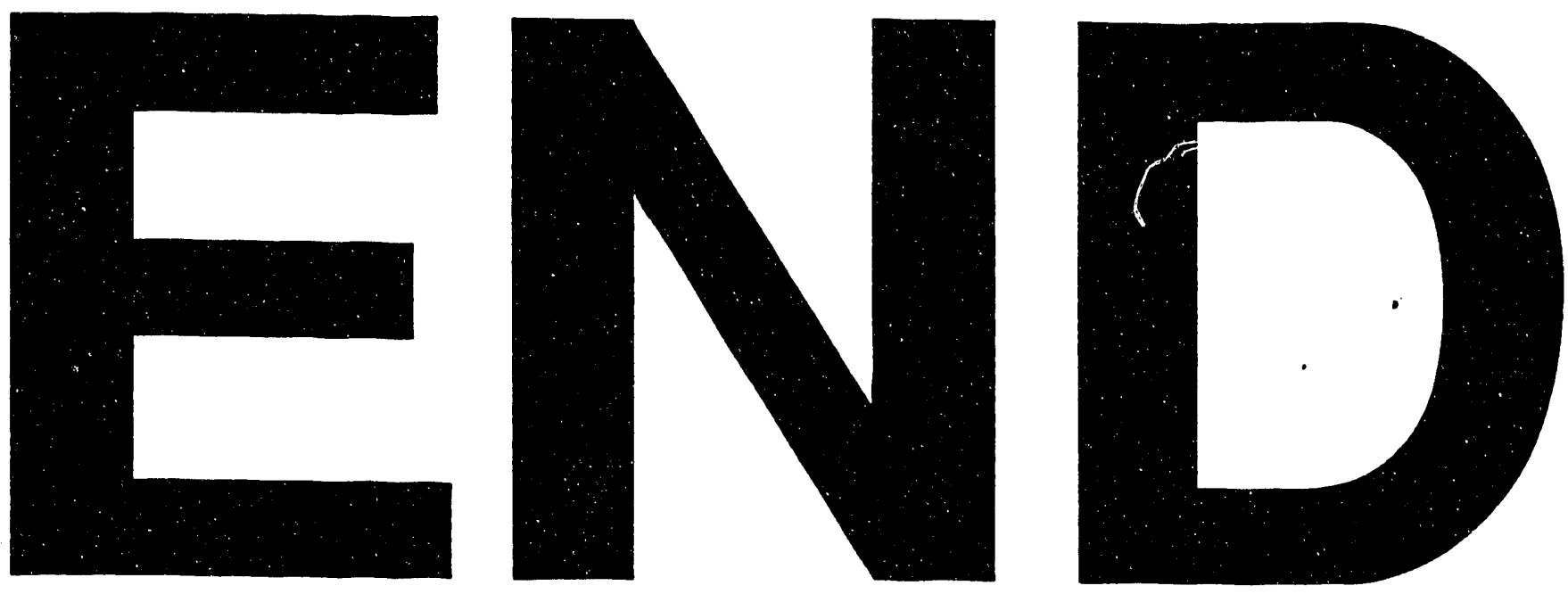
